Performance

No.1795

September 2021

\title{
Organizational capacity and profit shifting
}

Katarzyna Bilicka

Daniela Scur 


\section{Abstract}

This paper analyses the effect of a firm's organizational capacity on the reported profitability of multinational enterprises (MNEs). Better organizational practices improve productivity and the potential taxable profits of firms. However, higher adoption of these practices may also enable more efficient allocation of profits across tax jurisdictions, lowering actual taxable profits. We present new evidence that MNE subsidiaries with better such practices, when located in high-tax countries, report significantly lower profits and have a higher incidence of bunching around zero returns on assets. We show these results are driven by patterns consistent with profit-shifting behavior. Further, using an event study design, we find that firms with better practices are more responsive to corporate tax rate changes. Our results suggest organizational capacity, especially monitoring-related practices, enables firms to engage in shifting profits away from their high-tax subsidiaries.

Key words: profit shifting, organizational capacity, monitoring practices, multinationals JEL: H26; H32; M11; M2

We thank Nick Bloom, Nathan Canen, Raj Chetty, Michael Devereux, Tim Dowd, Andreas Haufler, Peter Egger, Antoine Ferey, Claudio Ferraz, Silke Forbes, Bob Gibbons, Maria Guadalupe, Anna Gumpert, Jim Hines, Kristina McElheran, Jacob Miethe, Andrea Prat, Raffaella Sadun, André Seidel, John Van Reenen, Mike Waldman and Erina Ytsma for their comments. Further thanks to the participants of the NBER Summer Institute 2021, NBER Productivity Innovation and Entrepreneurship 2021 spring meeting, NBER Organizational Economics 2020 fall meeting, SIOE 2020, Econometric Society World Congress 2020, IIPF 2019 Annual Congress, EEA 2019 Annual meeting, NTA 2019 Annual meeting, Empirical Management Conference 2019 and seminar participants at MIT, UC Berkeley, Cornell, Oxford, NYU, CMU, Utah, SSE, Bath, Groningen, LMU Munich, Mannheim and UQAM for their helpful suggestions. We gratefully acknowledge funding from the Cornell Centre for Social Sciences. We would also like to thank Ali Abbas and Qiwei He for excellent research assistance.

Katarzyna Bilicka, Utah State University, NBER and CEPR. Daniela Scur, Cornell University, CEPR and Centre for Economic Performance, London School of Economics.

This paper was produced as part of the Centre's Growth Programme. The Centre for Economic Performance is financed by the Economic and Social Research Council.

Published by

Centre for Economic Performance

London School of Economics and Political Science

Houghton Street

London WC2A 2AE

All rights reserved. No part of this publication may be reproduced, stored in a retrieval system or transmitted in any form or by any means without the prior permission in writing of the publisher nor be issued to the public or circulated in any form other than that in which it is published.

Requests for permission to reproduce any article or part of the Working Paper should be sent to the editor at the above address.

(c) K. Bilicka and D. Scur, submitted 2021. 


\section{Introduction}

Understanding heterogeneity in firm performance is one of the oldest topics in economics, and the unique role of managers is highlighted in the earliest papers (Walker; 1887). Decades of empirical work have consistently shown a clear and significant positive relationship between good managers, good management and productivity (e.g., Bandiera et al.; 2015; Bloom et al.; 2013, 2016; Dessein and Prat; 2019; Ichniowski et al.; 1997), but the relationship with profitability is less straightforward (e.g., Adams et al.; 2005; Armstrong et al.; 2012; Bloom, Genakos, Sadun and Van Reenen; 2012; Dyreng et al.; 2010; Koester et al.; 2017). While productivity is a more direct measure of production effectiveness, profitability measures such as returns on assets (ROA) - inherently include strategic decisions on reporting and may be more reflective of aggressive accounting practices than actual performance (Bertrand and Schoar; 2003).

In this paper, we explore the relationship between organizational capacity and firm profitability across countries with different tax rates, and propose that this capacity is an important enabler of legal tax avoidance by multinationals (MNEs). ${ }^{2}$ The literature on legal tax avoidance (and, in particular, profit shifting) has primarily focused on the characteristics of individual managers to explain a firm's propensity to engage in these activities (Armstrong et al.; 2012; Desai and Dharmapala; 2006; Dyreng et al.; 2010; Koester et al.; 2017). Other than firm size, studies have found few other firm characteristics to be systematically linked with such practices (Bilicka; 2019). We build a unique dataset of manufacturing multinational enterprises (MNEs) across 21 countries, matching management practices data to fifteen years of detailed firm accounts information and classify the tax regimes the firms operate in, as well as their levels of aggressive accounting practices. ${ }^{3}$

We have three main sets of results. First, we classify firms based on the location of their operations; for every year between 2004 and 2018, we identify whether they operate their production subsidiaries in low- or high-statutory tax rate countries. We find that the well-documented average positive relationship between management practices and firm profitability only holds in low-tax countries, while the relationship with productivity holds in both high- and low-tax jurisdictions. ${ }^{4}$ This suggests that MNE subsidiaries adopting "good"

\footnotetext{
${ }^{2}$ This paper focuses on legal tax avoidance and profit shifting practices, not illegal tax evasion.

${ }^{3}$ We focus our analysis on multinational corporations (MNEs) for three reasons: first, they are able to shift profits abroad, unlike domestic firms. Second, due to their international nature and size, they are a reasonably comparable group with publicly available data. Third, MNEs often span several jurisdictions, allowing us to exploit variation in statutory tax rates across jurisdictions and time.

${ }^{4}$ For evidence on the positive relationship between management and firm performance and the average positive relationship with firm profitability, see for example: Bloom et al. (2013, 2014); Giorcelli (2019).
} 
management practices generate higher revenues that, on average, do not translate into higher reported profits outside of lower-tax jurisdictions. ${ }^{5}$ This pattern persists in the sample of firms where we observe management practices for multiple subsidiaries within the same MNE, and it is not present when we consider the sample including only domestic firms. Using an event study design exploiting tax rate cuts across countries, we find that MNE subsidiaries respond to tax cuts by reporting higher profits in jurisdictions that enact those cuts, and that this increased reporting is driven by the better managed firms. ${ }^{6}$

Second, we show the patterns we observe are consistent with organizational capacity enabling firms to shift profits more effectively across jurisdictions. A main challenge in studying profit shifting practices is that these activities are not directly observable to firm outsiders. However, there are certain firm behaviors that are indicative of "aggressive avoidance." The measures we use include firms that have large disparities between their reported financial and taxable profits (large book-tax differences) (Desai; 2003; Desai and Dharmapala; 2006, 2009); MNEs that have tax haven subsidiaries or headquarters in their ownership tree (Desai et al.; 2006; Dowd et al.; 2017; Gumpert et al.; 2016; Hines and Rice; 1994); and firms that report ROAs near zero (Bilicka; 2019; Johannesen et al.; 2020). We show that the patterns we uncover in reporting practices of better managed firms are driven by those that exhibit these "aggressive" behaviors. We rule out real productivity differences and local investment incentives as alternative possible channels driving our results.

To explain how better management could enable profit shifting, we propose a simple framework where firms adopting better management practices have more tractable and predictable production plans and we use the detailed plant-level data on management practices to iteratively consider each practice. We document that the set of practices related to monitoring production are most consistently correlated with lower profitability in high-tax countries. Broadly, practices linked to tractability and predictability of production, as well as firm-related incentives (rather than plant-specific incentives) are most likely to enable profit shifting.

Our findings are distinct from, though complementary to, the literature on the effect of individual managers and manager-specific qualities on profit shifting. While this literature focuses on the characteristics of individuals who are in the position of manager, we focus on the organizational structure those managers operate in. There could certainly be an

\footnotetext{
${ }^{5}$ We use "good management" here to mean a higher score in the World Management Survey measure, which has been linked to better firm productivity, product quality, average profitability, survival and innovation. See Scur et al. (2021) for a survey. We describe this measure in detail in the Data section.

${ }^{6}$ Fuest et al. (2018) and Serrato and Zidar (2016) use a similar design to consider the effects of corporate tax rate cuts on wages.
} 
interaction effect: for any given level of organizational capacity, a good manager can be better able to take advantage of it relative to a bad manager. But we propose that even a good manager will not be able to shift profits effectively without the appropriate structures in place. Empirically, we show that the link between organizational capacity and profit shifting does not vary substantially across firms with different levels of individual manager quality (proxied by executive compensation). We do find that, however, that results are driven by MNEs with more centralized decision-making. Thus, the effects of organizational capacity on profit shifting are of first order importance.

Our paper contributes to the literatures on profit shifting and the effect of management practices on firm performance. First, the profit shifting literature finds that large MNEs with links to tax havens tend to report low profits in high-tax countries (Desai et al.; 2006; Dowd et al.; 2017; Gumpert et al.; 2016; Hines and Rice; 1994), but beyond firm size there is scant evidence on what characteristics enable profit shifting (Bilicka; 2019; Wier and Reynolds; 2018). There is evidence on a variety of strategies that firms can use to avoid paying corporate taxes, such as debt shifting (Desai et al.; 2004; Huizinga et al.; 2008), transfer pricing (Cristea and Nguyen; 2016; Davies et al.; 2018) and intellectual property location (Dischinger and Riedel; 2011). Our paper provides a mechanism that enables firms to use these various tools more (or less) effectively. Second, there is a vast literature on the strong positive relationship (correlational and causal) between these good management practices and firm performance. This relationship is consistent across sectors and countries. ${ }^{7}$ More recently, studies have started to focus on the relationship between these practices and outcomes other than productivity, such as labor flows (Bender et al.; 2018; Cornwell et al.; 2021) and inequality (Bloom, Ohlmacher and Tello-Trillo; 2020). We contribute to this new set of outcomes, providing the first evidence of the relationship between these management practices and tax planning activities.

This question has substantial policy relevance from a micro as well as macro perspective. At the micro level, management upgrading projects have come into vogue motivated by the potential of large gains in productivity. ${ }^{8}$ As governments tax firm profits rather than productivity, the relationship between better management and potentially lower corporate tax revenues matters for the cost-benefit calculus. From a macro-perspective, our results suggest

\footnotetext{
${ }^{7}$ See, for example Bloom, Genakos, Sadun and Van Reenen (2012); Bloom, Lemos, Sadun and Van Reenen (2020); Bloom and Van Reenen (2007); Lemos et al. (2021) and Scur et al. (2021) for a summary.

${ }^{8}$ For example, since 2014 there were 15 operations projects relating to improving management practices "funded" by the World Bank, amounting to 2.6 billion dollars in direct lending. There were also a further 26 technical assistance, advisory services and knowledge management projects (without specific costs attached to them). Knack et al. (2020) reviews the relevance of the World Bank's non-lending instruments.
} 
that heterogeneity in firm management quality can mediate the effectiveness of corporate tax cuts and should be taken in to account when devising such policies.

\section{Conceptual framework}

In this section we discuss the conceptual framework underpinning our empirical investigation. In short, we propose that MNE subsidiaries need good organizational capacity to enable effective tax planning, including local tax minimization and shifting of "excess" profits across subsidiaries. We consider that a firm has "good" organizational capacity (henceforth, good management) when they use, on average, a set of mostly formal management practices in their day-to-day operations of their subsidiaries. ${ }^{9}$ To minimize their tax burden, firms will first aim to lower their local tax liabilities as much as possible using, for example, investment incentives and local tax law provisions particular to their operation. Once firms exhaust local options, they will consider whether and how much of their excess profits to move to other jurisdictions under the MNEs global operations. To provide context, we briefly outline the most common methods of profit shifting used by MNEs, and subsequently propose how organizational capacity can influence a firm's ability to use them.

\subsection{Methods of profit shifting}

Profit shifting happens via three main types of actions: debt shifting, transfer pricing and patent location. For debt shifting, a subsidiary of an MNE located in high-tax country borrows funds from a subsidiary located in low-tax country. Interest payments on this debt are deductible against taxable profits, reducing the tax liability in the high-tax country. The interest payments accrue to the subsidiary in the low-tax country, being taxed at the lower rate and reducing the overall tax liability of the MNE. In our context, predictable income streams enable effective debt shifting as lending to a subsidiary with a clear profit forecast allows the tax planner to predict the appropriate amount of debt to reduce the overall tax liability to near zero, but not as far as leaving the subsidiary reporting negative profits. It is important to stay near zero and avoid being too far into the negative, as that can be

\footnotetext{
9 "Formal management practices" here implies that there is a clearly determined, formal process in place that governs the day-to-day operations of the plant rather than the manager simply running things in an ad-hoc manner (that is, informally). For example, we would consider a firm that has a specific set of key performance indicators that are measured weekly a "formal" practice, and a loose set of indicators that a manager tends to track whenever they feel is necessary an "informal" practice. Section 3 describes the data in more detail, including further examples.
} 
problematic for several reasons. First, firms they care about shareholder perception and prefer subsidiaries not to incur losses, especially if they are in fact involved in profitable activities. There is also a limit on the amount that low-tax subsidiaries can lend, and too much debt could also increase the likelihood of risky investments and result in potential bankruptcy. Having formalized processes that outline a set of production indicators to be regularly tracked and monitored, as well as clear and linked targets across the firm and divisions allows for such planning to take place and enables potential short-term adjustments when necessary.

For transfer pricing, a subsidiary located in high-tax country buys intermediate products from subsidiaries in low-tax countries at prices that are higher than market prices, reducing profits by increasing costs. The low-tax seller earns revenue from the sale which is taxed at lower rates. This strategy relies on mis-pricing goods (generally inflating) relative to their market value and is best achieved using goods that are difficult to price on third party markets, such as intangibles. This is a popular activity because it is hard for governments to legally detect, but the "mis-prices" must be relatively fixed in the short-run. Too much change in the prices of the same intangibles year-on-year raises red flags with government

auditors. For patent location, MNEs can locate their patents in low-tax subsidiaries, such that any profits earned on those patents will be taxed at lower rates. Further, royalties for the use of those patents by other subsidiaries will also be taxed at lower tax rates, while the cost of paying the royalties will be deducted against profits in high-tax countries. In our context, mis-pricing of goods relies on knowing production levels and feasibility of trade between locations, while determining the amount of royalty payments is easier when one can track firm productivity.

There is no dataset available that would allow for clear identification of which strategies firms are using, as some of these practices remain opaque even within firms. As our framework is consistent with profit shifting decisions using any (or all) the above strategies, we do not need to identify between them but simply need to understand that these are the potential activities that firms engage in to shift profits, and that better organizational capacity affects the extent to which firms are capable of executing these actions.

\subsection{Organizational capacity and tax planning activities}

We propose that predictability of production, such as being able to request and receive information on accurate production and profits forecasts for different subsidiaries, allows the HQ manager to plan tax liabilities accordingly. Tractability of production, such as having 
clear production plans with reasonable timelines enables the HQ manager to request specific changes to subsidiary production plans to fit specific target requirements. Having those figures available allows the HQ manager to make production targets and profit reallocation decisions between subsidiaries for the current year as well as plan for the following years. The HQ managers make decisions about profit allocations, while plant-level managers make decisions related to production efficiencies. As such, it is unlikely that plant-level managers will implement better management practices with the exclusive goal of enabling profit shifting and we do not expect reverse causality to be an issue in this setting.

Our framework implies that better management, via more tractable and predictable production, enables firms to carry out effective tax planning and thus shift a larger share of profits, as they seek to maximize their after-tax profits. We propose that the potential effect of management on profit shifting activities is causal in the same spirit as the effect of management on productivity is causal. For example, in Bloom et al. (2013) a random sample of firms were provided with professional management consulting and the authors find a causal relationship between better management and firm performance, as the treated firms experienced an increase of $13 \%$ in productivity within the first year. This improvement in performance naturally happened via the managers who implemented the changes and the employees who became more efficient in their production activities. In our context, better management would affect profit shifting in a similar manner, in that the shifting happens via the HQ managers who decide on the allocation of profits but it is the existence of the good management structures that make such reallocation decisions possible. To be sure, this is not to imply that we draw causal inference from the set of correlational results presented in this paper, but rather to provide clarity on how we perceive the chain of causality in this context.

Further, our framework is distinct from the literature that considers the effect of individual managers, or manager-specific quality on profit shifting (Armstrong et al.; 2015; Desai and Dharmapala; 2006; Koester et al.; 2017). This literature implicitly assumes that when a decision is made at the HQ, it can be enacted. We propose that firm heterogeneity in management quality at the subsidiary level can significantly impact the operationalization of profit shifting strategies. While there could be an interaction effect such that better managers still do better with a given level of organizational structure, even a good manager will not be able to shift profits effectively without a minimum level of organizational capacity.

Finally, while profit shifting decisions are made by managers at the HQ and not by individual subsidiary managers, HQ can still adopt local incentive policies that are aligned with their profit allocation goals. For example, HQ can choose to link manager bonuses to 
MNE performance rather than subsidiary performance. As such, we expect that firms with higher degrees of centralized decision-making are also more likely to be able to engage in profit shifting behavior. Thus, we expect that the effect that organization capacity has on profit shifting is still of first order importance.

\section{Data}

We use two main data sources for this paper: the World Management Survey (WMS), a random sample of mid- to large-sized manufacturers from 21 countries, and Bureau van Dijk's Orbis, a provider of firm-level accounting data. We describe each in turn below. Our primary analysis sample starts with all MNE subsidiaries in the WMS sample for which we have financial data, including at least profit and loss before taxes and total assets. This includes 1,783 subsidiaries, belonging to 1,388 unique parent MNEs and yields 16,076 subsidiary-year observations between 2004 and 2018. ${ }^{10}$ For a series of robustness checks, we (a) include the set of domestic firm subsidiaries in the WMS located in the set of countries of the primary analysis sample (yielding 2,458 subsidiaries and 16,446 subsidiary-year observations between 2010-2018); ${ }^{11}$ (b) include the full set of subsidiaries belonging to a MNE that has at least one observation in the WMS sample (yielding 79,949 subsidiaries and 537,508 subsidiaryyear observations). For our event study analysis, we restrict the latter "extended" sample to only subsidiaries in countries that experienced a single tax rate reduction within the sample period. This yields a sample of over 17,581 subsidiaries with over 115,721 subsidiary-year observations. Table I reports summary statistics across all firm-years for the baseline and event study samples.

\subsection{Management data: World Management Survey}

To measure the level of adoption of management practices in a firm we use the World Management Survey, a project that has systematically collected data on the adoption of structured management practices in firms since 2004. The WMS focuses on medium- and large-sized

\footnotetext{
${ }^{10}$ We require unconsolidated subsidiary level data to analyze differences in the allocation of profits between firm subsidiaries. Thus, we are unable to use Compustat for the US, which includes consolidated level data.

${ }^{11}$ The domestic firms sample includes only firms located in the countries included in the baseline MNE sample (see Figure I for a list of countries). While the WMS has a larger set of domestic firms in its full sample, domestic firms do not face the same reporting requirements as multinationals and thus only a small set have publicly available financial data. A more thorough analysis of tax reporting patterns in domestic firms requires access to country-specific administrative tax records, which we explore in future work.
} 
firms, drawing a random sample of firms with employment of between 50 and 5,000 workers. The WMS methodology, first described in Bloom and Van Reenen (2007), employs a double-blind, interview-based evaluating tool that defines and scores a set of 18 basic management practices on a scoring grid from one ("little/no formal management practices") to five ("best practice"). The topics covered include adoption of lean manufacturing practices, performance monitoring, target setting and people management (see Table C1 and C2 for the full list of questions and the explanation of the measures).

Measuring management practices: The WMS project systematically collects comparable and time-consistent data on the types of practices used at thousands of manufacturing plants. It uses an interview-based survey tool, where highly trained interviewers engage a middle manager in a semi-structured conversation about the day-to-day practices followed at their establishment. The respondent managers were those who were senior enough in their establishment to have decision powers, but not too senior so as to be detached from the day-to-day running of the establishment. The most common respondent is either the plant general manager or operations manager. The survey is set up as an interview, and the questions although structured, are mostly open-ended so the manager being interviewed is not guided towards what a high or low scoring answer might be. ${ }^{12}$ The method is double blind on the side of the interviewees, but also the interviewers who will not typically know more than the organization's name and phone number in advance. The average WMS response rate is usually between 40 and 50 percent, which is extremely high considering that many firms surveys typically get far lower response rates. ${ }^{13}$

The conversation follows a set of broad practices spanning operations/monitoring, target setting and people/incentive management practices. The WMS does not measure the skills of the manager but rather measures the processes embedded in each managerial practice in place within the establishment. Broadly, the scores for each management topic imply the following: A score between 1 to 2 refers to an establishment with practically no structured management practices or very weak management practices implemented; a score between 2 to 3 refers to an establishment with some informal practices implemented, but these practices consist mostly of a reactive approach to managing the organization; a score between 3 to 4 refers to an establishment that has a good, formal management process in place (though not yet often or consistent enough) and these practices consist mostly a proactive approach to

\footnotetext{
${ }^{12}$ This avoids the manager simply giving the answer she thinks the interviewer wants to hear.

${ }^{13}$ For example, Altig et al. (2020); Ben-David et al. (2013); Bloom, Bunn, Chen, Mizen, Smietanka and Thwaites (2019) where response rates in firm surveys range from $0.1 \%$ to $13 \%$.
} 
managing the organization; a score between 4 to 5 refers to well-defined strong practices in place which are often seen as best practices in the sector.

Defining management indices: Following our framework, we focus on the 12 topics that directly relate to operations management and exclude the questions relating to people management from the primary analysis. We use the term "management" to refer to the index of these 12 operations management questions throughout this paper. These are the practices that relate to the tractability and predictability of production, including monitoring and target-setting practices (such as having key performance indicators that are measured and tracked regularly and related targets that link HQ to shop-floor goals). We use the people management index (and its 6 specific practices) in our discussion of mechanisms.

We build two indices of management: a continuous index with the double-standardized average across the 12 topics, and a binary indicator dividing firms into two groups based on a methodological cutoff of the practices measured. ${ }^{14}$ The indicator takes a value of 1 if the firm scores above 3 on the 1 to 5 scale, or having achieved a minimum level of "formal" management practices, while those with scores below 3 have, at best, an "informal" set of practices. We use the terms good management and formal management interchangeably.

Our primary sample includes only firms that are subsidiaries of MNEs from the WMS sample. They operate in various countries in North America, Europe, Latin America and Asia. The MNE subsidiary scores in our sample range from 1.25 to 4.92 , with the 25 th percentile at 2.9 and the 75 th percentile at 3.75. This suggests that while the average MNEs across the countries tends to have "formal" practices in place, there is still substantial variation in management practices across firms and countries. Figure I reports the distribution of scores across countries, including the corporate tax rate for each country next to the country name. The average management score for firms in high-tax subsidiaries is 3.41 and the score for firms in low-tax subsidiaries is 3.32 (Table I). While this difference is statistically significant, its magnitude is small and, on average, the countries with the lowest average management scores do not also have the lowest corporate tax rates in the sample. This should alleviate the concern that our results could be simply picking up a correlation between more "formal" management and tax rates in high tax-countries. As management practices are sticky, we assume they are mostly constant across years (or, at least maintain their tendency towards mostly formal practices in place). ${ }^{15}$

\footnotetext{
${ }^{14}$ The WMS z-score is computed by standardizing each question, taking the average, and standardizing the average. The binary indicator comes from the methodological cutoff used in the scoring of each question by the WMS interviewers (as in Cornwell et al. (2021)).

${ }^{15}$ For WMS firms with panel data we take the average across years. Unfortunately, the sample size that
} 
Measuring decentralization and managerial incentives: The WMS collects additional information on decentralization and type of manager incentives. There are three decentralization questions that measure at which level a set of key decisions are made for the firm. The three decisions are: (a) new product introductions, (b) sales and marketing, (c) hiring of new full time workers. The scoring follows a 1 (all decisions are taken at HQ) to 5 (plant manager has complete authority over these decisions) scale, where 3 means decisions are equally shared between $\mathrm{HQ}$ and the plant. ${ }^{16}$ We focus on the non-HR decentralization measures ( $a$ and b) and our decentralization measure is an average of the two scores. The survey also collects three variables on specific manager incentives: (i) the average size of managerial bonuses, (ii) the share of the managerial bonus tied to overall company performance and (iii) the share of the managerial bonus that is tied to plant-specific performance.

\subsection{Firm and financial measures}

Profitability, performance and investment measures: From the Orbis dataset, return on assets (ROA) is our preferred measure of firm profitability, as is common in the productivity literature as well as the tax and profit shifting literature. It is defined as profit and losses before taxes divided by total assets. An alternative common outcome variable is the effective tax rate (ETR), which measures the amount of taxes paid relative to a firm's profits. Effective tax rates are often used in profit shifting literature to illustrate how little tax MNEs pay in various jurisdictions relative to the tax rates. We focus our analysis on profitability but report additional results using ETR as an outcome variable in the Appendix. We measure performance using the log of sales per employee. We proxy for investment using the annual growth rate of fixed assets.

\section{Aggressiveness: book-tax differences, tax havens and bunching near zero ROA} We use three proxies for aggressive tax avoidance behavior. Our first proxy follows the most commonly used approach and uses the size of book-tax difference (BTD), which measures the difference between pre-tax book earnings and taxable income. The literature has linked this measure with tax-planning activities of MNEs, and in particular Manzon and Plesko (2002) show that approximated measures of demand for tax shelters help explain the variation in BTDs across firms. These measures have been subsequently used in the literature to approximate for aggressive tax planning. Desai and Dharmapala (2006) show that increases

includes panel data is not large enough to allow us to look at changes in management.

${ }^{16}$ This measure has been validated and used in other work (Aghion et al.; 2021; Bloom, Sadun and Van Reenen; 2012). 
in incentive compensation tend to reduce the level of tax sheltering, Desai and Dharmapala (2009) show that the effect of tax avoidance on firm value is a function of firm governance. Desai (2003) points out further that the size of BTDs is related to managerial motives associated with earnings management. Thus, BTDs have been shown to be reliable proxies for both tax sheltering and earnings management and are thus an appropriate tool to use in the context of analyzing the relationship between management and tax planning practices. ${ }^{17}$

We calculate BTDs following the literature and subtract from the pre-tax profits the current tax expense multiplied by the corporate tax rate. We calculate the size of that difference for each firm, adjusting for deferred taxes where firms report them, to create permanent book tax differences. We then scale the size of this difference by firm's total assets and classify firms with larger than median BTDs as more likely to be aggressive tax avoiders and those with below median BTDs as likely to be non-aggressive avoiders. ${ }^{18}$

A second proxy for aggressive tax avoidance is the use of tax havens by multinational firms. Gumpert et al. (2016); Hines and Rice (1994) show that having a tax haven in the firm structure signifies behaviour consistent with more aggressive profit shifting. Under this definition, we classify a firm as being aggressive when an MNE has at least one tax haven subsidiary (or HQ) in the firm ownership tree. Unlike BTD, a firm level proxy for tax aggressiveness, the presence of tax haven is an MNE-level proxy. The majority of MNEs in our sample have tax havens in their firm structure, which is consistent with evidence from previous literature (Desai et al.; 2006; Gumpert et al.; 2016). ${ }^{19}$

Our third proxy follows a relatively recent approach and measures the incidence of bunching around zero reported accounting profits (Bilicka; 2019; Johannesen et al.; 2020). This approach has the benefit of having the lowest data requirements, as it simply uses the distribution of ROAs across the sample. It is also the most straightforward, as the non-parametric analysis does not require additional assumptions to be imposed for the classification of firms. The only assumption is that firms looking to minimize their tax liabilities aim to report as close to zero accounting profits as possible.

\footnotetext{
${ }^{17}$ Erickson et al. (2004) show that traditional BTD measures may not always be a reliable signal of earnings manipulation. BTDs of companies that were committing some tax fraud are not larger than those companies that did not. In the context of this paper, this means that there may be firms that we have classified as non-aggressive avoiders that may be aggressively tax planning. This would bias the findings against our hypothesis.

${ }^{18}$ Our results are not sensitive to choosing alternative thresholds such as classifying the top $25 \%$ as being aggressive avoiders and bottom $25 \%$ as non-aggressive.

${ }^{19}$ While Orbis has poor coverage of financial information for tax haven subsidiaries (Torslov et al.; 2018), we only need to know the existence of such subsidiaries and this more basic information is well reported.
} 
Country-year tax rates: Using the location of the HQ and the subsidiary, we use countryyear corporate statutory tax rates from the Centre for Business Taxation Corporate Tax Database to define high- and low-tax environments. ${ }^{20}$ We define low tax country-year cells as those with statutory corporate tax rates below median in a given year, and high tax country-year cells as those with tax rates above median in a given year. As such, a particular country will be classified as high- or low- tax on an annual basis, depending on their relative tax rate in each year. ${ }^{21}$

\section{Main Results}

\subsection{Management and profitability across tax jurisdictions}

Reduced form evidence The core relationship between management and firm performance has been consistently estimated across and within countries. The correlation between management and profitability is noisier than the correlation between management and operating revenue. Broadly, this suggests that higher turnover generated by firms with better management practices does not necessarily translate into higher reported profitability everywhere. To unpack these patterns, we estimate a reduced form model correlating the ROA of each firm to their management scores, the tax rate in the subsidiary and the interaction between the two:

$$
R O A_{i c t}=\alpha+\beta_{1} M_{i}+\beta_{2} \text { CTRate }_{c t}+\beta_{3} M_{i} \times C T \text { Rate }_{c t}+\gamma_{1} X_{i t}+\eta_{c}+\delta_{t}+\varepsilon_{i c t}
$$

where $R O A_{i t}$ is the returns on assets, $M_{i}$ is management score indicator, CTRate $e_{c t}$ is the statutory corporate tax rate in country $c$ at time $t, X_{i t}$ includes firm level and MNE level controls. $\eta_{c}$ are country fixed effects and $\delta_{t}$ are year fixed effects. Firm level controls include: $\log$ of the number of employees, the log of total assets, and $\log$ of the total number of subsidiaries that MNE has. The management score indicator takes a value of 1 if the firm's score is equal to or above a value of 3 , interpreted as having on average "formal" practices in place. We run the reduced form model across the main set of samples used in this paper

\footnotetext{
${ }^{20}$ For domestic firms, the HQ and any subsidiaries will have a common country of operation by definition. The data is available in the CBT website. For further data documentation see the Eureka website.

${ }^{21}$ For instance, UK had $30 \%$ corporate tax rate in 2007 (above median tax rate), but had gradually lowered its main corporate rate to $19 \%$ in 2017 (below median tax rate).
} 
and report the results in Table II. ${ }^{22}$

Columns (1) to (3) start with the full sample of MNE and domestic firms in the WMS with financial information. Column (1) affirms the positive correlation between formal management and average reported profitability, as well as average higher profitability of MNEs. It also shows that reported profitability is significantly lower in higher-tax countries. Columns (2) includes an interaction between the MNE indicator and the country statutory corporate tax rate, and the coefficient on the interaction is not significantly different from zero, though it is negative. Column (3), in turn, includes an interaction between the formal management indicator and the statutory corporate tax rate, and the coefficient is significant and negative. Taken together, these results suggest that the variation in reported profits across tax jurisdictions are not simply driven by firm ownership, and a firm's organizational capacity explains an important part of this variation.

In Columns (4) and (5) we split the sample into domestic firms (that is, firms that have operations exclusively within the country where they are headquartered) and MNEs. It is clear that the negative interaction coefficient of management and tax rate is driven by MNEs. Specifically, the coefficients in Column (5) imply that if we were to move a firm with formal management from a country at the 25 th percentile value of corporate tax rates (approximately $22 \%$ ) to a country at the 75 th percentile of tax rates (approximately $30 \%$ ), they would report almost 3 percentage points lower ROA in the higher tax country. Figure II depicts the relationship in Column (5) across the distribution of the management score. We plot the local linear regressions of management scores on profitability for MNE subsidiaries in low-tax and high-tax country-years separately. The commonly documented relationship between management and profitability seems to be primarily driven by firms located in lowtax countries, while no discernible pattern exists for firms located in high-tax countries. This stands in stark contrast to the relationship between management and performance, where there is no differential pattern between high- or low-tax countries (Figure B1).

Pooled cross sectional data allows us to observe the location of reported profits, but not the allocation of these profits across jurisdictions within MNEs. This is a concern if firms with formal management are more likely to locate in high- or low-tax jurisdictions for reasons that are unobserved. To partially address this concern, in Column (6) we restrict the sample to the set of MNEs in the WMS sample for which we observe multiple subsidiaries belonging to the

\footnotetext{
${ }^{22}$ We use different standard error clustering across different specifications depending on the sample we use and the variation we explore, following Abadie et al. (2017). We use robust standard errors in the baseline specifications, but cluster at the MNE level when we explore the within-MNE variation.
} 
same MNEs and run a model with MNE fixed effects. ${ }^{23}$ The coefficient on the interaction term between management and tax rate is significantly negative, and we further plot the marginal effects of the continuous measure of management for high- and low-tax subsidiaries in Figure III. The differences are statistically significant beyond a management score of 3 , consistent with Table II.

In all, the correlations in Table II show that only multinational firms with formal management tend to report lower profits in countries with higher tax rates. This pooling across years yields a static analysis of the stock of profit allocated to each type of jurisdiction across all years. However, understanding the dynamics of profit allocation across jurisdictions requires variation in tax rates across time, and the more relevant causal inference question is understanding how management practices enable firms to respond to tax changes.

Event study evidence We exploit the time dimension of our data to consider the effect of a tax rate cut on the allocation of profits across jurisdictions, holding firm management quality constant. This is a reasonable assumption in the short to medium run, as management practices have been shown to be remarkably sticky and organizational change is notoriously difficult (Gibbons and Henderson; 2012). We further assume that if we observe one subsidiary in an MNE with mostly formal practices in place, then all other subsidiaries within the same MNE hold the same tendency. This is not a likely to be a strong assumption, as Bloom, Brynjolfsson, Foster, Jarmin, Patnaik, Saporta-Eksten and Van Reenen (2019) show that the largest variation in management practices is attributed to the differences between firms, rather than across establishments within firms.

Our identifying variation comes from changes in corporate tax rates across jurisdictions in our sample, and our event is defined as a corporate tax rate cut relative to the rate in the previous year for a particular country. A reduction in a tax rate should induce a subsidiary to report more profits in that country (all else equal), and our conceptual framework predicts that this behavior would primarily manifest in better managed firms, as they have the tractability and predictability practices needed to enable an efficient reallocation of profits.

We estimate the following specification:

$$
R O A_{i t}=\alpha+\sum_{\kappa=-4}^{4} \delta_{t} \mathbb{1}[t=\kappa]+\sigma_{1} X_{i t}^{\prime}+\eta_{t}+\epsilon_{i t}
$$

\footnotetext{
${ }^{23}$ This comes with the caveat that the sample includes only 617 firms and 6,084 firm-year observations, representing approximately one-third of the total baseline sample.
} 
where $R O A_{i t}$ is the return on assets for firm $i$ at time $t . \sum_{\kappa=-4}^{4} \mathbb{1}[t=\kappa]$ is a series of year dummies that equal one when the tax reform was $\kappa$ years away, with the dummy variable corresponding to $\kappa=-1$ as the omitted category. $X_{i t}^{\prime}$ is a set of firm- and countrylevel controls (including GDP growth, cost of capital, investment as share of GDP in both subsidiary and HQ countries), $\eta_{t}$ is a year fixed effect, and $\epsilon_{i t}$ is the error term.

The coefficients of interest are the $\delta_{t}$, as they measure the average change in reported profits relative to the $\kappa$ year before or after the reform across the subsidiaries in our sample. Following McCrary (2007), we bin event dummies at endpoints of the event window (in our case, at $t=-4$ and $t=4$ ) such that the end dummies include all reforms occurring 4 or more years beyond the window. This is to account for the different timing of tax rate cuts across countries, which yields an unbalanced panel for event times. ${ }^{24}$

We use the event study sample described in Section 3 focusing on the subsidiaries in countries that had only one tax cut in the event window. It is the simplest iteration of this exercise with the most straightforward interpretation. Restricting our analysis to this subset of countries avoids issues related to possible anticipation of tax changes as well as slow and staggered sequential introductions of large tax rate cuts. ${ }^{25}$ We implement this restriction at the firm level, such that firms that experienced only one tax rate cut in their "sample lifetime" are also included even if the country they are located in had multiple tax changes throughout the entire sample period. ${ }^{26}$

We do not include a control group in our event study analysis sample. There are several reasons for not doing so. First, the ideal control group would include firms located in countries where no tax rate changes occurred during our sample period. Most countries have between 1 to 3 tax rate cuts between 2005 - 2018, with only 7 countries not enacting any changes in this period. This would not constitute a representative group of countries relative to those with tax cuts. Second, our event times span different years across different countries. If we built a synthetic control group for any one particular country, it is not clear how this would apply to other countries with different time lines and reference years. In principle it could be possible to treat each tax rate cut as a separate event and construct a synthetic group for

\footnotetext{
${ }^{24}$ The binning at the end-points of the window is the reason we do not plot the endpoint estimates in the event study graphs.

${ }^{25}$ For example, the UK scheduled an 11 percentage point tax cut to be implemented on a one-percentage point annual reduction from 2010 to 2022.

${ }^{26}$ In our sample, a firm located in a country with tax cuts in 2009 and 2013 (i.e., Sweden), for example, could still be in the sample if the firm only reports data between 2004 and 2011 and not after, or between 2010 and 2017, but not before. We include a map of the countries included in our event study sample in Figure B5b.
} 
each of those weighting the outcomes of each of those event studies. ${ }^{27}$. However, the data requirement of such an approach are too stringent for our context and thus we favor the more straightforward approach of omitting a control group. ${ }^{28}$ We use the variation in tax rate changes and between different management types to identify the effects of tax rate cuts for the firms in our event study sample.

Table III reports the results for the simple pre- and post- analysis, averaging across the relevant time periods. Columns (1,4 and 7) include only country and year fixed effects, Columns (2, 5 and 8) add firm and macro-level controls and Columns (3,6 and 9) add MNE fixed effects. Columns 1-3 include the full sample, while columns 4-6 focus on aggressive firms and columns 7-9 on non-aggressive firms, using the tax haven definition of aggressiveness. The coefficient on the interaction between the formal management indicator and the posttax cut indicator is positive in Columns 1-3 which indicates that firm reported profitability increases after a tax rate cut. The coefficients in Column (2) suggest that, following a tax rate cut, firms with formal practices in place report 2.8 percentage points higher ROA in those jurisdictions in the post-period. This positive response is driven by aggressive firms, while we see no reported profitability response from non-aggressive firms. Looking at the within-MNE correlations in Column (3), the results are the closest we get to understanding reallocation patterns across subsidiaries of the same MNE. While the coefficient value halves, it is still significant in the post-period for firms with formal management ( $\mathrm{p}$ value $=0.052$ ). This is also driven by aggressive firms (Columns 6 and 9).

Figure IV shows the coefficient plots of the time event dummy variables from $t=-3$ to $t=3$, setting $t-1$ as the reference time period (highlighted by the dashed line). Panel (a) plots event dummy coefficients separately for firms with formal and informal management in place. As the sample only includes subsidiaries in country-years that experienced a tax rate cut, the interpretation of each coefficient is the change in reported profits relative to the year prior to the tax cut across the sample. Subsidiaries with formal management are represented by white diamonds, and subsidiaries with informal management are represented by shaded diamonds. There is no evidence of a significant pre-trend in periods before the tax rate cut, but there is a clear positive and statistically significant response starting from

\footnotetext{
${ }^{27}$ As in, for example, Campos et al. (2014); Dube and Zipperer (2015)

${ }^{28}$ Given the staggered nature of the tax rate cuts we analyze, including a control group brings with it a concern that the estimated effects may be contaminated when "already-treated" observations act as control group (Borusyak and Jaravel; Working Paper; Callaway and Sant'Anna; 2020; de Chaisemartin and D'Haultfoeuille; 2020; Sun and Abraham; 2020). These problems arise from negative weights in the computation of the average treatment effect. As such, we instead opt for a conservative sample selection that allows for the clearest interpretation of the differential patterns we are concerned with.
} 
$t=0$ onward for firms with formal management. Firms with informal management show a delayed response, which is not statistically different from zero until period $t=+2$. In Panel (b) we plot that the difference between firms with formal and informal management. Again there is no difference in pre-trends, and the difference is statistically significant in all post time periods.

We conducted a series of robustness and sensitivity checks with various definitions of event windows and event definitions, including accounting for multiple tax changes within the sample period, accounting for the size of the tax change, and limiting the sample to a balanced sample. These results are summarized in Figure B6 in the Appendix and yield qualitatively similar patterns.

\subsection{Explaining reporting patterns: evidence for profit shifting}

Once firms exhaust local options, they will consider whether and how much of their excess profits to move to other jurisdictions under the MNEs global operations. ${ }^{29}$ First, in Panel A of Table IV we repeat the specification from Column (5) in Table II for the sub-samples of firms across two definitions of aggressive avoidance behavior detailed in Section 3. In Columns (1) and (3) we proxy for aggressive and non-aggressive behavior with above- and below-median BTDs, respectively, and in Columns (2) and (4) with the presence or no presence of tax haven in the firm ownership tree. The interaction coefficients suggest that firms with formal management report significantly lower ROAs in higher tax environments, but only if firms are also classified as aggressive tax avoiders. We find no significant relationship for firms that are less likely to be aggressive. Figure $\mathrm{V}$ plots the marginal effects across the distribution of the management score, consistent with the results in Table IV.

In Panel B of Table IV we instead consider the probability a firm reports "near-zero" ROA. The Table reports the results of a linear probability model with an indicator taking a value of 1 if ROA is within 0.05 percentage points of zero as an outcome variable. We proxy for aggressive behavior as in Panel A, and similarly find that the interaction coefficient between formal management and subsidiary corporate tax rate is positive and significant only for firms that are classified as aggressive. These results are clearest in a simple plot of the distribution of ROA for firms with formal and informal management, in high- and lowtax countries. Figure VI shows that a larger share of MNEs operating in high-tax countries

\footnotetext{
${ }^{29}$ In our conceptual framework we do not need to distinguish between the possible modes of profit shifting that firms use, but rather assume that firms will use whatever modes are available and suit them best. A deeper exploration of these modes is outside the scope of this paper.
} 
report near zero ROAs relative to MNEs operating in low-tax countries. No such pattern is apparent in firms with informal management. Again, consistent with profit shifting behavior, we show the bunching patterns are driven by firms classified as "aggressive" (Figure VII). ${ }^{30}$

\subsection{Explaining profit reporting patterns: alternative channels}

Our evidence thus far suggests that better managed firms report lower profitability in hightax countries. While this is consistent with better management enabling profit shifting, these patterns could also be explained by other reasons. In this section, we discuss two potential alternatives - differences in performance and differences in ability to take advantage of investment tax incentives - and show why we believe the data is most consistent with the profit shifting channel. We summarize these results in Table V.

Performance Columns (1) reports the results of our baseline specification with a common measure of productivity, log of sales per employee, as the outcome variable. The interaction term between formal management and corporate tax rate is positive and significant, suggesting that despite having lower profitability, firms with formal management are (if anything) more productive in high-tax countries. ${ }^{31}$ A similar pattern in the dynamic exercise with our event study suggests there is no significant difference in productivity response between formal and informal management firms following a tax rate cut (Figure B2). Thus, "real" performance differences do not seem to explain lower profitability in high tax countries for firms with formal management practices.

Investment In our conceptual framework, we outlined that firms have two primary channels to minimize tax liabilities (local investment tax deductions or profit shifting) and management practices could work through either channel. Firms could use tax law provisions within their jurisdictions to lower their taxable profits at a first instance. Using fixed asset growth as a proxy for investment, Columns (2) reports the results with this alternative outcome variable. We find that firms in higher-tax countries have lower investment rates, but we do not find evidence that this is differentially true for firms that have formal management in place. Another useful variable for insight into this question is the amount that a firm claims as depreciation in a year, though data for this variable is quite limited. In principle, the

\footnotetext{
${ }^{30}$ We use the definition of aggressiveness based on having BTD above median, and we report the Haven definition in the Appendix, Figure B4.

${ }^{31}$ To be sure, there is a clear positive relationship between management and productivity in both low- and high-tax countries, though the level of productivity is higher in high-tax countries (Figure B1).
} 
difference between a firm's reported EBIT (earnings before interest and taxes) and EBITDA (earnings before interest, taxes and depreciation of assets) should give us the depreciation amount claimed. However, in practice these lines are not always reported in income statements and thus we have a large share of missing values. Profit and loss statements, where ROA comes from, are relatively more complete and another reason ROA is a more commonly used metric. Still, we run an exercise of iterating through these various outcomes and report the results in the Appendix (Table B3). ${ }^{32}$ For this selected sample of firms, the interaction coefficient between management and the tax rate suggests depreciation plays only a minor role in explaining the differences we are interested in. As such, we see deductions from investment as part of the story, but not contributing to our understanding of the difference in reported profits between high and low tax jurisdictions.

The role of individual managers Our paper focuses on management practices that are distinct from individual manager quality as there is a large literature on the role of individual managers and accountants on firm's performance (Bertrand and Schoar; 2003; Zwick; 2021) and on firm's tax avoidance (Dyreng et al.; 2010; Koester et al.; 2017). In this literature, the effects of individual managers are separated from that of firm specific characteristics by exploiting the movement of managers across firms. Data constraints prevent us from replicating this approach, ${ }^{33}$ but we run a simple exercise to consider this channel with available measures of level of centralization from the WMS and CEO and CFO compensation data from Orbis.

A measure of the role of HQ managers is the level of centralization of decision-making. In Columns (3) and (4), we use a WMS proxy for centralization described in Section 3 and split the sample into firms that have decisions made primarily jointly or at the plant (decentralized) or primarily at HQ (centralized). The interaction term is only significantly negative for firms that make decisions primarily at the HQ. This is consistent with our conceptual framework, where we argue that decisions about allocation of profits across subsidiaries (and consequently profit shifting) are taken at the parent level but need good management structures at the local level to be effectively executed.

An alternative measure of the quality of $\mathrm{HQ}$ managers used in the literature is the CEO and $\mathrm{CFO}$ compensation. The Orbis directors data includes the latest information on position and salary of various executive managers, but is often missing the time frame in which they

\footnotetext{
${ }^{32}$ We show the sample is selected (Column 3 reports the same specification as in Column 1 using only the firms with EBIT and EBITDA data available), so results should be interpreted with caution.

${ }^{33}$ Our focus is on both private and public firms, and directors data is mostly available for the latter.
} 
serve. As such, we cannot build a panel of executive compensation and aggregate over the executive team, as in Armstrong et al. (2012); Desai and Dharmapala (2006). Instead, we consider the latest current average salary within Chief Executive Officers (CEOs) and Chief Financial Officers (CFOs). ${ }^{34}$ This value does not vary over time, and only $2.8 \%$ of managers hold contemporaneous positions in more than one firm. Column (5) repeats the baseline specification for the sample of firms for which we have executive compensation data to highlight the selectiveness of this sample. The interaction term is still negative and significant, but the magnitude is almost four times larger than the "full sample" baseline coefficient. Still, controlling for CFO compensation (Column 6) or CEO compensation (Column 7) does not meaningfully change the magnitude of the interaction coefficient across specifications. These results suggest that the effect of formal management practices on a firm's capacity to shift profits is relevant beyond the effect of individual manager quality.

Summary on channels Taken together, the patterns of lower profit reporting by better managed firms that we observe in higher tax countries countries appear to be driven by profit shifting activities. As the results in Tables IV and V show, differences in profitability between high- and low- tax countries cannot be attributed to differences in performance, investment or individual managers.

\section{Mechanisms: how management practices enable profit shifting}

As the patterns we find are consistent with better managed firms engaging in profit shifting practices, the next question becomes how plant-level management structures could affect decisions made at the MNE headquarters. In this section, we consider whether our management measure is picking up fundamental (or "real") practices that "enable" or "constrain" profit shifting activities or whether it is likely to be proxying for other unobservable characteristics such as simply overall "competence". We use enabling to mean that firms with higher scores in a particular practice are more likely to report lower profits in high-tax countries relative to low-tax countries. We use constraining to mean that, despite firms looking to minimize reported profits in a high-tax jurisdiction, higher scores in a particular practice are correlated with higher reported profits.

\footnotetext{
${ }^{34}$ The average salary in the finance, accounting and legal departments within our sample of MNEs is similar to the the CFO average salary.
} 


\subsection{Specific practices and reported profitability}

The WMS includes individual measures for 18 different management practices across four broad areas, as discussed in Section 3: lean manufacturing, production monitoring, targetsetting and people management. Each practice carries a wealth of information about the inner workings of the firm. Thus far we have aggregated the 12 operations-related questions into a single index, but there are three distinct "sub-areas" within the operations section. For this exercise, we also use the remaining 6 questions related to people management. We discuss each set in turn.

The results we describe below are summarized in Figure VIII, which plots the coefficients of the interaction term between subsidiary tax rate and each of the each of the 18 management practices from the WMS survey with profitability as outcome variable. ${ }^{35}$ We report the interaction coefficients for aggressive firms (green circles) and non-aggressive firms (orange circles), using the presence of tax haven in MNE ownership tree to define aggressiveness. We include corresponding tables with individual practices and sub-indices in the Appendix: Tables B4 and B5 for profitability and repeat the exercise for productivity in Tables B6 and B7.

Manufacturing competence: lean operations The closest metric we have to "having one's act together" is the first two topics in the WMS questionnaire: the interviewer asks the manager to describe the production process in their firm, and further probes about the adoption of modern manufacturing best practices and the rationale for adoption. A lower score on these topics suggests a firm has relatively rudimentary production processes, with little automation and independent (ad-hoc) introduction of new processes and practices, and the adoption of practices was primarily a necessary response. A higher score implies a firm has effective and optimized production systems (including modern manufacturing processes such as just-in-time production, automation and flexible support systems), and their introduction was borne out of a proactive competitiveness drive. The results suggest that aggressive firms with better lean operations practices report lower profits in higher-tax countries. Nonaggressive firms, however, have a substantial positive relationship. If the patterns we interpret as profit shifting were driven only by "overall manufacturing competence", we would expect to see both aggressive and non-aggressive firms to have a negative correlation.

\footnotetext{
${ }^{35}$ Figure and B3 repeats that exercise for performance.
} 
Tractability and Predictability: monitoring and target-setting practices The next set of practices, aggregated in the monitoring index, measure the quality and rigour of performance tracking at the firm. The five processes measured here include the set of key performance metrics used and recorded at the firm, the frequency of measurement as well as the structure, quality and follow-up of managerial performance meetings. A lower score on these topics suggests a firm has an inadequate number of performance indicators (either too few or too many) tracked with inadequate regularity (or not tracked at all), and little to no structure in managerial performance review meetings. A higher score implies a firm has a reasonable number of performance indicators that reflect their overall performance, tracked with regular oversight and structured review meetings including clear documentation of outcomes and accountability of follow-up plans.

The coefficient on the interaction term in Figure VIII is significantly negative for all the individual practices for aggressive firms. For non-aggressive firms we find no significant relationship on average, and only one of the individual questions is significant (and positive). This is consistent with our conceptual framework that focuses on predictability and tractability of production as important enablers of profit shifting. The practices in this index directly measure a firm's ability to plan production patterns so they predictable and consistent, but also be able to adjust their production levels on short-notice to act on policy directives from HQ.

The set of practices relating to target-setting provide a more nuanced picture. The five practices in this index broadly measure the type, construction and time horizon of targets and goals of the organization (both plant and firm). The first two practices measure linkages between HQ and the plant level targets. More specifically, firms with higher scores in "types of targets" tend to include shareholder concerns in their target-setting, while those with lower scores primarily focus on operational and local financial goals. Firms with higher scores in "interconnection of targets" tend to build targets that iteratively link the work on the shop floor to the overall firm targets. The other three topics, however, are primarily measuring plant-specific practices relating to the time horizon of goals, the difficulty of plant-specific goals and how clear and understandable the goals are to shop-floor workers. Firms with higher scores on these practices have short, medium and long-term horizons, targets that are tough but achievable and shopfloor workers have a good understanding of their targets and those of the plant. Firms with lower scores mostly focus on short-run goals, have targets that are either too easy or too hard, and shopfloor workers are unlikely to understand their goals or those of the plant.

The interaction coefficient on the average target-setting index is not significant for neither 
aggressive nor non-aggressive firms. However, the two practices related to targets that link HQ and subsidiary are significantly negative for aggressive firms. This is consistent with our conceptual framework, as a focus on shareholder value and strong linkages between plant and HQ goals would enable better reallocation of profits across subsidiaries. These latter three measures, however, speak to specific local goals of the manufacturing plant, and thus would not necessarily have a direct relationship with profit reporting decisions coming from the HQ.

Incentives and alignment: people management The last set of practices in the survey relate to people management. The topics cover how firms find and recruit good workers, evaluate performance to reward and promote good employees as well as deal with poor performers, and how firms retain their top talent. While these practices relate primarily to the shopfloor workers, three questions include aspects related to managerial incentives as well (rewarding performance, promotions and distinctive workplace). Firms with higher scores on these three practices would discuss having performance-based rewards and professional development for at least their managers (even if shopfloor are rewarded based on tenure), and creating a "distinctive value proposition" that attracts top talent to their firm instead of competitors. Firms with higher scores on the other three practices would have regular local performance assessments of their shopfloor workers, address underperformance quickly, and go to great lengths to retain their best workers in their plant.

The interaction effect for the overall index is negative for aggressive firms, though only the three practices including aspects related to performance or promotions seem to enable profit shifting. One possibility is that aggressive firms align their incentives to base bonuses on MNE performance instead of local plant performance. Evidence suggests this is likely the case, as we can verify with the WMS measures of bonus allocation. ${ }^{36}$ This is consistent with our conceptual framework in that firms need to have the basic set of monitoring and targetsetting tools as a platform from which to build effective incentives for their managers. While this allows for a link to the complementary literature on managerial fixed effects driving profit shifting, it is outside the scope of this paper and we leave further exploration of this interaction to future work.

\footnotetext{
${ }^{36}$ Panel B of Tables B5 shows that firms offering larger manager bonuses tend to report lower profits in higher tax countries - but only if the bonuses depend on MNE performance and only in case of aggressive firms.
} 


\subsection{Alternatives: general competence or characteristics}

Broadly, our results show that practices linked to tractability and predictability of production (that is, operations), as well as firm-related incentives (and not plant-related incentives) are most likely to enable profit shifting — but only for firms also classified as aggressive tax avoiders. The same specifications using productivity as an alternative outcome yield almost the opposite result, suggesting these firms are significantly more productive in real terms but not in reported profitability terms (Figure B3). However, the management practices that we measure could simply be a proxy for general competence, where a firm that is well-managed also has good earnings management, or a number of other confounding firm characteristics.

In this scenario, our index provides little tangible information to elucidate what profitshifters actually do. If this were the case, we would expect to see a more consistent relationship between the set of individual practices and reported profitability, especially those that measure plant-level competence that is relatively unrelated to $\mathrm{HQ}$ decision-making. It is also unlikely that management is simply proxying for other characteristics. We verify that most relevant characteristics, such as decentralization, firm-level aggressiveness and tax rate of locations, are not systematically correlated with either the formal management indicator or the continuous management index (Table B1). We find that larger firms and those that have at least one subsidiary in a tax haven tend to be better managed, but we include three key measures of firm size (in terms of number of employees, number of subsidiaries and fixed assets) as controls in all our main specifications and use various proxies of firm aggressiveness to mitigate this issue.

\section{Conclusion}

In this paper, we revisit the relationship between management practices and firm performance, focusing on the link with firm profitability. We document that there are substantial and significant differences in reported profitability depending on the statutory tax rates of the subsidiary location for multinational firms. We find the link between better management and higher reported profitability is only present in low-tax jurisdictions, and evidence that this behavior is consistent with better managed firms being more able to engage in profit shifting activities. Practices related to tractable and predictable production, as well as properly aligned incentives are most likely to enable such actions. Using an event study design, we show better managed firms are also more likely to respond to a tax cut with reporting higher profits in the newly-lower tax jurisdiction. We consider possible determinants of this 
pattern, and rule out that this is driven by "real" performance differences. We also do not find evidence of differential take-up of local tax incentives.

The results in this paper are important from a policy perspective. Our results suggest that, while better firm management may increase firm productivity and "real" profitability, they also seem to reduce reported profitability in high-tax countries. Lower reported profits can lead to lower corporate tax revenues, having potentially important welfare implications. Further, this is relevant for countries engaging in government-funded policies to improve management quality of firms. While we are not suggesting that governments should stop funding these projects altogether, an understanding of the multiple potential effects of management beyond productivity should factor into the cost-benefit analysis.

More generally, the results presented in this paper are likely to be lower bound estimates of how large the effect of management is for profit shifting. This is because profits reported by firms are generally different between tax returns and accounting statements, as Bilicka (2019) shows. This difference is markedly larger for multinational firms and thus the evidence shown here may be even more pronounced with tax returns data instead of accounting data for reported MNE profits. Replicating this exercise with tax records data is a fruitful area of future work. 


\section{References}

Abadie, A., Athey, S., Imbens, G. W. and Wooldridge, J. (2017). When should you adjust standard errors for clustering?, Working Paper 24003, National Bureau of Economic Research.

Adams, R., Almeida, H. and Ferreira, D. (2005). Powerful CEOs and their impact on corporate performance, Review of Financial Studies 18(4): 1403-1432.

Aghion, P., Bloom, N., Lucking, B., Sadun, R. and Van Reenen, J. (2021). Turbulence, firm decentralization, and growth in bad times, American Economic Journal: Applied Economics 13(1): 133-69.

Altig, D., Barrero, J. M., Bloom, N., Davis, S. J., Meyer, B. H. and Parker, N. (2020). Surveying business uncertainty, Journal of Econometrics .

Armstrong, C. S., Blouin, J. L., Jagolinzer, A. D. and Larcker, D. F. (2015). Corporate governance, incentives, and tax avoidance, Journal of Accounting and Economics 60(1): 1 $-17$.

Armstrong, C. S., Blouin, J. L. and Larcker, D. F. (2012). The incentives for tax planning, Journal of Accounting and Economics 53(1): 391 - 411.

Bandiera, O., Guiso, L., Prat, A. and Sadun, R. (2015). Matching Firms, Managers, and Incentives, Journal of Labor Economics 33(3): 623-681.

Ben-David, I., Graham, J. R. and Harvey, C. R. (2013). Managerial Miscalibration, The Quarterly Journal of Economics 128(4): 1547-1584.

Bender, S., Bloom, N., Card, D., Van Reenen, J. and Wolter, S. (2018). Management practices, workforce selection, and productivity, Journal of Labor Economics 36(S1).

Bertrand, M. and Schoar, A. (2003). Managing with Style: The Effect of Managers on Firm Policies*, The Quarterly Journal of Economics 118(4): 1169-1208.

Bilicka, K. A. (2019). Comparing uk tax returns of foreign multinationals to matched domestic firms, American Economic Review 109(8): 2921-53.

Bloom, N., Brynjolfsson, E., Foster, L., Jarmin, R., Patnaik, M., Saporta-Eksten, I. and Van Reenen, J. (2019). What drives differences in management practices?, American Economic Review 109(5): 1648-83. 
Bloom, N., Bunn, P., Chen, S., Mizen, P., Smietanka, P. and Thwaites, G. (2019). The Impact of Brexit on UK Firms, NBER Working Papers 26218, National Bureau of Economic Research, Inc.

Bloom, N., Eifert, B., Mahajan, A., McKenzie, D. and Roberts, J. (2013). Does Management Matter? Evidence from India, The Quarterly Journal of Economics 128: 1-51.

Bloom, N., Genakos, C., Sadun, R. and Van Reenen, J. (2012). Management practices across firms and countries, The Academy of Management Perspectives 26: 12-33.

Bloom, N., Lemos, R., Sadun, R., Scur, D. and Van Reenen, J. (2014). The New Empirical Economics of Management, Journal of the European Economic Association 12(4).

Bloom, N., Lemos, R., Sadun, R. and Van Reenen, J. (2020). Healthy business? managerial education and management in health care, The Review of Economics and Statistics 102(3): 506-517.

Bloom, N., Ohlmacher, S. and Tello-Trillo, C. (2020). Management and inequality. Stanford Mimeo.

Bloom, N., Sadun, R. and Van Reenen, J. (2012). The organization of firms across countries, The Quarterly Journal of Economics 127(4): 1663-1705.

Bloom, N., Sadun, R. and Van Reenen, J. (2016). Management as a technology?, Working Paper 22327, National Bureau of Economic Research.

Bloom, N. and Van Reenen, J. (2007). Measuring and explaining management practices across firms and countries, The Quarterly Journal of Economics 122: 1351-1408.

Borusyak, K. and Jaravel, X. (Working Paper). Revisiting event study designs.

Callaway, B. and Sant'Anna, P. H. (2020). Difference-in-differences with multiple time periods, Journal of Econometrics .

Campos, N. F., Coricelli, F. and Moretti, L. (2014). Economic Growth and Political Integration: Estimating the Benefits from Membership in the European Union Using the Synthetic Counterfactuals Method, IZA Discussion Papers 8162, Institute of Labor Economics (IZA).

Cornwell, C., Schmutte, I. and Scur, D. (2021). Building a productive workforce: the role of structured management practices, Management Science forthcoming. 
Cristea, A. D. and Nguyen, D. X. (2016). Transfer Pricing by Multinational Firms: New Evidence from Foreign Firm Ownerships, American Economic Journal: Economic Policy 8(3): 170-202.

Davies, R. B., Martin, J., Parenti, M. and Toubal, F. (2018). Knocking on tax haven's door: Multinational firms and transfer pricing, The Review of Economics and Statistics 100(1): 120-134.

de Chaisemartin, C. and D'Haultfoeuille, X. (2020). Difference-in-Differences Estimators of Intertemporal Treatment Effects, Papers 2007.04267, arXiv.org.

Desai, M. A. (2003). The divergence between book income and tax income, Tax Policy and the Economy 17: 169-206.

Desai, M. A. and Dharmapala, D. (2006). Corporate tax avoidance and high-powered incentives, Journal of Financial Economics 79(1): 145 - 179.

Desai, M. A. and Dharmapala, D. (2009). Corporate Tax Avoidance and Firm Value, The Review of Economics and Statistics 91(3): 537-546.

Desai, M. A., Foley, C. F. and Hines, J. J. (2006). The demand for tax haven operations, Journal of Public Economics 90(3): 513-531.

Desai, M. A., Foley, C. F. and Hines, J. R. (2004). A Multinational Perspective on Capital Structure Choice and Internal Capital Markets, Journal of Finance 59(6): 2451-2487.

Dessein, W. and Prat, A. (2019). Organizational Capital, Corporate Leadership, and Firm Dynamics, CEPR Discussion Papers 13513, C.E.P.R. Discussion Papers.

Dischinger, M. and Riedel, N. (2011). Corporate taxes and the location of intangible assets within multinational firms, Journal of Public Economics 95(7): 691 - 707.

Dowd, T., Landefeld, P. and Moore, A. (2017). Profit shifting of U.S. multinationals, Journal of Public Economics 148: 1 - 13.

Dube, A. and Zipperer, B. (2015). Pooling multiple case studies using synthetic controls: An application to minimum wage policies, IZA Discussion Papers 8944, Bonn.

Dyreng, S. D., Hanlon, M. and Maydew, E. L. (2010). The effects of executives on corporate tax avoidance, The Accounting Review 85(4): 1163-1189. 
Erickson, M., Hanlon, M. and Maydew, E. L. (2004). How Much Will Firms Pay for Earnings that do not Exist? Evidence of Taxes Paid on Allegedly Fraudulent Earnings, The Accounting Review 79(2): 387-408.

Fuest, C., Peichl, A. and Siegloch, S. (2018). Do Higher Corporate Taxes Reduce Wages? Micro Evidence from Germany, American Economic Review 108(2): 393-418.

Gibbons, R. and Henderson, R. (2012). What do managers do?, in R. Gibbons and J. Roberts (eds), The Handbook of Organizational Economics, Princeton University Press.

Giorcelli, M. (2019). The long-term effects of management and technology transfers, American Economic Review 109(1): 121-52.

Gumpert, A., Hines, J. R. and Schnitzer, M. (2016). Multinational firms and tax havens, The Review of Economics and Statistics 98(4): 713-727.

Hines, J. R. and Rice, E. M. (1994). Fiscal Paradise: Foreign Tax Havens and American Business, The Quarterly Journal of Economics 109(1): 149-182.

Huizinga, H., Laeven, L. and Nicodeme, G. (2008). Capital structure and international debt shifting, Journal of Financial Economics 88(1): 80-118.

Ichniowski, C., Shaw, K. and Prennushi, G. (1997). The effects of human resource management practices on productivity: A study of steel finishing lines, American Economic Review 87: 291-313.

Johannesen, N., Tørsløv, T. and Wier, L. (2020). Are less developed countries more exposed to multinational tax avoidance? method and evidence from micro-data, World Bank Economic Review 34(3): 790-809.

Knack, S., Parks, B. C., Harutyunyan, A. and DiLorenzo, M. (2020). How Does the World Bank Influence the Development Policy Priorities of Low-Income and Lower-Middle Income Countries?, Policy Research Working Paper Series 9225, The World Bank.

Koester, A., Shevlin, T. and Wangerin, D. (2017). The role of managerial ability in corporate tax avoidance, Management Science 63(10): 3285-3310.

Lemos, R., Muralidharan, K. and Scur, D. (2021). Personnel management and school productivity: Evidence from india, Working Paper 28336, National Bureau of Economic Research. 
Manzon, Jr., G. B. and Plesko, G. A. (2002). The Relation between Financial and Tax Reporting Measures of Income., Tax Law Review 55(2).

McCrary, J. (2007). The effect of court-ordered hiring quotas on the composition and quality of police, American Economic Review 97(1): 318-353.

Scur, D., Sadun, R., Van Reenen, J., Lemos, R. and Bloom, N. (2021). The World Management Survey at 18: lessons and the way forward, Oxford Review of Economic Policy 37(2): $231-258$.

Serrato, J. C. S. and Zidar, O. (2016). Who Benefits from State Corporate Tax Cuts? A Local Labor Markets Approach with Heterogeneous Firms, American Economic Review 106(9): 2582-2624.

Sun, L. and Abraham, S. (2020). Estimating dynamic treatment effects in event studies with heterogeneous treatment effects, Journal of Econometrics .

Torslov, T. R., Wier, L. S. and Zucman, G. (2018). The missing profits of nations, Working Paper 24701, National Bureau of Economic Research.

Walker, F. A. (1887). The Source of Business Profits, The Quarterly Journal of Economics $\mathbf{1}(3): 265-288$.

Wier, L. and Reynolds, H. (2018). Big and 'unprofitable', Working paper, UNU-WIDER.

Zwick, E. (2021). The costs of corporate tax complexity, American Economic Journal: Economic Policy 13(2): 467-500. 


\section{Tables and figures}

Table I: Descriptive Statistics for Each Sample.

\begin{tabular}{|c|c|c|c|c|c|c|c|c|}
\hline & \multicolumn{4}{|c|}{ Low tax vs High tax } & \multicolumn{4}{|c|}{ Aggressive vs Non-Aggressive } \\
\hline & $\begin{array}{c}\text { Low tax } \\
\text { Mean }\end{array}$ & $\begin{array}{l}\text { High tax } \\
\text { Mean }\end{array}$ & $\begin{array}{c}\text { Low tax } \\
\mathrm{N}\end{array}$ & $\begin{array}{c}\text { High tax } \\
\mathrm{N}\end{array}$ & $\begin{array}{c}\text { Non-Agg } \\
\text { Mean }\end{array}$ & $\begin{array}{l}\text { Agg } \\
\text { Mean }\end{array}$ & $\begin{array}{c}\text { Non-Agg } \\
\text { N }\end{array}$ & $\begin{array}{c}\text { Agg } \\
\text { N }\end{array}$ \\
\hline \multicolumn{9}{|c|}{ Panel A: Management-only sample } \\
\hline Employment & 1445.03 & 921.59 & 10771 & 5305 & 1124.32 & 1563.32 & 8477 & 6741 \\
\hline Profit \& Loss before tax & 16707.74 & 19471.80 & 10771 & 5305 & 8267.07 & 31069.29 & 8477 & 6741 \\
\hline Return on Assets & 0.06 & 0.05 & 10771 & 5305 & 0.02 & 0.12 & 8477 & 6741 \\
\hline Effective Tax Rate & 0.17 & 0.22 & 10017 & 5199 & 0.25 & 0.11 & 8475 & 6741 \\
\hline Management & 3.32 & 3.41 & 10771 & 5305 & 3.34 & 3.38 & 8477 & 6741 \\
\hline Formal mgmt $=1$ & 0.74 & 0.79 & 10771 & 5305 & 0.75 & 0.77 & 8477 & 6741 \\
\hline \multicolumn{9}{|c|}{ Panel B: Event study sample } \\
\hline Employment & 713.47 & 943.15 & 49225 & 79625 & 644.38 & 1152.57 & 63765 & 53141 \\
\hline Profit \& Loss before tax & 19043.44 & 21687.37 & 49227 & 79629 & 2954.02 & 41999.02 & 63767 & 53143 \\
\hline Return on Assets & 0.05 & 0.01 & 49227 & 79629 & -0.04 & 0.13 & 63767 & 53143 \\
\hline Effective Tax Rate & 0.16 & 0.15 & 41874 & 73991 & 0.18 & 0.12 & 62751 & 53114 \\
\hline Management (avg) & 3.47 & 3.42 & 49227 & 79629 & 3.44 & 3.44 & 63767 & 53143 \\
\hline Formal mgmt $(\operatorname{avg})=1$ & 0.84 & 0.84 & 49227 & 79629 & 0.84 & 0.85 & 63767 & 53143 \\
\hline
\end{tabular}

Note: Data from the World Management Survey (2004-2014) matched with Orbis (2004 to 2018). The Effective Tax Rate is the ratio of reported tax payments to profit and loss before taxes. Management is the average for the WMS operations management questions (including lean management, monitoring and target-setting). Panel A shows descriptive statistics for the sample for which we observe management measures at the firm level. Panel B show descriptive statistics for the firms in our Event Study; that is, firms that are located in countries that experienced one tax rate cut throughout the sample period. Low tax subsidiaries are firms located in countries with below median statutory corporate tax rate in a given year. High tax subsidiaries are firms located in countries with above median statutory corporate tax rate in a given year. Non-aggressive are firms with book tax difference (BTD) below median in a given year and Aggressive are firms with BTD above median in a given year. 
Table II: Summary of Baseline Results With ROA as the Outcome Variable.

\begin{tabular}{|c|c|c|c|c|c|c|}
\hline & $\begin{array}{c}(1) \\
\mathrm{ROA}\end{array}$ & $\begin{array}{c}(2) \\
\mathrm{ROA}\end{array}$ & $\begin{array}{c}(3) \\
\mathrm{ROA}\end{array}$ & $\begin{array}{c}(4) \\
\mathrm{ROA}\end{array}$ & $\begin{array}{c}(5) \\
\mathrm{ROA}\end{array}$ & $\begin{array}{c}(6) \\
\mathrm{ROA}\end{array}$ \\
\hline Formal management $=1$ & $\begin{array}{c}0.007^{* * *} \\
(0.002)\end{array}$ & $\begin{array}{c}0.007 * * * \\
(0.002)\end{array}$ & $\begin{array}{c}0.029^{* * *} \\
(0.007)\end{array}$ & $\begin{array}{c}0.017^{* *} \\
(0.008)\end{array}$ & $\begin{array}{c}0.041^{* * *} \\
(0.015)\end{array}$ & $\begin{array}{c}0.037 \\
(0.030)\end{array}$ \\
\hline Subsidiary corp tax rate & $\begin{array}{c}-0.105^{* * *} \\
(0.036)\end{array}$ & $\begin{array}{c}-0.093^{* *} \\
(0.036)\end{array}$ & $\begin{array}{l}-0.060 \\
(0.038)\end{array}$ & $\begin{array}{c}0.128^{* * *} \\
(0.040)\end{array}$ & $\begin{array}{c}-0.236^{* * *} \\
(0.075)\end{array}$ & $\begin{array}{c}-0.323^{* * *} \\
(0.117)\end{array}$ \\
\hline $\mathrm{MNE}=1$ & $\begin{array}{c}0.015^{* * *} \\
(0.003)\end{array}$ & $\begin{array}{c}0.021^{* * *} \\
(0.008)\end{array}$ & $\begin{array}{c}0.015^{* * *} \\
(0.003)\end{array}$ & & & \\
\hline $\begin{aligned} \mathrm{MNE} & =1 \\
& \times \text { Subsidiary corp tax rate }\end{aligned}$ & & $\begin{array}{l}-0.025 \\
(0.027)\end{array}$ & & & & \\
\hline $\begin{array}{l}\text { Formal management }=1 \\
\quad \times \text { Subsidiary corp tax rate }\end{array}$ & & & $\begin{array}{c}-0.078^{* * *} \\
(0.025)\end{array}$ & $\begin{array}{l}-0.038 \\
(0.028)\end{array}$ & $\begin{array}{c}-0.121^{* *} \\
(0.054)\end{array}$ & $\begin{array}{l}-0.169^{*} \\
(0.098)\end{array}$ \\
\hline Firm controls & $\checkmark$ & $\checkmark$ & $\checkmark$ & $\checkmark$ & $\checkmark$ & $\checkmark$ \\
\hline Country FE & $\checkmark$ & $\checkmark$ & $\checkmark$ & $\sqrt{ }$ & $\sqrt{ }$ & $\checkmark$ \\
\hline Year FE & $\checkmark$ & $\checkmark$ & $\checkmark$ & $\checkmark$ & $\checkmark$ & $\checkmark$ \\
\hline MNE FE & & & & & & $\checkmark$ \\
\hline Observations & 32522 & 32522 & 32522 & 16446 & 16076 & 6084 \\
\hline \# firms & 4241 & 4241 & 4241 & 2458 & 1783 & 617 \\
\hline Dependent Variable Mean & 0.045 & 0.045 & 0.045 & 0.031 & 0.058 & 0.061 \\
\hline Sample & $\begin{array}{l}\text { Baseline } \\
\text { All }\end{array}$ & $\begin{array}{l}\text { Baseline } \\
\text { All }\end{array}$ & $\begin{array}{l}\text { Baseline } \\
\text { All }\end{array}$ & $\begin{array}{l}\text { Baseline } \\
\text { Domestic }\end{array}$ & $\begin{array}{l}\text { Baseline } \\
\text { MNE }\end{array}$ & $\begin{array}{c}\text { Baseline } \\
\text { within GUO }\end{array}$ \\
\hline
\end{tabular}

Note: Data from Orbis and the World Management Survey. Baseline sample includes only firms for which we observe management scores and were directly matched to Orbis financial data. Formal management $=1$ is a dummy equal to one when the average for the WMS operations management questions (including lean management, monitoring and target-setting) is 3 or above, on a scale of 1 to 5 . Subsidiary corp tax rate is the annual statutory corporate tax rate in the country where a firm is operating. The outcome variable in all columns is Returns on Assets (ROA) which is the ratio of profit and loss before taxes and total assets. All specifications include country and year fixed effects. Columns (1) - (4) include only multinationals (MNEs) and Column (5) includes only domestic firms. Year of accounts for MNEs include 2004-2018, and domestic firms year of accounts include 2010-2018. Firm controls for Columns (1) - (4) include log of employment, log of fixed assets and $\log$ of number of subsidiaries in the MNE. Firm controls for Column (5) include log of employment and log number of domestic production sites. Standard errors are robust in columns 1-3 and 5 and clustered at the MNE level in column 4. 
Table III: Pre-post Summary Table, Event Study Sample.

\begin{tabular}{|c|c|c|c|c|c|c|c|c|c|}
\hline \multirow[b]{2}{*}{ Dependent variable: ROA } & \multicolumn{3}{|c|}{ All firms } & \multicolumn{3}{|c|}{ Aggressive firms } & \multicolumn{3}{|c|}{ Non-Aggressive firms } \\
\hline & $(1)$ & $(2)$ & $(3)$ & $(4)$ & $(5)$ & (6) & $(7)$ & (8) & $(9)$ \\
\hline Formal management $=1$ & $\begin{array}{c}-0.023^{* *} \\
(0.010)\end{array}$ & $\begin{array}{c}-0.022^{* * *} \\
(0.008)\end{array}$ & & $\begin{array}{r}-0.024^{* *} \\
(0.011)\end{array}$ & $\begin{array}{c}-0.024^{* * *} \\
(0.008)\end{array}$ & & $\begin{array}{l}-0.003 \\
(0.012)\end{array}$ & $\begin{array}{l}-0.006 \\
(0.013)\end{array}$ & \\
\hline POST tax cut $=1$ & $\begin{array}{l}-0.008 \\
(0.011)\end{array}$ & $\begin{array}{l}-0.010 \\
(0.010)\end{array}$ & $\begin{array}{c}0.002 \\
(0.007)\end{array}$ & $\begin{array}{l}-0.011 \\
(0.011)\end{array}$ & $\begin{array}{l}-0.011 \\
(0.010)\end{array}$ & $\begin{array}{c}0.003 \\
(0.008)\end{array}$ & $\begin{array}{c}0.001 \\
(0.018)\end{array}$ & $\begin{array}{l}-0.007 \\
(0.020)\end{array}$ & $\begin{array}{l}-0.024 \\
(0.018)\end{array}$ \\
\hline $\begin{array}{l}\text { Formal management }=1 \\
\times \text { POST tax } \text { cut }=1\end{array}$ & $\begin{array}{c}0.023^{* *} \\
(0.011)\end{array}$ & $\begin{array}{c}0.028^{* * *} \\
(0.011)\end{array}$ & $\begin{array}{l}0.014^{*} \\
(0.007)\end{array}$ & $\begin{array}{c}0.026^{* *} \\
(0.012)\end{array}$ & $\begin{array}{c}0.030 * * * \\
(0.011)\end{array}$ & $\begin{array}{l}0.013^{*} \\
(0.008)\end{array}$ & $\begin{array}{l}-0.000 \\
(0.022)\end{array}$ & $\begin{array}{c}0.011 \\
(0.022)\end{array}$ & $\begin{array}{c}0.020 \\
(0.016)\end{array}$ \\
\hline Year FE & $\checkmark$ & $\checkmark$ & $\checkmark$ & $\checkmark$ & $\checkmark$ & $\checkmark$ & $\checkmark$ & $\checkmark$ & $\checkmark$ \\
\hline Country FE & $\checkmark$ & $\checkmark$ & $\checkmark$ & $\checkmark$ & $\checkmark$ & $\checkmark$ & $\checkmark$ & $\checkmark$ & $\checkmark$ \\
\hline Macro controls & & $\checkmark$ & $\checkmark$ & & $\checkmark$ & $\checkmark$ & & $\checkmark$ & $\checkmark$ \\
\hline Firm controls & & $\checkmark$ & $\checkmark$ & & $\checkmark$ & $\checkmark$ & & $\checkmark$ & $\checkmark$ \\
\hline MNE FE & & & $\checkmark$ & & & $\checkmark$ & & & $\checkmark$ \\
\hline Observations & 115721 & 100539 & 100539 & 110767 & 96476 & 96476 & 4954 & 4063 & 4063 \\
\hline \# firms & 17581 & 17581 & 17581 & 16861 & 16861 & 16861 & 720 & 720 & 720 \\
\hline Dependent Variable Mean & 0.030 & 0.030 & 0.030 & 0.030 & 0.030 & 0.030 & 0.051 & 0.051 & 0.051 \\
\hline
\end{tabular}

Note: Data from Orbis and the World Management Survey. This table includes only the firms in the Event Study sample, which includes all subsidiaries belonging to an MNE that has at least one plant observed in the WMS. Management data is then averaged across all subsidiaries within an MNE. Aggressive firms are defined as having a subsidiary in a tax haven. Non-aggressive firms are defined as not having any subsidiaries in a tax haven. The event considered here is firms that experienced one tax rate cut during the sample period. POST is a dummy equal to 1 in the years after the tax rate cut. The outcome variable in all columns is ROA (returns on assets) which is the ratio of profit and loss before taxes and total assets. Firm controls include log of employment, log of fixed assets and log of number of subsidiaries in the MNE. Standard errors are clustered at the MNE level in Columns 3, 6 and 9 and robust otherwise. 
Table IV: Primary Channel: Profit Shifting.

\begin{tabular}{|c|c|c|c|c|}
\hline \multirow{2}{*}{$\begin{array}{l}\text { Panel A: Profitability } \\
\text { Dep variable: ROA }\end{array}$} & \multicolumn{2}{|c|}{ Aggressive } & \multicolumn{2}{|c|}{ Non-Aggressive } \\
\hline & (1) & $(2)$ & (3) & (4) \\
\hline Formal management $=1$ & $\begin{array}{c}0.066^{* * *} \\
(0.017)\end{array}$ & $\begin{array}{c}0.061^{* * *} \\
(0.016)\end{array}$ & $\begin{array}{c}0.010 \\
(0.021)\end{array}$ & $\begin{array}{l}-0.020 \\
(0.036)\end{array}$ \\
\hline Subsidiary corp tax rate & $\begin{array}{l}-0.088 \\
(0.087)\end{array}$ & $\begin{array}{c}-0.215^{* *} \\
(0.084)\end{array}$ & $\begin{array}{c}-0.373^{* * *} \\
(0.103)\end{array}$ & $\begin{array}{l}-0.131 \\
(0.155)\end{array}$ \\
\hline $\begin{array}{l}\text { Formal management }=1 \\
\quad \times \text { Subsidiary corp tax rate }\end{array}$ & $\begin{array}{c}-0.220^{* * *} \\
(0.058)\end{array}$ & $\begin{array}{c}-0.256^{* * *} \\
(0.058)\end{array}$ & $\begin{array}{l}-0.000 \\
(0.077)\end{array}$ & $\begin{array}{c}0.184 \\
(0.126)\end{array}$ \\
\hline Observations & 6741 & 11771 & 8477 & 4305 \\
\hline \# firms & 1513 & 1263 & 1590 & 520 \\
\hline Dependent Variable Mean & 0.122 & 0.063 & 0.017 & 0.044 \\
\hline $\begin{array}{l}\text { Panel B: Bunching } \\
\text { Dep variable: Near-zero ROA }=1\end{array}$ & (1) & (2) & (3) & (4) \\
\hline Formal management $=1$ & $\begin{array}{c}-0.149^{* * *} \\
(0.053)\end{array}$ & $\begin{array}{c}-0.118^{* * *} \\
(0.043)\end{array}$ & $\begin{array}{l}-0.057 \\
(0.057)\end{array}$ & $\begin{array}{l}-0.038 \\
(0.089)\end{array}$ \\
\hline Subsidiary corp tax rate & $\begin{array}{l}-0.245 \\
(0.301)\end{array}$ & $\begin{array}{l}-0.013 \\
(0.247)\end{array}$ & $\begin{array}{c}0.351 \\
(0.302)\end{array}$ & $\begin{array}{c}0.552 \\
(0.435)\end{array}$ \\
\hline $\begin{array}{l}\text { Formal management }=1 \\
\quad \times \text { Subsidiary corp tax rate }\end{array}$ & $\begin{array}{c}0.503^{* * *} \\
(0.190)\end{array}$ & $\begin{array}{c}0.496^{* * *} \\
(0.161)\end{array}$ & $\begin{array}{c}0.185 \\
(0.209)\end{array}$ & $\begin{array}{l}-0.084 \\
(0.322)\end{array}$ \\
\hline $\begin{array}{l}\text { Observations } \\
\text { \# firms } \\
\text { Dependent Variable Mean }\end{array}$ & $\begin{array}{l}6741 \\
1513 \\
0.268\end{array}$ & $\begin{array}{l}11771 \\
1263 \\
0.346\end{array}$ & $\begin{array}{l}8477 \\
1590 \\
0.421\end{array}$ & $\begin{array}{c}4305 \\
520 \\
0.392\end{array}$ \\
\hline $\begin{array}{l}\text { Aggressiveness measure } \\
\text { Firm controls } \\
\text { Country FE } \\
\text { Year FE }\end{array}$ & $\begin{array}{c}\text { BTD }>\text { median } \\
\checkmark \\
\checkmark \\
\checkmark\end{array}$ & $\begin{array}{c}\text { Haven } \\
\checkmark \\
\checkmark \\
\checkmark\end{array}$ & $\begin{array}{c}\text { BTD }<\text { median } \\
\boldsymbol{J} \\
\checkmark \\
\checkmark\end{array}$ & $\begin{array}{c}\text { No Haven } \\
\checkmark \\
\checkmark \\
\checkmark\end{array}$ \\
\hline $\begin{array}{l}\text { Note: Data from Orbis and the World Me } \\
\text { (ROA), the ratio of profit and loss bef } \\
\text { variable = } 1 \text { when the ROA is "near zer } \\
\text { value of } 1 \text { when the average for the WM } \\
\text { monitoring and target-setting) is } 3 \text { or a } \\
\text { statutory corporate tax rate in the cou } \\
\text { the sample into "aggressive" (Columns } \\
\text { defined by two different measures: fir } \\
\text { (respectively) and having a subsidiary } \mathrm{i} \\
\text { fixed effects. Firm controls include log o } \\
\text { in the MNE. }\end{array}$ & $\begin{array}{l}\text { gement Survey. } \\
\text { taxes to total a } \\
(0 \pm 0.05) \text {. Forma } \\
\text { perations manag } \\
\text { ve, on a scale of } \\
\text { y where a subsi } \\
\text { ind } 2) \text { and " } \\
\text { having book ta } \\
\text { tax haven or no } \\
\text { mplovment. log }\end{array}$ & $\begin{array}{l}\text { nel A outc } \\
\text { ts. Panel } \\
\text { nanagemer } \\
\text { hent questi } \\
\text { o 5. Subsi } \\
\text { hry is oper } \\
\text { gressive" ( } \\
\text { differences } \\
\text { All specifi } \\
\text { yed assets }\end{array}$ & $\begin{array}{l}\text { variable is Ret } \\
\text { utcome variable } \\
1 \text { is an indicato } \\
\text { (including lean } \\
\text { y corp tax rate } \\
\text { g. Panels A an } \\
\text { umns } 3 \text { and } 4 \text { ) } \\
\text { TD) above or b } \\
\text { ons include cour }\end{array}$ & $\begin{array}{l}\text { n on Assets } \\
\text { s a dummy } \\
\text { that takes a } \\
\text { anagement, } \\
\text { the annual } \\
\text { B separate } \\
\text { ssifications, } \\
\text { ow median } \\
\text { ry and year }\end{array}$ \\
\hline
\end{tabular}


Table V: Alternative Channels: Productivity, Investment, Individual Managers.

\begin{tabular}{|c|c|c|c|c|c|c|c|}
\hline & $\begin{array}{c}(1) \\
\operatorname{Ln}(\text { sales } \\
\text { per emp) }\end{array}$ & $\begin{array}{l}\text { (2) } \\
\text { Fixed Asset } \\
\text { Growth }\end{array}$ & $\begin{array}{c}(3) \\
\mathrm{ROA}\end{array}$ & $\mathrm{ROA}$ & $\mathrm{ROA}$ & $\mathrm{ROA}$ & $\begin{array}{c}(7) \\
\mathrm{ROA}\end{array}$ \\
\hline Formal management $=1$ & $\begin{array}{l}-0.140 \\
(0.109)\end{array}$ & $\begin{array}{c}0.014 \\
(0.013)\end{array}$ & $\begin{array}{c}0.018 \\
(0.021)\end{array}$ & $\begin{array}{c}0.057^{* * *} \\
(0.021)\end{array}$ & $\begin{array}{c}0.115^{* * *} \\
(0.043)\end{array}$ & $\begin{array}{c}0.117^{* * *} \\
(0.043)\end{array}$ & $\begin{array}{c}0.114^{* * *} \\
(0.043)\end{array}$ \\
\hline Subsidiary corp tax rate & $\begin{array}{c}-1.058^{* *} \\
(0.493)\end{array}$ & $\begin{array}{c}-0.184^{* *} \\
(0.076)\end{array}$ & $\begin{array}{c}-0.254^{* *} \\
(0.113)\end{array}$ & $\begin{array}{c}-0.217^{* *} \\
(0.100)\end{array}$ & $\begin{array}{l}-0.171 \\
(0.179)\end{array}$ & $\begin{array}{l}-0.168 \\
(0.178)\end{array}$ & $\begin{array}{l}-0.168 \\
(0.178)\end{array}$ \\
\hline $\begin{array}{l}\text { Formal management }=1 \\
\quad \times \text { Subsidiary corp tax rate } \\
\operatorname{Ln}(\text { CFO compensation })\end{array}$ & $\begin{array}{c}0.980 * * \\
(0.382)\end{array}$ & $\begin{array}{l}-0.068 \\
(0.047)\end{array}$ & $\begin{array}{l}-0.030 \\
(0.081)\end{array}$ & $\begin{array}{c}-0.181^{* *} \\
(0.074)\end{array}$ & $\begin{array}{c}-0.448^{* * *} \\
(0.143)\end{array}$ & $\begin{array}{c}-0.456^{* * *} \\
(0.143) \\
-0.014^{* * *} \\
(0.005)\end{array}$ & $\begin{array}{c}-0.449^{* * *} \\
(0.143)\end{array}$ \\
\hline $\operatorname{Ln}(\mathrm{CEO}$ compensation $)$ & & & & & & & $\begin{array}{c}0.010 \\
(0.007)\end{array}$ \\
\hline Country FE & $\checkmark$ & $\checkmark$ & $\checkmark$ & $\checkmark$ & $\checkmark$ & $\checkmark$ & $\checkmark$ \\
\hline Year FE & $\checkmark$ & $\checkmark$ & $\checkmark$ & $\checkmark$ & $\checkmark$ & $\checkmark$ & $\checkmark$ \\
\hline Firm controls & $\checkmark$ & $\checkmark$ & $\checkmark$ & $\checkmark$ & $\checkmark$ & $\checkmark$ & $\checkmark$ \\
\hline $\begin{array}{l}\text { Observations } \\
\text { \# firms } \\
\text { Dependent Variable Mean } \\
\text { Sample }\end{array}$ & $\begin{array}{c}15620 \\
1759 \\
12.370 \\
\text { Baseline } \\
\text { All }\end{array}$ & $\begin{array}{c}12964 \\
1721 \\
0.076 \\
\text { Baseline } \\
\text { All }\end{array}$ & $\begin{array}{c}6862 \\
764 \\
0.060 \\
\text { Baseline } \\
\text { Decentr. }\end{array}$ & $\begin{array}{c}9214 \\
1019 \\
0.056 \\
\text { Baseline } \\
\text { Centr. }\end{array}$ & $\begin{array}{c}3434 \\
321 \\
0.067 \\
\text { Executive } \\
\text { Comp. }\end{array}$ & $\begin{array}{c}3434 \\
321 \\
0.067 \\
\text { Executive } \\
\text { Comp. }\end{array}$ & $\begin{array}{c}3434 \\
321 \\
0.067 \\
\text { Executive } \\
\text { Comp. }\end{array}$ \\
\hline
\end{tabular}

Note: Data from Orbis and the World Management Survey. Samples: Baseline sample includes only firms for which we observe management scores and were directly matched to Orbis financial data. Baseline decentralized and centralized samples include only firms that scored above 3 and below 3 (respectively) on the WMS centralization measure, which is a score from 1 (most centralized, all decisions made at HQ) to 5 (most decentralized, all decisions made at the plant level). The index is based on two questions that measure the level of decentralization of decision making in terms of new product introductions and sales and marketing. Executive Comp sample includes only firms in the baseline sample for which we also have executive compensation data from Orbis. Variables: Formal management $=1$ is a dummy equal to one when the average for the WMS operations management questions (including lean management, monitoring and target-setting) is 3 or above, on a scale of 1 to 5 . Subsidiary corp tax rate is the annual statutory corporate tax rate in the country where a firm is operating. $\ln (\mathrm{CFO}$ compensation) is the natural logarithm of chief finance officer compensation, $\ln (\mathrm{CEO}$ compensation) is the natural logarithm of chief executive officer compensation. The dependant variable in Column (1) is log of sales per employee, in Column (2) growth rate of fixed assets and in Columns (3) - (7) it is ROA (returns on assets), which is the ratio of profit and loss before taxes and total assets. Controls: Firm controls include log of employment, $\log$ of fixed assets and log of number of subsidiaries in the MNE. All specifications include country and year fixed effects. Standard errors are robust in all columns. 
Figure I: Average Management Score of Multinationals and Dispersion Within Countries.

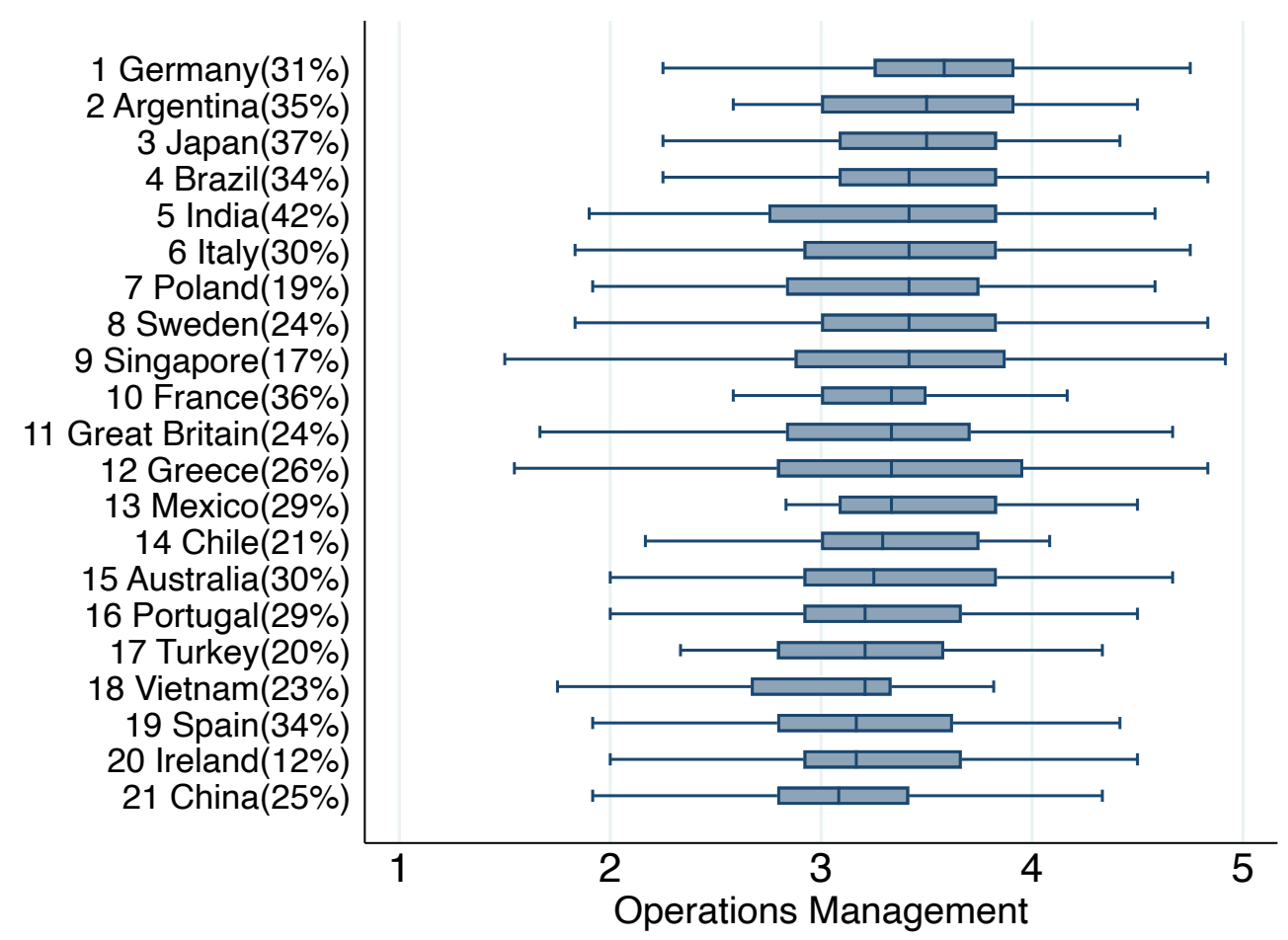

Note: Data from the World Management Survey and Center for Business Taxation Tax Database. The average statutory corporate tax rates across 2004 - 2019 is noted in brackets next to country names. Firm-level management is the average for the WMS operations management questions (including lean management, monitoring and target-setting). This graph only includes data from 1,783 subsidiaries belonging to the multinationals in the baseline sample. Each row shows the median and the interquartile range of the management score for all firms in each country. 


\section{Figure II: ROA and Operations Management in Low- and High-tax Country-years.}
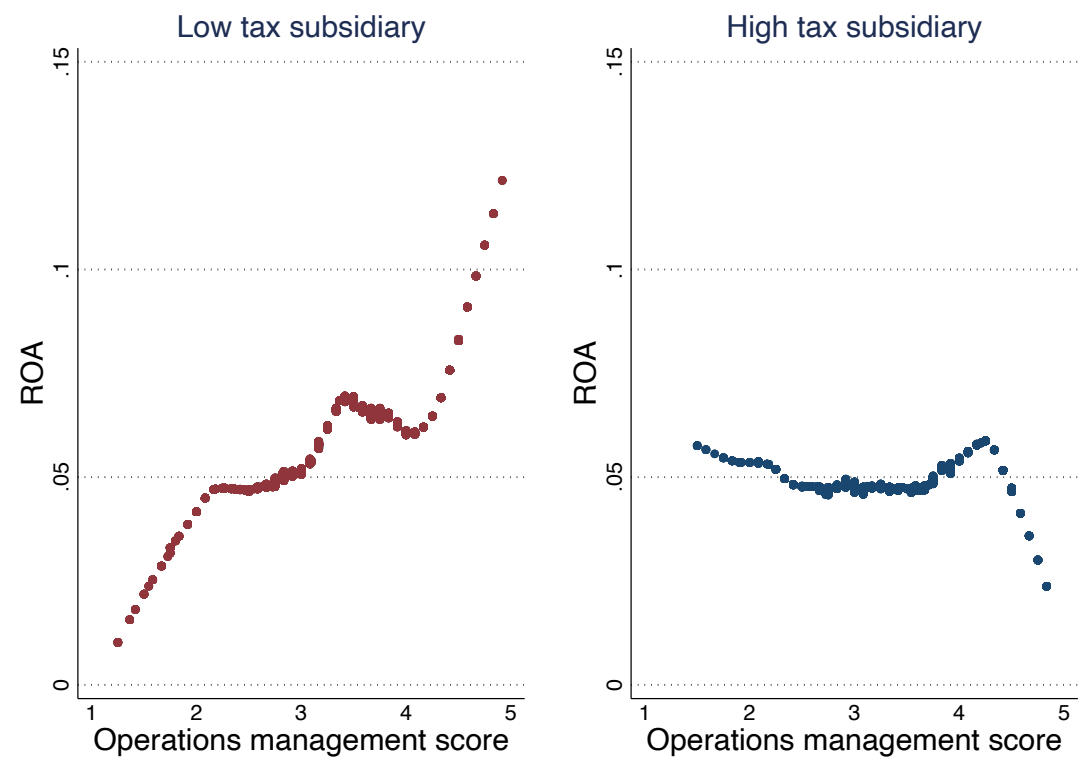

Note: Data from the World Management Survey and Orbis. Baseline sample includes only firms that for which we observe management scores and were directly matched in both WMS and Orbis. On the horizontal axis we have operations management, which is the average for the WMS operations management questions (including lean management, monitoring and target-setting). On the vertical axis we have ROA, which is the ratio of profit and loss to total assets. Low tax subsidiary are firms located in countries with below median statutory corporate tax rate for a given year. High tax subsidiary are firms located in countries with above median statutory corporate tax rate for a given year. The graphs present coefficients from local linear regressions run with bandwidth 0.5. 
Figure III: Within-MNE Relationship Between Management and ROA

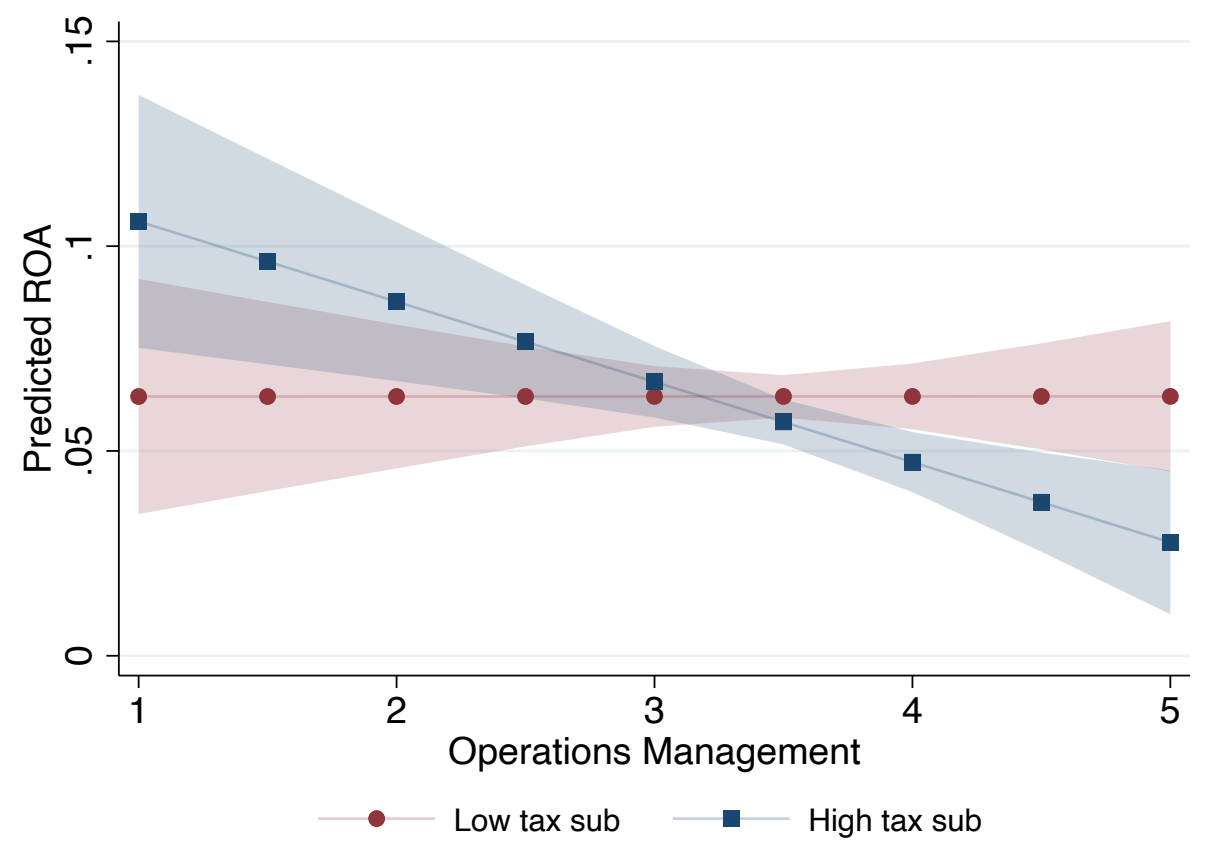

Note: Data from the World Management Survey and Orbis. Baseline sample includes only firms that for which we observe management scores and were directly matched in both WMS and Orbis. Here, we limit the sample to MNEs with at least two subsidiaries for which we observe management. The results presented in this graph are marginal effects from the regression of ROA on operations management score interacted with high tax subsidiary dummy using MNE fixed effects. Thus, they show within MNE variation. Each blue square corresponds to the predicted ROA at a given management level for firms located in high tax countries. Each red circle corresponds to the predicted ROA at a given management level for firms located in low tax countries. On the horizontal axis we have operations management score, which is the average for the WMS operations management questions (including lean management, monitoring and target-setting). On the vertical axis we have ROA which is the ratio of profit and loss to total assets. Low tax subsidiary are firms located in countries with below median statutory corporate tax rate for a given year. High tax subsidiary are firms located in countries with above median statutory corporate tax rate for a given year. 
Figure IV: Event Study: Tax Cuts and Reported Profits.

(a) Reported Profitability, formal vs informal

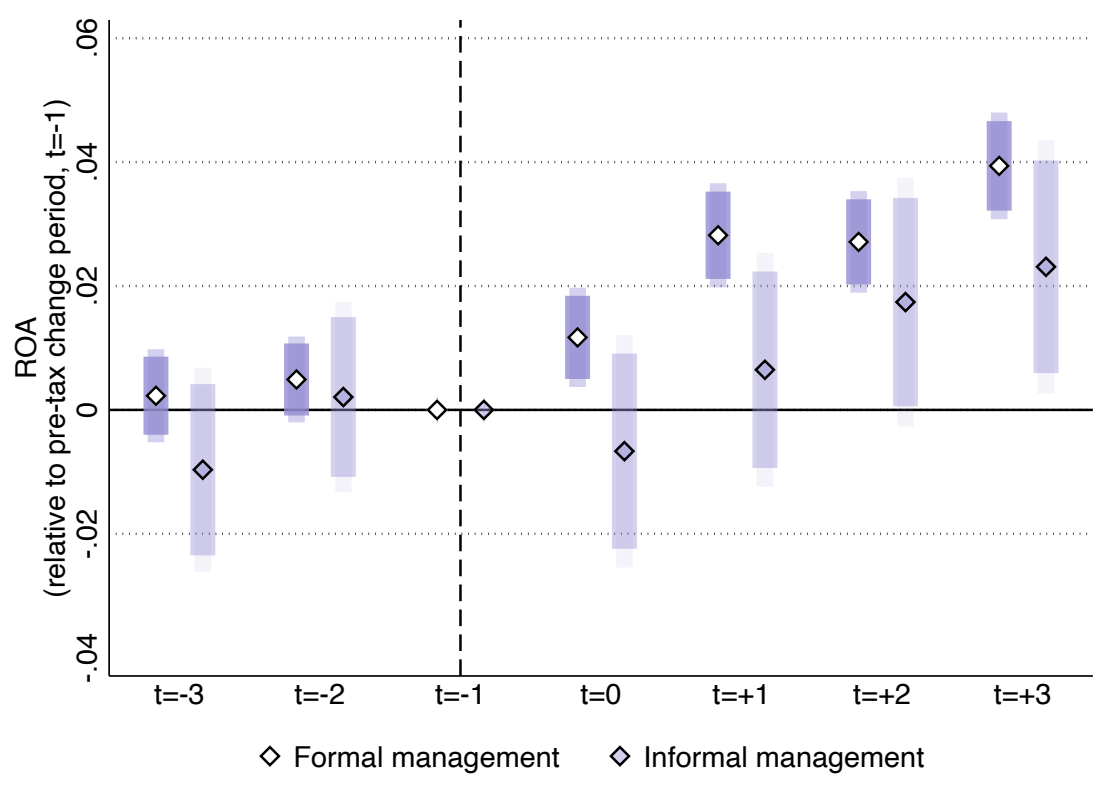

(b) Difference between formal and informal

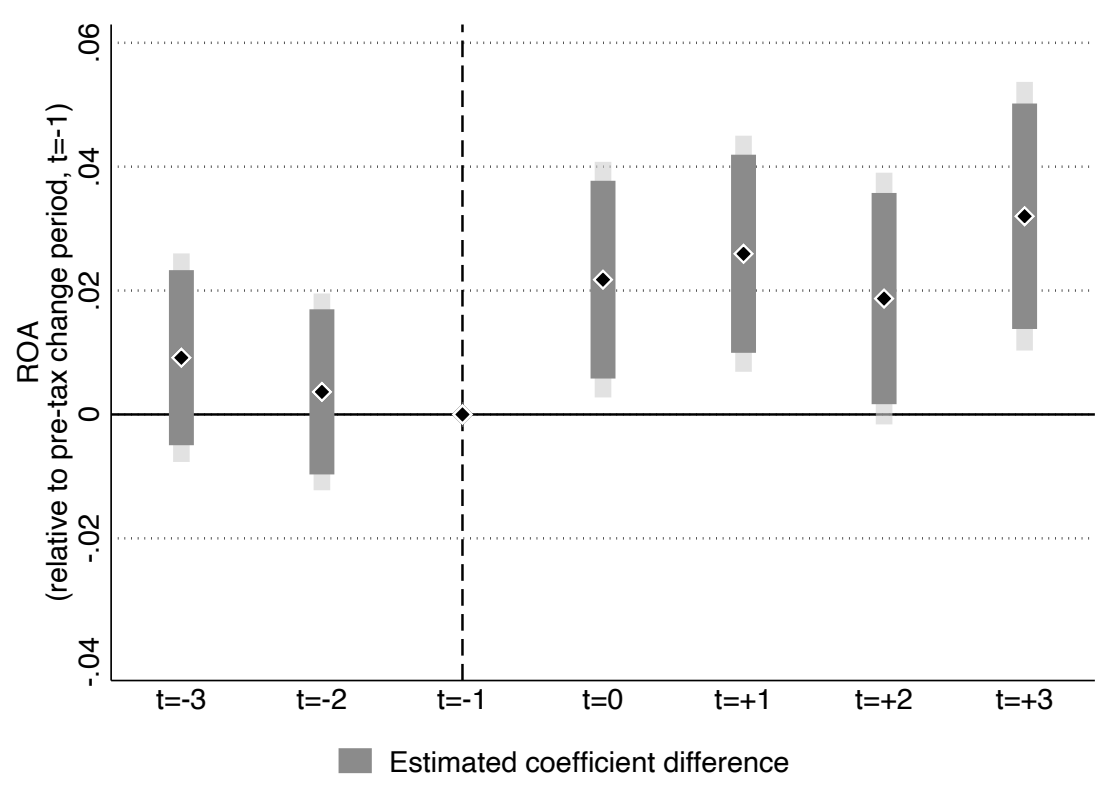

Note: Data from the World Management Survey and Orbis. This figure plots yearly coefficients from event study estimation, where the outcome variable is ROA (returns on assets). ROA is the ratio of profit and loss before taxes and total assets. White diamonds in Panel A correspond to coefficients for firms with formal management practices in place, where formal management is defined as a dummy equal to one when the average for the WMS operations management questions (including lean management, monitoring and target-setting) is 3 or above, on a scale of 1 to 5. Shaded diamonds in Panel A correspond to coefficients for firms with informal management (scores below 3 on the 1 to 5 scale). In Panel B, we plot the coefficients for the estimated difference between formal and informal management firms. 
Figure V: ROA and Operations Management in Low- and High-tax Country-Years by Aggressiveness
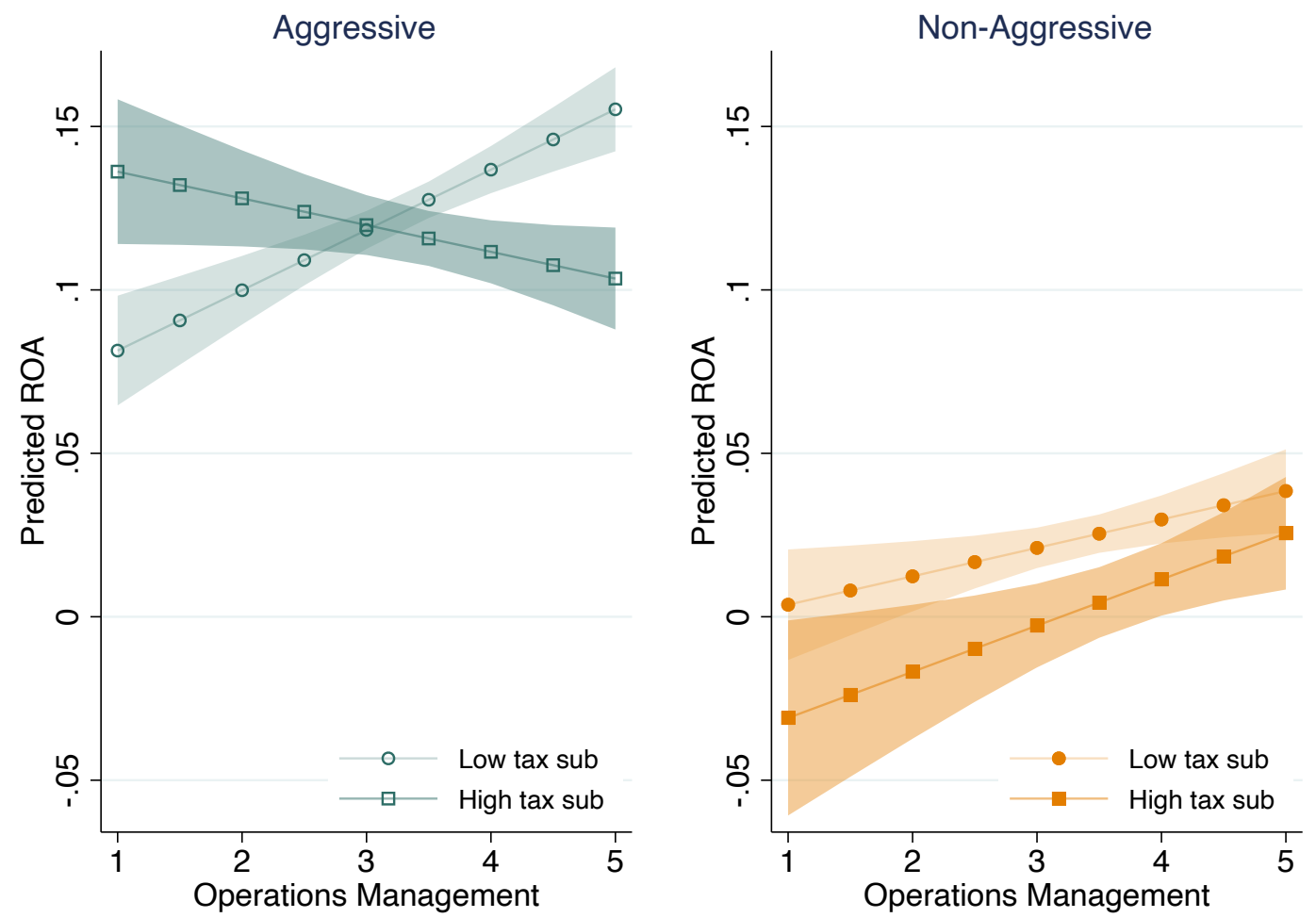

Note: Data from the World Management Survey and Orbis. Baseline sample includes only firms that for which we observe management scores and were directly matched in both WMS and Orbis. The results presented in this graph are marginal effects from the regression of ROA on operations management score by high vs. low corporate tax location. Panel (a) includes only firms classified as aggressive (book-tax differences above median). Panel (b) includes only firms classified as non-aggressive (book-tax differences below median). Each square corresponds to the predicted ROA at a given management level for firms located in high tax countries. Each circle corresponds to the predicted ROA at a given management level for firms located in low tax countries. Low tax subsidiary are firms located in countries with below median statutory corporate tax rate for a given year. High tax subsidiary are firms located in countries with above median statutory corporate tax rate for a given year. The operations management score is the average for the WMS operations management questions (including lean management, monitoring and target-setting). ROA is the ratio of profit and loss to total assets. 
Figure VI: Bunching Around Zero ROA
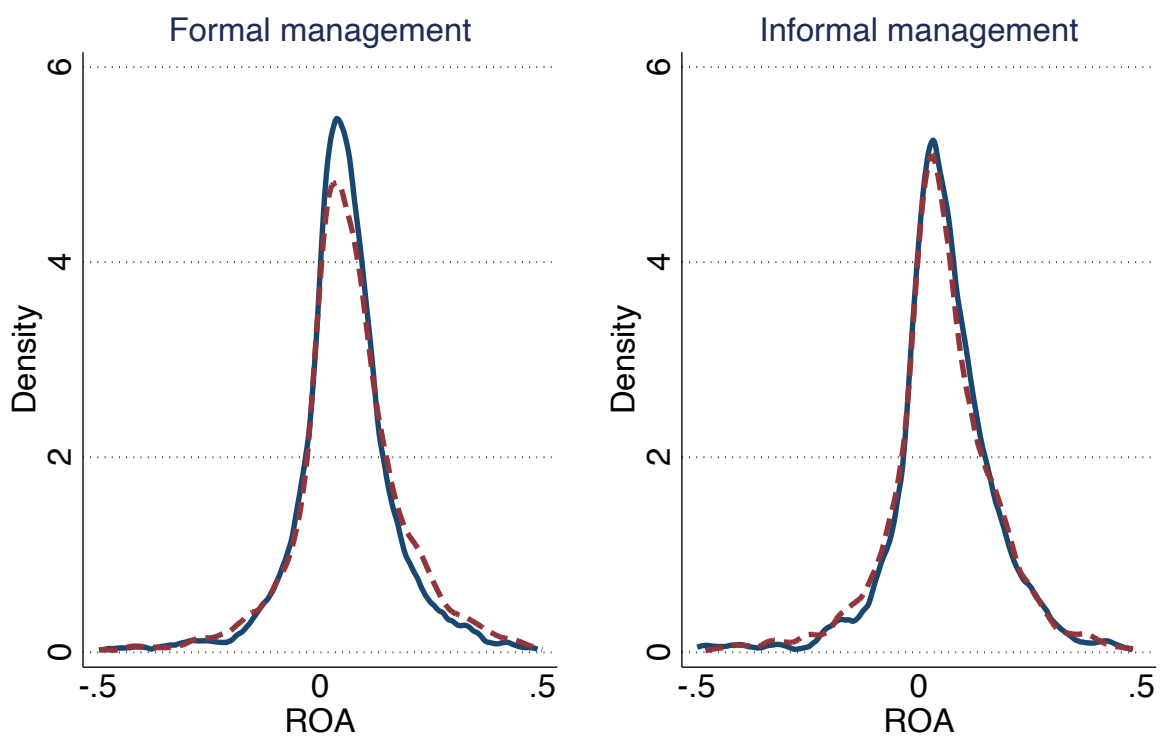

High tax

Low tax

Note: Data from the World Management Survey and Orbis. Baseline sample includes only firms that for which we observe management scores and were directly matched in both WMS and Orbis. We plot the distribution of ROA, which is the ratio of profit and loss to total assets. ROA restricted between -0.5 and 0.5. formal management is a dummy equal to one when the average for the WMS operations management questions (including lean management, monitoring and target-setting) is 3 or above, on a scale of 5 . High tax is a dummy equal to 1 when the firm is located in a country with above median statutory corporate tax rate. Hence, blue solid lines show the distribution of ROA for subsidiaries in high tax countries, while red dashed lines for subsidiaries in low tax countries. 
Figure VII: Bunching of ROA around Zero for Aggressive Firms by Management Type.

(a) Aggressive
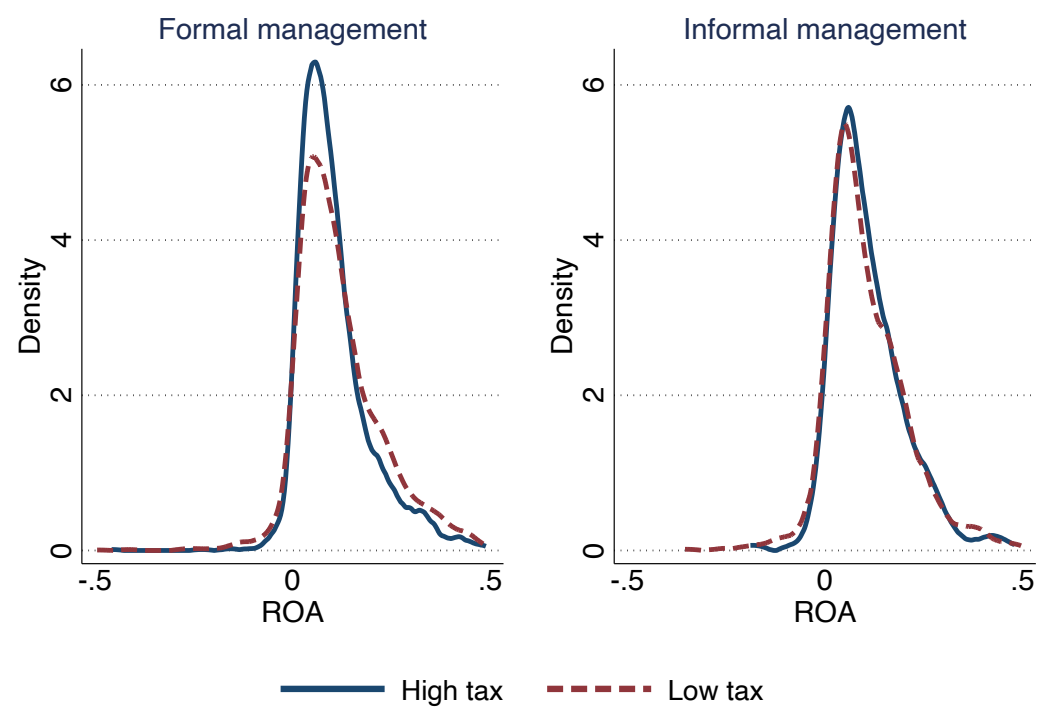

(b) Non-aggressive
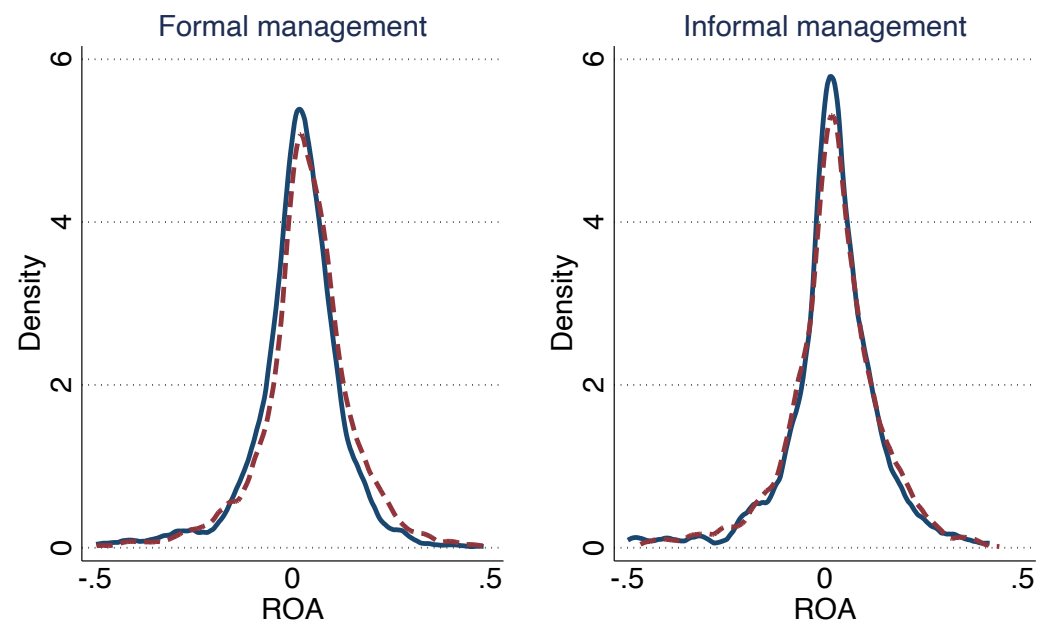

High tax

-ேー・- Low tax

Note: Data from the World Management Survey and Orbis. Static sample includes only firms that for which we observe management scores and were directly matched in both WMS and Orbis. We plot the distribution of ROA, which is the ratio of profit and loss to total assets. ROA restricted between -1 and 1. formal management is a dummy equal to one when the average for the WMS operations management questions (including lean management, monitoring and target-setting) is 3 or above, on a scale of 5 . High tax is a dummy equal to 1 when the firm is located in a country with above median statutory corporate tax rate. Hence, blue solid lines show the distribution of ROA for subsidiaries in high tax countries, while red dashed lines for subsidiaries in low tax countries. In Panel A we show the ROA distributions for aggressive firms and in Panel B for non-aggressive. Non-aggressive are firms with book tax difference (BTD) below median and Aggressive are firms with BTD above median. 
Figure VIII: Mechanisms: Management Practices and Firm Profitability for Aggressive and Non-aggressive firms
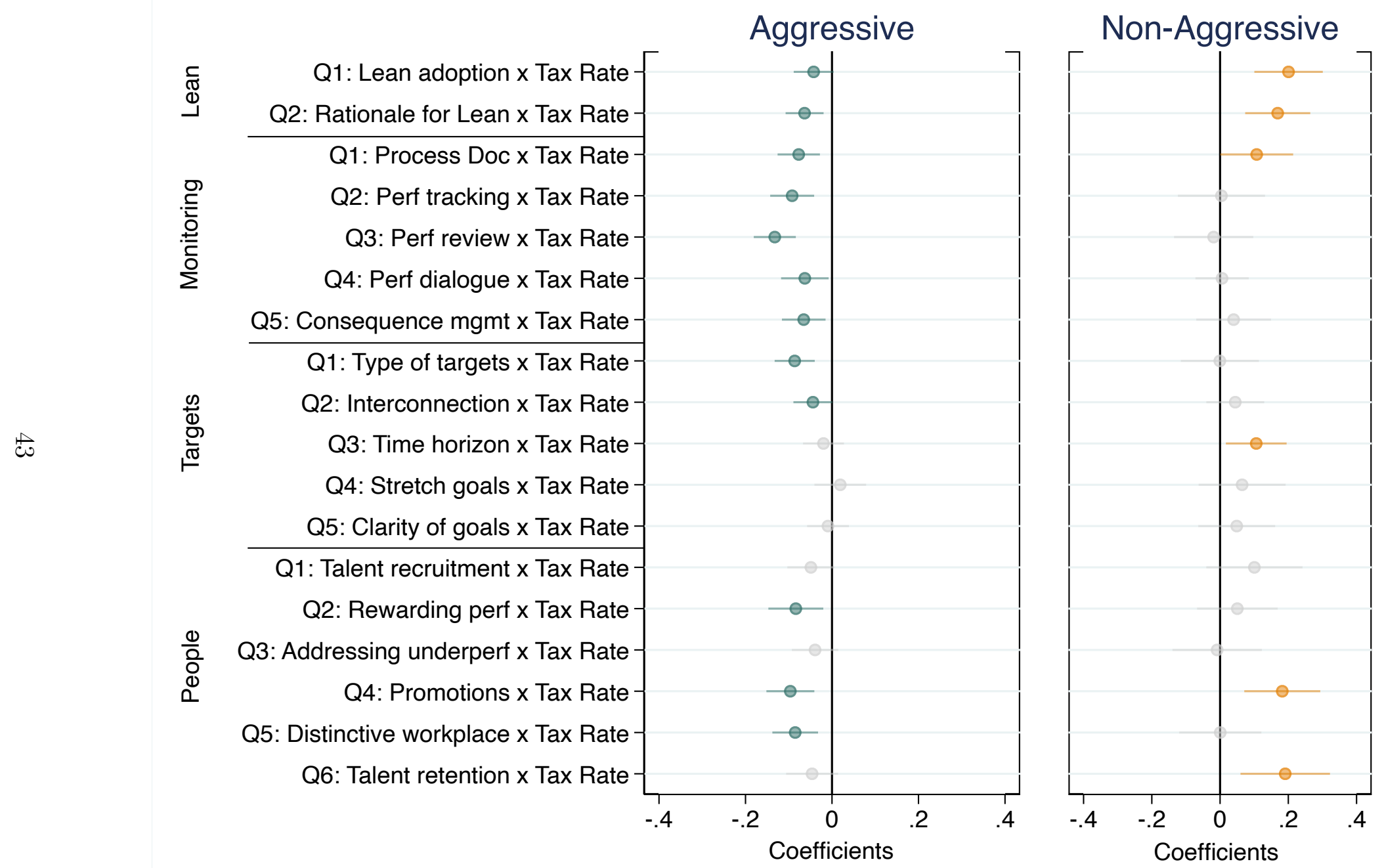

Note: Data from the World Management Survey and Orbis. This figure plots the interaction coefficients from a regression of profitability (ROA) on each of the 18 individual management topics, subsidiary corporate tax rates and controls for firm size (log of fixed assets, log of employment, $\log$ of number of subsidiaries) as well as year and industry fixed effects. We classify firms as "aggressive" if they have a subsidiary in a tax haven. Darker color markers indicate statistically significant coefficients (at the 5 percent level), and light gray markers indicate coefficients that are not significantly different from zero (at the 5 percent level). 


\section{Appendices}

\section{A Conceptual Framework}

Let all subsidiaries have a common objective function of after-tax profit maximisation achieved by maximizing production across all plants and minimizing tax liabilities. The manager at the $\mathrm{HQ}$ is responsible for the tax planning strategy of the entire corporate group. ${ }^{37}$ Let a firm have two subsidiaries, one in a high tax (with tax rate $\tau_{H}$ ) and one in a low tax (with tax rate $\tau_{L}$ ) location. The HQ manager wants to minimize its tax liabilities, by reallocating a share, $\alpha \in[0,1]$, of profits from the high tax location to the low tax location. Moving profits is costly and we assume that the cost of profit shifting $(c)$ increases in the amount of profits $(\pi)$ that a firm makes and in the share of profits $(\alpha)$ that a firm shifts at an increasing rate, such that $\frac{\partial c}{\partial \pi}>0, \frac{\partial c}{\partial \alpha}>0$, and $\frac{\partial^{2} c}{\partial \alpha^{2}}>0$ (consistent with Hines and Rice (1994); Huizinga et al. (2008)).

We assume that profits are an increasing function of the quality of management $(m)$, such that $\frac{\partial \pi(m)}{\partial m}>0$ (consistent with Bloom, Sadun and Van Reenen (2012)). We propose that the cost function that the HQ manager faces takes the form $c(\alpha, m, \pi(m))$. In particular, we include an additional factor: the quality of management of the MNE $(m>0)$. Firms with better management face lower costs for shifting profits: $\frac{d c}{d m}=\frac{\partial c}{\partial m}+\frac{\partial c}{\partial \pi} \frac{\partial \pi(m)}{\partial m}<0$. We assume that they have decreasing cost of shifting when the share of shifted profits increases, such that $\frac{\partial^{2} c}{\partial \alpha \partial m}<0$, and those that shift more profits in levels are also going to face decreasing costs, such that $\frac{\partial^{2} c}{\partial \alpha \partial \pi}<0$.

The firm is minimizing its tax liability:

$$
\min _{\alpha \in[0,1]} \tau_{H}(1-\alpha) \pi(m)+\tau_{L} \alpha \pi(m)+c(\alpha, m, \pi(m))
$$

The first order condition for this problem is: $\left(\tau_{L}-\tau_{H}\right) \pi(m)+\frac{\partial c}{\partial \alpha}=0$

We use this simple minimization problem to show how management affects the share of shifted profits; that is, the sign of $\frac{\partial \alpha *}{\partial m}$. Thus, we differentiate the FOC with respect to $\mathrm{m}$, which yields:

$$
\frac{\partial \alpha *}{\partial m}=\frac{-\frac{\partial^{2} c}{\partial \alpha \partial m}+\left(\tau_{H}-\tau_{L}\right) \frac{\partial \pi(m)}{\partial m}-\frac{\partial^{2} c}{\partial \alpha \partial \pi} \frac{\partial \pi(m)}{\partial m}}{\frac{\partial^{2} c}{\partial \alpha^{2}}}>0
$$

Proposition: Better management increases share of shifted profits $\alpha$.

\footnotetext{
${ }^{37}$ While a subsidiary can also be involved in tax planning decisions, we assume it is always in conjunction with the HQ as tax planning across borders — profit shifting — involves at least two entities located in different jurisdictions and requires a certain level of coordination.
} 


\section{B Additional Tables and Figures}

Table B1: Correlates of Management Practices.

\begin{tabular}{|c|c|c|c|c|}
\hline & z-management & $\begin{array}{c}(2) \\
\text { z-management }\end{array}$ & $\begin{array}{c}(3) \\
\text { Formal } \\
\text { management }\end{array}$ & $\begin{array}{c}(4) \\
\text { Formal } \\
\text { management }\end{array}$ \\
\hline \multicolumn{5}{|l|}{ Firm characteristics } \\
\hline $\operatorname{Ln}($ employment $)$ & $\begin{array}{c}0.011 \\
(0.007)\end{array}$ & $\begin{array}{c}0.010 \\
(0.007)\end{array}$ & $\begin{array}{c}0.002 \\
(0.003)\end{array}$ & $\begin{array}{c}0.001 \\
(0.003)\end{array}$ \\
\hline Ln(fixed assets) & $\begin{array}{c}0.005^{* *} \\
(0.002)\end{array}$ & $\begin{array}{c}0.005^{* *} \\
(0.002)\end{array}$ & $\begin{array}{c}0.002^{* *} \\
(0.001)\end{array}$ & $\begin{array}{c}0.002^{* *} \\
(0.001)\end{array}$ \\
\hline Ln(\# subsidiaries) & $\begin{array}{c}0.079^{* * *} \\
(0.012)\end{array}$ & $\begin{array}{c}0.051^{* * *} \\
(0.014)\end{array}$ & $\begin{array}{c}0.026^{* * *} \\
(0.005)\end{array}$ & $\begin{array}{l}0.011^{*} \\
(0.006)\end{array}$ \\
\hline Fixed asset growth & $\begin{array}{c}-0.001 \\
(0.065)\end{array}$ & $\begin{array}{l}-0.018 \\
(0.064)\end{array}$ & $\begin{array}{c}0.007 \\
(0.031)\end{array}$ & $\begin{array}{l}-0.001 \\
(0.031)\end{array}$ \\
\hline z-centralization & $\begin{array}{l}-0.012 \\
(0.023)\end{array}$ & $\begin{array}{l}-0.012 \\
(0.023)\end{array}$ & $\begin{array}{c}0.010 \\
(0.011)\end{array}$ & $\begin{array}{l}0.010 \\
(0.011)\end{array}$ \\
\hline \multicolumn{5}{|l|}{ Aggressiveness } \\
\hline BTD $>$ median & $\begin{array}{c}0.013 \\
(0.059)\end{array}$ & $\begin{array}{c}0.018 \\
(0.059)\end{array}$ & $\begin{array}{l}-0.004 \\
(0.027)\end{array}$ & $\begin{array}{l}-0.001 \\
(0.027)\end{array}$ \\
\hline Effective Tax Rate & $\begin{array}{l}-0.106 \\
(0.134)\end{array}$ & $\begin{array}{l}-0.110 \\
(0.133)\end{array}$ & $\begin{array}{c}-0.052 \\
(0.058)\end{array}$ & $\begin{array}{l}-0.053 \\
(0.058)\end{array}$ \\
\hline Book tax differences (median) & $\begin{array}{c}0.609 \\
(0.513)\end{array}$ & $\begin{array}{c}0.577 \\
(0.506)\end{array}$ & $\begin{array}{c}0.208 \\
(0.221)\end{array}$ & $\begin{array}{c}0.192 \\
(0.216)\end{array}$ \\
\hline Has a tax haven subsidiary & & $\begin{array}{c}0.300^{* * * *} \\
(0.061)\end{array}$ & & $\begin{array}{c}0.152^{* * * *} \\
(0.030)\end{array}$ \\
\hline $\begin{array}{l}\text { Tax Rate } \\
\text { Subsidiary Corp Tax (median) }\end{array}$ & $\begin{array}{c}0.535 \\
(1.757) \\
\end{array}$ & $\begin{array}{c}0.287 \\
(1.744) \\
\end{array}$ & $\begin{array}{c}0.901 \\
(0.800) \\
\end{array}$ & $\begin{array}{c}0.776 \\
(0.793) \\
\end{array}$ \\
\hline Observations & 1783 & 1783 & 1783 & 1783 \\
\hline
\end{tabular}

Note: Data from Orbis and the World Management Survey. This table shows coefficients from a regression of management practices on a set of explanatory variables. In all columns we average the explanatory variables across all time periods, unless otherwise specified. In columns 1 and 2 the outcome variable is z-management, which is the continuous operations management score. In Columns 3 and 4, the outcome variable is an indicator that takes a value of 1 when the average for the WMS operations management questions (including lean management, monitoring and target-setting) is 3 or above, on a scale of 1 to 5 . The WMS z-centralization measure is a score from 1 (most centralized) to 5 (most decentralized). BTD $>$ median is a dummy equal to 1 when book-tax difference is above median. Effective tax rate is a ratio fo tax liability to profit and loss before taxes. Subsidiary corp tax rate is the median statutory corporate tax rate in the country where a subsidiary is operating. All specifications include country and year fixed effects. Standard errors are robust in all columns. 
Figure B1: Performance and Operations Management in Low- and High-tax Country-years.
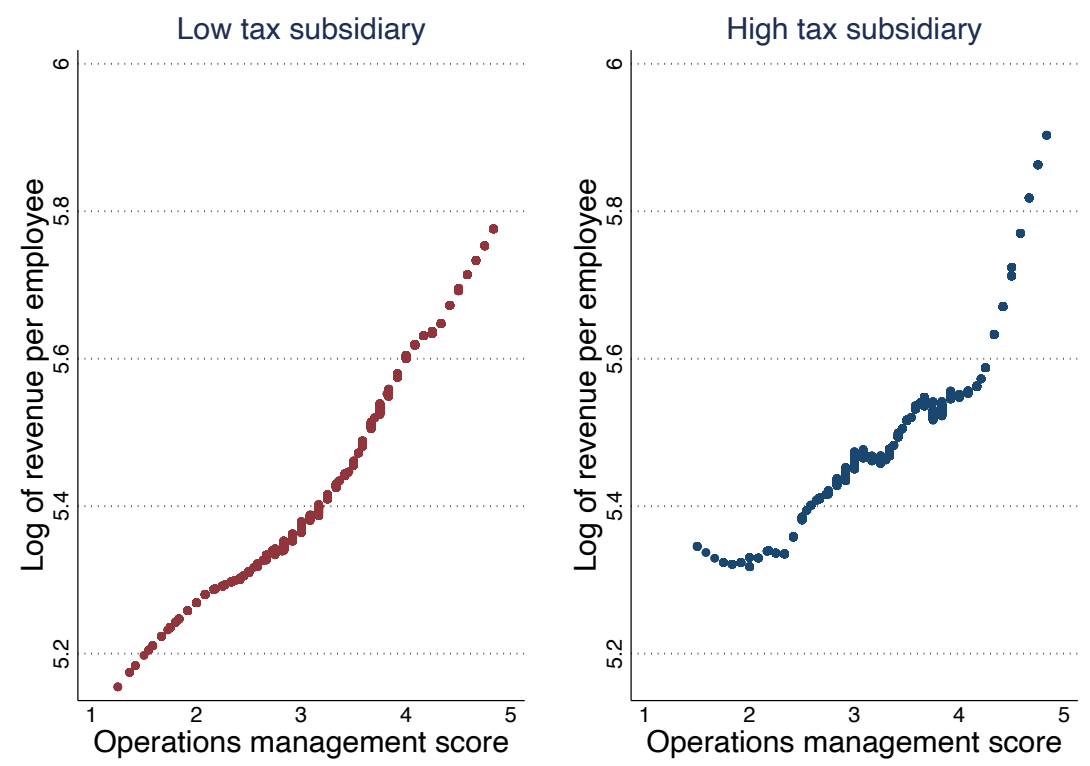

Note: Data from the World Management Survey and Orbis. Baseline sample includes only firms that for which we observe management scores and were directly matched in both WMS and Orbis. On the horizontal axis we have operations management, which is the average for the WMS operations management questions (including lean management, monitoring and target-setting). On the vertical axis we have log of revenue (sales) per employee. Low tax subsidiary are firms located in countries with below median statutory corporate tax rate for a given year. High tax subsidiary are firms located in countries with above median statutory corporate tax rate for a given year. The graphs present coefficients from local linear regressions run with bandwidth 0.5 . 
Table B2: Pre-post Summary Table, Event Study Sample, Sales per Employee.

\begin{tabular}{|c|c|c|c|c|c|c|c|c|c|}
\hline \multirow{2}{*}{$\begin{array}{l}\text { Dependent variable: } \\
\ln \text { (sales per employee) }\end{array}$} & \multicolumn{3}{|c|}{ All firms } & \multicolumn{3}{|c|}{ Aggressive firms } & \multicolumn{3}{|c|}{ Non-Aggressive firms } \\
\hline & $(1)$ & $(2)$ & $(3)$ & $(4)$ & $(5)$ & (6) & $(7)$ & (8) & (9) \\
\hline Formal management $=1$ & $\begin{array}{c}0.060 \\
(0.142)\end{array}$ & $\begin{array}{c}0.051 \\
(0.111)\end{array}$ & & $\begin{array}{c}0.052 \\
(0.157)\end{array}$ & $\begin{array}{c}0.045 \\
(0.121)\end{array}$ & & $\begin{array}{c}0.063 \\
(0.125)\end{array}$ & $\begin{array}{c}0.078 \\
(0.110)\end{array}$ & \\
\hline POST tax $\mathrm{cut}=1$ & $\begin{array}{c}0.183 \\
(0.111)\end{array}$ & $\begin{array}{l}0.157^{*} \\
(0.088)\end{array}$ & $\begin{array}{c}0.071 \\
(0.054)\end{array}$ & $\begin{array}{c}0.247^{* *} \\
(0.125)\end{array}$ & $\begin{array}{l}0.222^{* *} \\
(0.101)\end{array}$ & $\begin{array}{c}0.119 * * \\
(0.060)\end{array}$ & $\begin{array}{c}-0.180^{* *} \\
(0.083)\end{array}$ & $\begin{array}{c}-0.305^{* * *} \\
(0.108)\end{array}$ & $\begin{array}{c}-0.293^{* * *} \\
(0.096)\end{array}$ \\
\hline $\begin{array}{l}\text { Formal management }=1 \\
\times \text { POST tax } \text { cut }=1\end{array}$ & $\begin{array}{l}-0.021 \\
(0.136)\end{array}$ & $\begin{array}{l}-0.028 \\
(0.117)\end{array}$ & $\begin{array}{c}0.074 \\
(0.057)\end{array}$ & $\begin{array}{l}-0.068 \\
(0.150)\end{array}$ & $\begin{array}{l}-0.062 \\
(0.128)\end{array}$ & $\begin{array}{c}0.044 \\
(0.062)\end{array}$ & $\begin{array}{c}0.094 \\
(0.110)\end{array}$ & $\begin{array}{c}0.086 \\
(0.112)\end{array}$ & $\begin{array}{c}0.154 \\
(0.112)\end{array}$ \\
\hline Year FE & $\checkmark$ & $\checkmark$ & $\checkmark$ & $\checkmark$ & $\checkmark$ & $\checkmark$ & $\checkmark$ & $\checkmark$ & $\checkmark$ \\
\hline Country FE & $\checkmark$ & $\checkmark$ & $\checkmark$ & $\checkmark$ & $\checkmark$ & $\checkmark$ & $\checkmark$ & $\checkmark$ & $\checkmark$ \\
\hline Firm controls & & $\checkmark$ & $\checkmark$ & & $\checkmark$ & $\checkmark$ & & $\checkmark$ & $\checkmark$ \\
\hline Macro controls & & $\checkmark$ & $\checkmark$ & & $\checkmark$ & $\checkmark$ & & $\checkmark$ & $\checkmark$ \\
\hline MNE FE & & & $\checkmark$ & & & $\checkmark$ & & & $\checkmark$ \\
\hline Observations & 65131 & 55803 & 55803 & 61622 & 52939 & 52939 & 3509 & 2864 & 2864 \\
\hline \# firms & 11047 & 11047 & 11047 & 10490 & 10490 & 10490 & 557 & 557 & 557 \\
\hline Dependent Variable Mean & 12.811 & 12.811 & 12.811 & 12.819 & 12.819 & 12.819 & 12.671 & 12.671 & 12.671 \\
\hline
\end{tabular}

Note: Data from Orbis and the World Management Survey. This table includes only the firms in the Event Study sample, which includes all subsidiaries belonging to an MNE that has at least one plant observed in the WMS. Management data is then averaged across all subsidiaries within an MNE. Aggressive firms are defined as having a subsidiary in a tax haven. Non-aggressive firms are defined as not having any subsidiaries in a tax haven. The event considered here is firms that experienced one tax rate cut during the sample period. POST is a dummy equal to 1 in the years after the tax rate cut. The outcome variable in all columns is ROA (returns on assets) which is the ratio of profit and loss before taxes and total assets. Firm controls include log of employment, log of fixed assets and log of number of subsidiaries in the MNE. Standard errors are clustered at the MNE level in Columns 3, 6 and 9 and robust otherwise. 
Figure B2: Event Study: Tax Cuts and Productivity.

(a) Productivity, formal vs informal

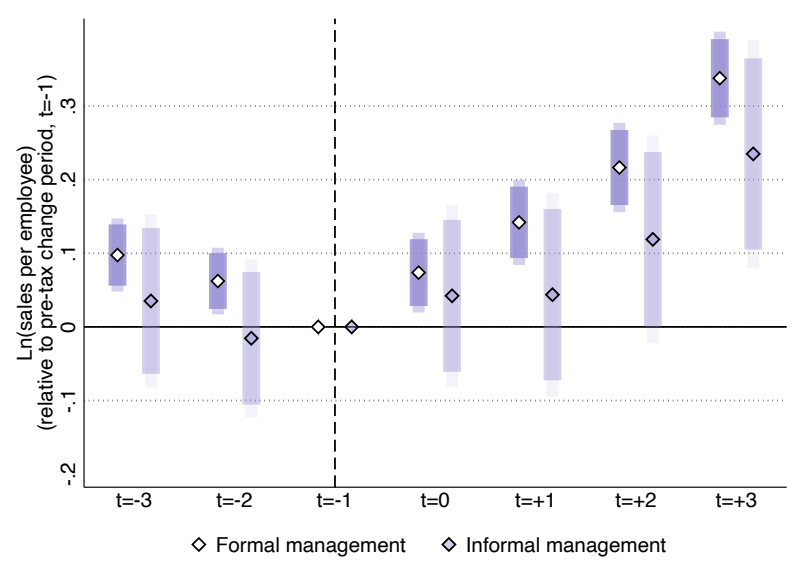

(b) Difference between formal and informal

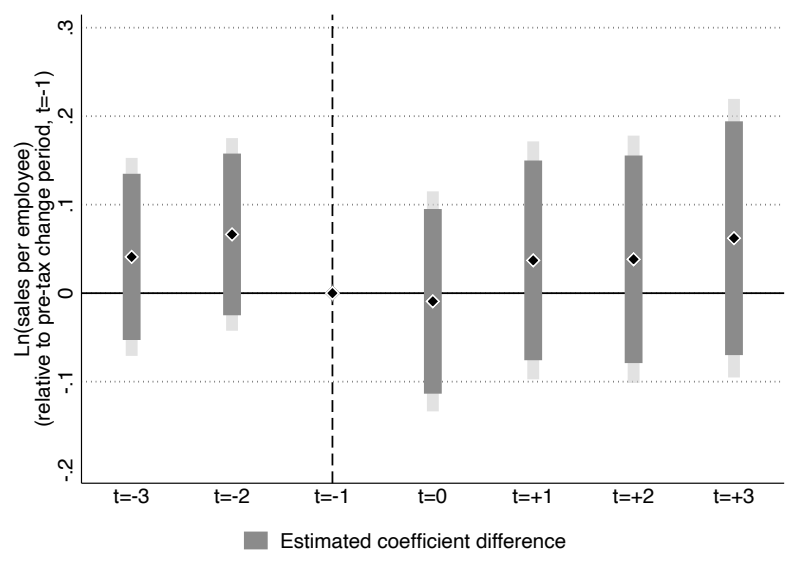

Note: Data from the World Management Survey and Orbis. This figure plots yearly coefficients from event study estimation, where the outcome variable is performance (log of sales per employee). White diamonds in Panel A correspond to coefficients for firms with formal management practices in place, where formal management is defined as a dummy equal to one when the average for the WMS operations management questions (including lean management, monitoring and target-setting) is 3 or above, on a scale of 1 to 5 . Shaded diamonds in Panel A correspond to coefficients for firms with informal management (scores below 3 on the 1 to 5 scale). In Panel B, we plot the coefficients for the estimated difference between formal and informal management firms. 
A simple comparison of ROA with EBIT can shed some light on the use of debt shifting by MNEs. Again with the caveat that data is extremely limited for this exercise, we compare firms that have made data on both their ROA (from profit and loss statement) and EBIT (from income statement) available to shed some light on the use of interest deductability by MNEs (Table B3). For this selected sample of firms, there is limited evidence that interest deductability plays a role. Magnitude-size, the interaction coefficient for EBIT as an outcome variable in Column 4 is smaller than the coefficient for ROA in Column 3, but not statistically significant.

Table B3: Understanding the Channels: Alternative Measures of Profitability.

\begin{tabular}{|c|c|c|c|c|c|c|c|}
\hline & $\begin{array}{c}(1) \\
\mathrm{ROA}\end{array}$ & $\begin{array}{c}(2) \\
\text { ROA* }^{*}\end{array}$ & $\begin{array}{c}(3) \\
\mathrm{ROA}\end{array}$ & $\begin{array}{c}(4) \\
\text { EBIT }\end{array}$ & $\begin{array}{c}(5) \\
\text { EBITDA }\end{array}$ & $\begin{array}{c}(6) \\
\text { Depreciation }\end{array}$ & $\begin{array}{c}(7) \\
\text { ETR }\end{array}$ \\
\hline Formal management $=1$ & $\begin{array}{c}0.041^{* * *} \\
(0.015)\end{array}$ & $\begin{array}{c}0.040^{* * *} \\
(0.016)\end{array}$ & $\begin{array}{c}0.084^{* *} \\
(0.036)\end{array}$ & $\begin{array}{l}0.074^{* *} \\
(0.033)\end{array}$ & $\begin{array}{l}0.071^{* *} \\
(0.032)\end{array}$ & $\begin{array}{l}-0.008 \\
(0.007)\end{array}$ & $\begin{array}{l}0.059^{*} \\
(0.035)\end{array}$ \\
\hline Subsidiary corp tax rate & $\begin{array}{c}-0.236^{* * *} \\
(0.075)\end{array}$ & $\begin{array}{c}-0.221^{* * *} \\
(0.079)\end{array}$ & $\begin{array}{c}0.221 \\
(0.156)\end{array}$ & $\begin{array}{c}0.121 \\
(0.138)\end{array}$ & $\begin{array}{c}0.072 \\
(0.133)\end{array}$ & $\begin{array}{c}-0.067^{* *} \\
(0.032)\end{array}$ & $\begin{array}{c}0.848^{* * *} \\
(0.216)\end{array}$ \\
\hline $\begin{array}{l}\text { Formal management }=1 \\
\quad \times \text { Subsidiary corp tax rate }\end{array}$ & $\begin{array}{c}-0.121^{* *} \\
(0.054)\end{array}$ & $\begin{array}{c}-0.117^{* *} \\
(0.056)\end{array}$ & $\begin{array}{r}-0.208^{*} \\
(0.122)\end{array}$ & $\begin{array}{l}-0.182 \\
(0.112)\end{array}$ & $\begin{array}{l}-0.159 \\
(0.107)\end{array}$ & $\begin{array}{l}0.043^{*} \\
(0.024)\end{array}$ & $\begin{array}{c}-0.296^{* *} \\
(0.131)\end{array}$ \\
\hline Country FE & $\checkmark$ & $\checkmark$ & $\checkmark$ & $\checkmark$ & $\checkmark$ & $\checkmark$ & $\checkmark$ \\
\hline Year FE & $\checkmark$ & $\checkmark$ & $\checkmark$ & $\checkmark$ & $\checkmark$ & $\checkmark$ & $\checkmark$ \\
\hline Firm controls & $\checkmark$ & $\checkmark$ & $\checkmark$ & $\checkmark$ & $\checkmark$ & $\checkmark$ & $\checkmark$ \\
\hline Observations & 16076 & 14129 & 4741 & 4741 & 4741 & 4741 & 15216 \\
\hline \# firms & 1783 & 1783 & 517 & 517 & 517 & 517 & 1750 \\
\hline Dependent Variable Mean & 0.058 & 0.055 & 0.059 & 0.061 & 0.103 & 0.042 & 0.187 \\
\hline
\end{tabular}

Note: Data from Orbis and the World Management Survey. WMS sample includes only firms for which we observe management scores and were directly matched in both WMS and Orbis. Formal management $=1$ is a dummy equal to one when the average for the WMS operations management questions (including lean management, monitoring and target-setting) is 3 or above, on a scale of 1 to 5 . Subsidiary corp tax rate is the annual statutory corporate tax rate in the country where a firm is operating. The outcome variable in Columns (1)-(3) is Returns on Assets (ROA) which is the ratio of profit and loss before taxes and total assets. ROA in Columns (1) and (3) is calculated using contemporaneous profit and loss before taxes and assets, while Column (2) uses lagged assets in the denominator. In Column (4) outcome variable is EBIT, defined as earnings before interest and tax. Column (5) outcome is EBITDA, defined as earnings before interest, tax and depreciation. Column (6) outcome variable is depreciation, calculated as the difference between EBITA and EBIT. Column (7) outcome is Effective Tax Rate (ETR), calculated as the ratio of tax liability to profit and loss before taxes. In Column (3), we limit the sample to only firms for which we observe both EBIT and EBITDA as a reference point. All specifications include country and year fixed effects. Firm controls include log of employment, log of fixed assets and log of number of subsidiaries in the MNE. Standard errors are robust in all columns. 
Table B4: Individual Management Practices and Tax Rate: Interaction Coefficients.

Table of coefficients: each cell is a unique regression.

\begin{tabular}{|c|c|c|c|c|c|c|}
\hline & \multicolumn{2}{|c|}{ All } & \multicolumn{2}{|c|}{ Aggressive } & \multicolumn{2}{|c|}{ Non-Aggressive } \\
\hline & \multicolumn{2}{|c|}{$\mathrm{ROA}$} & \multicolumn{2}{|c|}{ ROA } & \multicolumn{2}{|c|}{ ROA } \\
\hline & (1) & (2) & (3) & $(4)$ & $(5)$ & $(6)$ \\
\hline Z-Index: Lean ops $\times$ Tax Rate & $\begin{array}{l}-0.015 \\
(0.022)\end{array}$ & $\begin{array}{l}-0.007 \\
(0.022)\end{array}$ & $\begin{array}{c}-0.056^{* *} \\
(0.024)\end{array}$ & $\begin{array}{c}-0.089^{* * *} \\
(0.026)\end{array}$ & $\begin{array}{c}0.220^{* * *} \\
(0.050)\end{array}$ & $\begin{array}{l}0.076^{* *} \\
(0.031)\end{array}$ \\
\hline Q1: Lean adoption $\times$ Tax Rate & $\begin{array}{l}-0.001 \\
(0.021)\end{array}$ & $\begin{array}{l}0.006 \\
(0.021)\end{array}$ & $\begin{array}{l}-0.042^{*} \\
(0.024)\end{array}$ & $\begin{array}{c}-0.065^{* *} \\
(0.026)\end{array}$ & $\begin{array}{c}0.201 * * * \\
(0.051)\end{array}$ & $\begin{array}{c}0.067^{* *} \\
(0.029)\end{array}$ \\
\hline Q2: Rationale for Lean $\times$ Tax Rate & $\begin{array}{l}-0.030 \\
(0.021)\end{array}$ & $\begin{array}{l}-0.022 \\
(0.021)\end{array}$ & $\begin{array}{c}-0.063^{* * *} \\
(0.022)\end{array}$ & $\begin{array}{c}-0.097^{* * *} \\
(0.025)\end{array}$ & $\begin{array}{c}0.169^{* * *} \\
(0.049)\end{array}$ & $\begin{array}{c}0.067^{* *} \\
(0.029)\end{array}$ \\
\hline Z-Index: Monitoring $\times$ Tax Rate & $\begin{array}{c}-0.074^{* * *} \\
(0.022)\end{array}$ & $\begin{array}{c}-0.068^{* * *} \\
(0.022)\end{array}$ & $\begin{array}{c}-0.107^{* * *} \\
(0.025)\end{array}$ & $\begin{array}{c}-0.121^{* * *} \\
(0.027)\end{array}$ & $\begin{array}{l}0.041 \\
(0.056)\end{array}$ & $\begin{array}{l}-0.003 \\
(0.029)\end{array}$ \\
\hline Q1: Process Doc $\times$ Tax Rate & $\begin{array}{c}-0.045^{* *} \\
(0.022)\end{array}$ & $\begin{array}{l}-0.037 \\
(0.023)\end{array}$ & $\begin{array}{c}-0.077^{* * *} \\
(0.025)\end{array}$ & $\begin{array}{l}-0.028 \\
(0.025)\end{array}$ & $\begin{array}{c}0.107^{* *} \\
(0.055)\end{array}$ & $\begin{array}{c}0.002 \\
(0.028)\end{array}$ \\
\hline Q2: Perf tracking $\times$ Tax Rate & $\begin{array}{c}-0.059^{* *} \\
(0.024)\end{array}$ & $\begin{array}{c}-0.053^{* *} \\
(0.024)\end{array}$ & $\begin{array}{c}-0.092^{* * *} \\
(0.026)\end{array}$ & $\begin{array}{c}-0.125^{* * *} \\
(0.026)\end{array}$ & $\begin{array}{c}0.004 \\
(0.065)\end{array}$ & $\begin{array}{l}0.053^{*} \\
(0.032)\end{array}$ \\
\hline Q3: Perf review $\times$ Tax Rate & $\begin{array}{c}-0.100^{* * *} \\
(0.023)\end{array}$ & $\begin{array}{c}-0.096^{* * *} \\
(0.022)\end{array}$ & $\begin{array}{c}-0.132^{* * *} \\
(0.025)\end{array}$ & $\begin{array}{c}-0.123^{* * *} \\
(0.027)\end{array}$ & $\begin{array}{l}-0.019 \\
(0.059)\end{array}$ & $\begin{array}{c}-0.076^{* *} \\
(0.032)\end{array}$ \\
\hline Q4: Perf dialogue $\times$ Tax Rate & $\begin{array}{c}-0.048^{* *} \\
(0.024)\end{array}$ & $\begin{array}{c}-0.045^{*} \\
(0.024)\end{array}$ & $\begin{array}{c}-0.063^{* *} \\
(0.028)\end{array}$ & $\begin{array}{c}-0.152^{* * *} \\
(0.029)\end{array}$ & $\begin{array}{c}0.006 \\
(0.040)\end{array}$ & $\begin{array}{c}0.070^{* *} \\
(0.032)\end{array}$ \\
\hline Q5: Consequence mgmt $\times$ Tax Rate & $\begin{array}{c}-0.048^{* *} \\
(0.023)\end{array}$ & $\begin{array}{c}-0.040^{*} \\
(0.023)\end{array}$ & $\begin{array}{c}-0.065^{* *} \\
(0.026)\end{array}$ & $\begin{array}{c}-0.056^{* *} \\
(0.028)\end{array}$ & $\begin{array}{c}0.040 \\
(0.056)\end{array}$ & $\begin{array}{c}-0.054^{*} \\
(0.028)\end{array}$ \\
\hline Z-Index: Targets $\times$ Tax Rate & $\begin{array}{l}-0.011 \\
(0.025)\end{array}$ & $\begin{array}{l}-0.006 \\
(0.025)\end{array}$ & $\begin{array}{c}-0.048^{*} \\
(0.028)\end{array}$ & $\begin{array}{c}-0.110^{* * *} \\
(0.031)\end{array}$ & $\begin{array}{c}0.107^{* *} \\
(0.054)\end{array}$ & $\begin{array}{c}0.051 \\
(0.034)\end{array}$ \\
\hline Q1: Type of targets $\times$ Tax Rate & $\begin{array}{c}-0.065^{* * *} \\
(0.022)\end{array}$ & $\begin{array}{c}-0.062^{* * *} \\
(0.022)\end{array}$ & $\begin{array}{c}-0.086^{* * *} \\
(0.024)\end{array}$ & $\begin{array}{c}-0.070^{* * *} \\
(0.026)\end{array}$ & $\begin{array}{l}-0.001 \\
(0.058)\end{array}$ & $\begin{array}{l}-0.047 \\
(0.029)\end{array}$ \\
\hline Q2: Interconnection $\times$ Tax Rate & $\begin{array}{l}-0.007 \\
(0.020)\end{array}$ & $\begin{array}{c}-0.001 \\
(0.020)\end{array}$ & $\begin{array}{l}-0.044^{*} \\
(0.023)\end{array}$ & $\begin{array}{l}-0.043 \\
(0.026)\end{array}$ & $\begin{array}{c}0.045 \\
(0.043)\end{array}$ & $\begin{array}{c}0.029 \\
(0.025)\end{array}$ \\
\hline Q3: Time horizon $\times$ Tax Rate & $\begin{array}{l}-0.001 \\
(0.022)\end{array}$ & $\begin{array}{c}0.004 \\
(0.021)\end{array}$ & $\begin{array}{l}-0.020 \\
(0.024)\end{array}$ & $\begin{array}{c}-0.091 * * * \\
(0.026)\end{array}$ & $\begin{array}{c}0.106^{* *} \\
(0.045)\end{array}$ & $\begin{array}{c}0.045 \\
(0.030)\end{array}$ \\
\hline Q4: Stretch goals $\times$ Tax Rate & $\begin{array}{l}0.047^{*} \\
(0.028)\end{array}$ & $\begin{array}{l}0.050^{*} \\
(0.027)\end{array}$ & $\begin{array}{c}0.019 \\
(0.030)\end{array}$ & $\begin{array}{c}-0.076^{* *} \\
(0.030)\end{array}$ & $\begin{array}{l}0.065 \\
(0.065)\end{array}$ & $\begin{array}{c}0.094^{* * *} \\
(0.036)\end{array}$ \\
\hline Q5: Clarity of goals $\times$ Tax Rate & $\begin{array}{l}-0.010 \\
(0.022)\end{array}$ & $\begin{array}{l}-0.007 \\
(0.022)\end{array}$ & $\begin{array}{l}-0.009 \\
(0.025)\end{array}$ & $\begin{array}{c}-0.063^{* *} \\
(0.028)\end{array}$ & $\begin{array}{c}0.049 \\
(0.057)\end{array}$ & $\begin{array}{c}0.030 \\
(0.030)\end{array}$ \\
\hline Observations & 16057 & 16057 & 11752 & 6737 & 4305 & 8465 \\
\hline \# firms & 1781 & 1781 & 1261 & 1512 & 520 & 1588 \\
\hline Dependent Variable Mean & 0.058 & 0.058 & 0.063 & 0.122 & 0.044 & 0.017 \\
\hline Aggressiveness measure & & & Tax Haven & BTD & Tax Haven & BTD \\
\hline Country FE & $\checkmark$ & $\checkmark$ & $\checkmark$ & $\checkmark$ & $\checkmark$ & $\checkmark$ \\
\hline Year FE & $\checkmark$ & $\checkmark$ & $\checkmark$ & $\checkmark$ & $\checkmark$ & $\checkmark$ \\
\hline Firm controls & & $\checkmark$ & $\checkmark$ & $\checkmark$ & $\checkmark$ & $\checkmark$ \\
\hline
\end{tabular}

Note: Data from Orbis and the World Management Survey. Tax rate is the statutory corporate tax rate in the country where a firm is operating. The definition of each management practice is in Table C1. The outcome variable in all columns is ROA (returns on assets) which is the ratio of profit and loss before taxes and total assets. In columns 3 and 4 aggressive firms are those with tax haven as part of their ownership structure or those with above median 5 pook tax difference (BTD) respectively. In columns 5 and 6 non-aggressive firms are those without tax havens as part of their ownership structure or those with below median book tax difference (BTD) respectively. Firm controls include log of employment, log of fixed assets and log of number of subsidiaries in the MNE. Standard errors are robust in all columns. 
Table B5: Individual Management Practices and Tax Rate: Interaction Coefficients.

Table of coefficients: each cell is a unique regression

\begin{tabular}{|c|c|c|c|c|c|c|}
\hline & \multicolumn{2}{|c|}{ All } & \multicolumn{2}{|c|}{ Aggressive } & \multicolumn{2}{|c|}{ Non-Aggressive } \\
\hline & \multicolumn{2}{|c|}{ ROA } & \multicolumn{2}{|c|}{$\mathrm{ROA}$} & \multicolumn{2}{|c|}{ ROA } \\
\hline & (1) & $(2)$ & (3) & (4) & (5) & (6) \\
\hline Z-Index: People $\times$ Tax Rate & $\begin{array}{c}-0.039 * \\
(0.023)\end{array}$ & $\begin{array}{c}-0.038^{*} \\
(0.023)\end{array}$ & $\begin{array}{c}-0.099 * * * \\
(0.026)\end{array}$ & $\begin{array}{c}-0.101^{* * *} \\
(0.031)\end{array}$ & $\begin{array}{l}0.096^{*} \\
(0.053)\end{array}$ & $\begin{array}{c}0.044 \\
(0.029)\end{array}$ \\
\hline Q1: Talent recruitment $\times$ Tax Rate & $\begin{array}{c}-0.054^{* *} \\
(0.021)\end{array}$ & $\begin{array}{c}-0.051^{* *} \\
(0.021)\end{array}$ & $\begin{array}{c}-0.089^{* * *} \\
(0.023)\end{array}$ & $\begin{array}{c}-0.096^{* * *} \\
(0.027)\end{array}$ & $\begin{array}{c}0.017 \\
(0.059)\end{array}$ & $\begin{array}{c}0.009 \\
(0.028)\end{array}$ \\
\hline Q2: Rewarding perf $\times$ Tax Rate & $\begin{array}{l}-0.024 \\
(0.025)\end{array}$ & $\begin{array}{l}-0.022 \\
(0.024)\end{array}$ & $\begin{array}{c}-0.063^{* *} \\
(0.028)\end{array}$ & $\begin{array}{c}-0.103^{* * *} \\
(0.031)\end{array}$ & $\begin{array}{c}0.073 \\
(0.052)\end{array}$ & $\begin{array}{c}0.075^{* *} \\
(0.032)\end{array}$ \\
\hline Q3: Addressing underperf $\times$ Tax Rate & $\begin{array}{l}-0.027 \\
(0.022)\end{array}$ & $\begin{array}{l}-0.017 \\
(0.022)\end{array}$ & $\begin{array}{l}-0.033 \\
(0.024)\end{array}$ & $\begin{array}{l}-0.028 \\
(0.026)\end{array}$ & $\begin{array}{c}-0.019 \\
(0.051)\end{array}$ & $\begin{array}{l}-0.014 \\
(0.029)\end{array}$ \\
\hline Q4: Promotions $\times$ Tax Rate & $\begin{array}{r}-0.041^{*} \\
(0.023)\end{array}$ & $\begin{array}{l}-0.038^{*} \\
(0.023)\end{array}$ & $\begin{array}{c}-0.094^{* * *} \\
(0.026)\end{array}$ & $\begin{array}{c}-0.084^{* * *} \\
(0.028)\end{array}$ & $\begin{array}{c}0.109^{* *} \\
(0.046)\end{array}$ & $\begin{array}{c}0.023 \\
(0.032)\end{array}$ \\
\hline Q5: Distinctive workplace $\times$ Tax Rate & $\begin{array}{c}-0.069^{* * *} \\
(0.022)\end{array}$ & $\begin{array}{c}-0.073^{* * *} \\
(0.022)\end{array}$ & $\begin{array}{c}-0.116^{* * *} \\
(0.024)\end{array}$ & $\begin{array}{c}-0.097^{* * *} \\
(0.027)\end{array}$ & $\begin{array}{l}-0.013 \\
(0.051)\end{array}$ & $\begin{array}{c}0.008 \\
(0.029)\end{array}$ \\
\hline Q6: Talent retention $\times$ Tax Rate & $\begin{array}{c}0.007 \\
(0.024)\end{array}$ & $\begin{array}{c}0.006 \\
(0.024)\end{array}$ & $\begin{array}{c}-0.046^{*} \\
(0.026)\end{array}$ & $\begin{array}{c}-0.066^{* *} \\
(0.030)\end{array}$ & $\begin{array}{c}0.209^{* * *} \\
(0.062)\end{array}$ & $\begin{array}{c}0.061^{* *} \\
(0.031)\end{array}$ \\
\hline Observations & 16053 & 16053 & 11756 & 6728 & 4297 & 8467 \\
\hline \# firms & 1781 & 1781 & 1262 & 1511 & 519 & 1588 \\
\hline Dependent Variable Mean & 0.058 & 0.058 & 0.063 & 0.122 & 0.044 & 0.017 \\
\hline Bonus size $\times$ Tax Rate & $\begin{array}{c}-0.415^{* * *} \\
(0.158)\end{array}$ & $\begin{array}{c}-0.472^{* * *} \\
(0.161)\end{array}$ & $\begin{array}{c}-0.311^{*} \\
(0.177)\end{array}$ & $\begin{array}{l}-0.236 \\
(0.207)\end{array}$ & $\begin{array}{c}-1.915^{* * *} \\
(0.384)\end{array}$ & $\begin{array}{l}-0.127 \\
(0.202)\end{array}$ \\
\hline Bonus share: sub perf $\times$ Tax Rate & $\begin{array}{l}-0.146 \\
(0.151)\end{array}$ & $\begin{array}{l}-0.137 \\
(0.150)\end{array}$ & $\begin{array}{l}-0.022 \\
(0.166)\end{array}$ & $\begin{array}{c}0.074 \\
(0.235)\end{array}$ & $\begin{array}{c}-0.681^{*} \\
(0.353)\end{array}$ & $\begin{array}{l}-0.270 \\
(0.173)\end{array}$ \\
\hline Bonus share: MNE perf $\times$ Tax Rate & $\begin{array}{c}-0.321^{* * *} \\
(0.090)\end{array}$ & $\begin{array}{c}-0.304^{* * *} \\
(0.090)\end{array}$ & $\begin{array}{c}-0.237^{* *} \\
(0.109)\end{array}$ & $\begin{array}{c}-0.266^{* * *} \\
(0.091)\end{array}$ & $\begin{array}{l}-0.297 \\
(0.221)\end{array}$ & $\begin{array}{c}-0.098 \\
(0.140)\end{array}$ \\
\hline Observations & 8112 & 8112 & 6048 & 3428 & 2064 & 4139 \\
\hline \# firms & 894 & 894 & 649 & 761 & 245 & 793 \\
\hline Dependent Variable Mean & 0.060 & 0.060 & 0.067 & 0.128 & 0.038 & 0.017 \\
\hline Aggressive measure & & & Tax Haven & BTD & Tax Haven & BTD \\
\hline Country FE & $\checkmark$ & $\checkmark$ & $\checkmark$ & $\checkmark$ & $\checkmark$ & $\checkmark$ \\
\hline Year FE & $\checkmark$ & $\checkmark$ & $\checkmark$ & $\checkmark$ & $\checkmark$ & $\checkmark$ \\
\hline Firm controls & & $\checkmark$ & $\checkmark$ & $\checkmark$ & $\checkmark$ & $\checkmark$ \\
\hline
\end{tabular}

Note: Data from Orbis and the World Management Survey. Tax rate is the statutory corporate tax rate in the country where a firm is operating. The definition of each management practice is in Table C1. The outcome variable in all columns is ROA (returns on assets) which is the ratio of profit and loss before taxes and total assets. In columns 3 and 4 aggressive firms are those with tax haven as part of their ownership structure or those with above median book tax difference (BTD) respectively. In columns 5 and 6 non-aggressive firms are those without tax havens as part of their ownership structure or those with below median book tax difference (BTD) respectively. Firm controls include log of employment, log of fixed assets and log of number of subsidiaries in the MNE. Standard errors are robust in all columns. 
Figure B3: Mechanisms: Management Practices and Firm Productivity for Aggressive and Non-aggressive Firms.
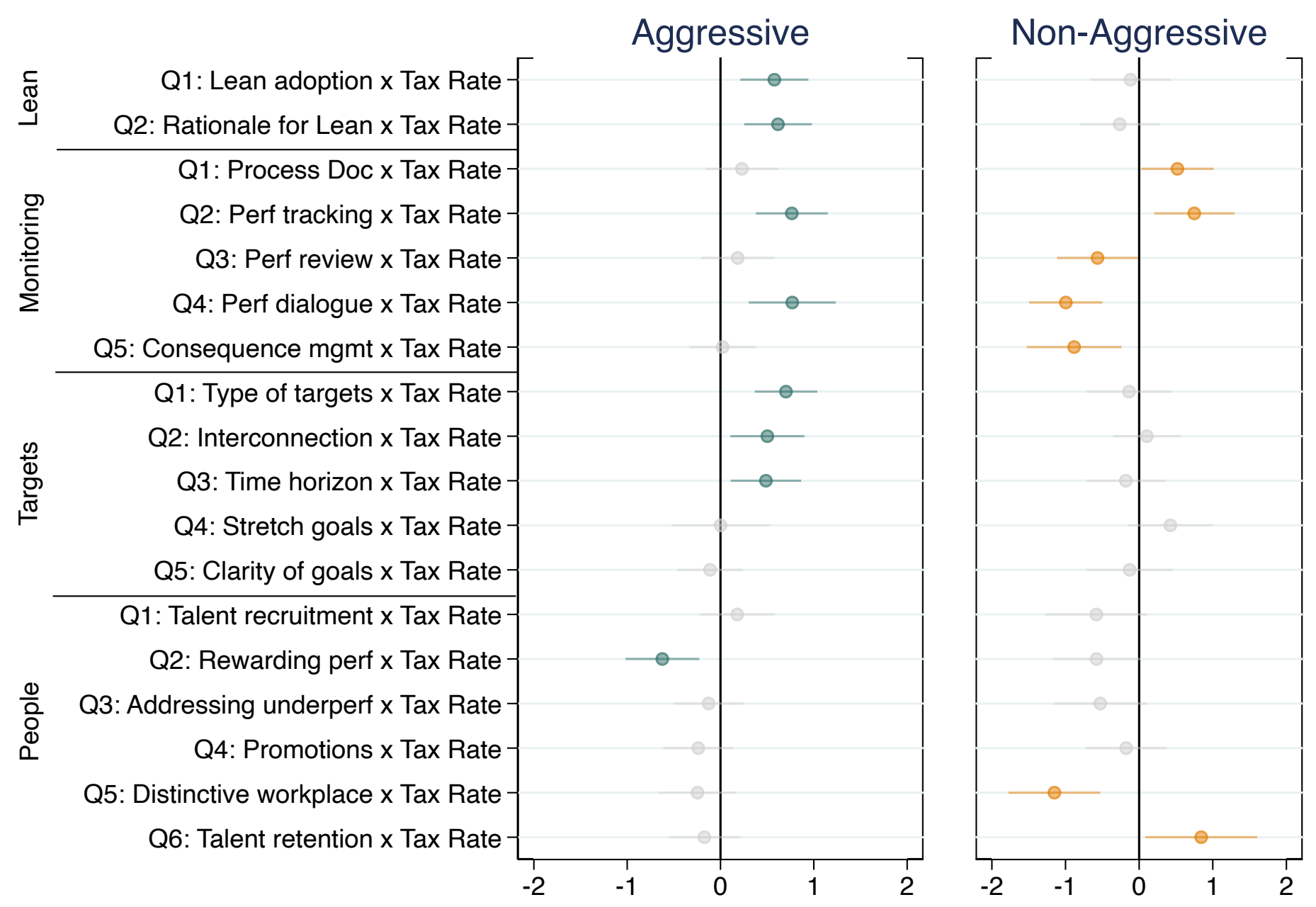

Note: Data from the World Management Survey and Orbis. This figure plots the interaction coefficients from a regression of performance ( $\log$ of sales per employee) on each of the 18 individual management topics, subsidiary corporate tax rates and controls for firm size (log of fixed assets, log of employment, log of number of subsidiaries) as well as year and industry fixed effects. We classify firms as "aggressive" if they have a subsidiary in a tax haven. Darker color markers indicate statistically significant coefficients (at the 5 percent level), and light gray markers indicate coefficients that are not significantly different from zero (at the 5 percent level). 
Table B6: Table of Coefficients: Interaction Between Individual Management Practices and Tax Rate.

\begin{tabular}{|c|c|c|c|c|c|c|}
\hline & \multicolumn{2}{|c|}{ All } & \multicolumn{2}{|c|}{ Aggressive } & \multicolumn{2}{|c|}{ Non-Aggressive } \\
\hline & \multicolumn{2}{|c|}{$\overline{\ln (\text { sales per employee })}$} & \multicolumn{2}{|c|}{$\overline{\ln (\text { sales per employee })}$} & \multicolumn{2}{|c|}{$\ln ($ sales per employee $)$} \\
\hline & (1) & $(2)$ & $(3)$ & (4) & $(5)$ & $(6)$ \\
\hline Z-Index: Lean ops $\times$ Tax Rate & $\begin{array}{c}0.749^{* * *} \\
(0.216)\end{array}$ & $\begin{array}{c}0.547^{* * * *} \\
(0.170)\end{array}$ & $\begin{array}{c}0.663^{* * *} \\
(0.194)\end{array}$ & $\begin{array}{l}-0.101 \\
(0.217)\end{array}$ & $\begin{array}{l}-0.248 \\
(0.299)\end{array}$ & $\begin{array}{c}1.240^{* * *} \\
(0.261)\end{array}$ \\
\hline Q1: Lean adoption $\times$ Tax Rate & $\begin{array}{c}0.560^{* * *} \\
(0.206)\end{array}$ & $\begin{array}{c}0.480^{* * *} \\
(0.162)\end{array}$ & $\begin{array}{c}0.577^{* * *} \\
(0.186)\end{array}$ & $\begin{array}{l}-0.080 \\
(0.214)\end{array}$ & $\begin{array}{l}-0.117 \\
(0.278)\end{array}$ & $\begin{array}{c}1.129^{* * *} \\
(0.236)\end{array}$ \\
\hline Q2: Rationale for Lean $\times$ Tax Rate & $\begin{array}{c}0.762^{* * *} \\
(0.202)\end{array}$ & $\begin{array}{c}0.480^{* * *} \\
(0.161)\end{array}$ & $\begin{array}{c}0.616^{* * *} \\
(0.185)\end{array}$ & $\begin{array}{l}-0.101 \\
(0.200)\end{array}$ & $\begin{array}{l}-0.264 \\
(0.275)\end{array}$ & $\begin{array}{c}1.055^{* * *} \\
(0.257)\end{array}$ \\
\hline Z-Index: Monitoring $\times$ Tax Rate & $\begin{array}{l}0.373^{*} \\
(0.216)\end{array}$ & $\begin{array}{c}0.493^{* * *} \\
(0.178)\end{array}$ & $\begin{array}{c}0.492^{* *} \\
(0.207)\end{array}$ & $\begin{array}{c}0.113 \\
(0.229)\end{array}$ & $\begin{array}{l}-0.392 \\
(0.269)\end{array}$ & $\begin{array}{c}0.794^{* * *} \\
(0.261)\end{array}$ \\
\hline Q1: Process Doc $\times$ Tax Rate & $\begin{array}{c}0.182 \\
(0.201)\end{array}$ & $\begin{array}{c}0.418^{* *} \\
(0.167)\end{array}$ & $\begin{array}{l}0.230 \\
(0.198)\end{array}$ & $\begin{array}{c}0.017 \\
(0.227)\end{array}$ & $\begin{array}{c}0.520^{* *} \\
(0.251)\end{array}$ & $\begin{array}{c}0.742^{* * *} \\
(0.234)\end{array}$ \\
\hline Q2: Perf tracking $\times$ Tax Rate & $\begin{array}{c}0.737^{* * *} \\
(0.208)\end{array}$ & $\begin{array}{c}0.854^{* * *} \\
(0.169)\end{array}$ & $\begin{array}{c}0.764^{* * *} \\
(0.197)\end{array}$ & $\begin{array}{l}0.267 \\
(0.208)\end{array}$ & $\begin{array}{c}0.749^{* * *} \\
(0.278)\end{array}$ & $\begin{array}{c}1.139^{* * *} \\
(0.249)\end{array}$ \\
\hline Q3: Perf review $\times$ Tax Rate & $\begin{array}{c}0.075 \\
(0.210)\end{array}$ & $\begin{array}{c}0.164 \\
(0.170)\end{array}$ & $\begin{array}{c}0.184 \\
(0.200)\end{array}$ & $\begin{array}{l}-0.162 \\
(0.211)\end{array}$ & $\begin{array}{c}-0.565^{* *} \\
(0.281)\end{array}$ & $\begin{array}{c}0.580^{* *} \\
(0.251)\end{array}$ \\
\hline Q4: Perf dialogue $\times$ Tax Rate & $\begin{array}{r}0.504^{* *} \\
(0.240)\end{array}$ & $\begin{array}{l}0.476^{* *} \\
(0.195)\end{array}$ & $\begin{array}{c}0.769^{* * *} \\
(0.238)\end{array}$ & $\begin{array}{l}0.249 \\
(0.233)\end{array}$ & $\begin{array}{c}-0.996^{* * *} \\
(0.254)\end{array}$ & $\begin{array}{c}0.681^{* *} \\
(0.307)\end{array}$ \\
\hline Q5: Consequence mgmt $\times$ Tax Rate & $\begin{array}{l}-0.101 \\
(0.193)\end{array}$ & $\begin{array}{l}-0.029 \\
(0.157)\end{array}$ & $\begin{array}{c}0.023 \\
(0.182)\end{array}$ & $\begin{array}{c}0.010 \\
(0.206)\end{array}$ & $\begin{array}{c}-0.883^{* * *} \\
(0.328)\end{array}$ & $\begin{array}{l}-0.042 \\
(0.221)\end{array}$ \\
\hline Z-Index: Targets $\times$ Tax Rate & $\begin{array}{c}0.804^{* * *} \\
(0.245)\end{array}$ & $\begin{array}{c}0.652^{* * *} \\
(0.203)\end{array}$ & $\begin{array}{c}0.638^{* * *} \\
(0.238)\end{array}$ & $\begin{array}{c}0.262 \\
(0.244)\end{array}$ & $\begin{array}{c}0.224 \\
(0.301)\end{array}$ & $\begin{array}{c}1.165^{* * *} \\
(0.310)\end{array}$ \\
\hline Q1: Type of targets $\times$ Tax Rate & $\begin{array}{c}0.922^{* * *} \\
(0.188)\end{array}$ & $\begin{array}{c}0.582^{* * * *} \\
(0.153)\end{array}$ & $\begin{array}{c}0.702^{* * *} \\
(0.171)\end{array}$ & $\begin{array}{c}0.191 \\
(0.208)\end{array}$ & $\begin{array}{l}-0.137 \\
(0.296)\end{array}$ & $\begin{array}{c}0.845^{* * *} \\
(0.210)\end{array}$ \\
\hline Q2: Interconnection $\times$ Tax Rate & $\begin{array}{c}0.757^{* * *} \\
(0.208)\end{array}$ & $\begin{array}{c}0.571^{* * *} \\
(0.169)\end{array}$ & $\begin{array}{c}0.502^{* *} \\
(0.202)\end{array}$ & $\begin{array}{c}0.282 \\
(0.216)\end{array}$ & $\begin{array}{c}0.104 \\
(0.234)\end{array}$ & $\begin{array}{c}0.963^{* * *} \\
(0.243)\end{array}$ \\
\hline Q3: Time horizon $\times$ Tax Rate & $\begin{array}{c}0.553^{* * *} \\
(0.203)\end{array}$ & $\begin{array}{c}0.429^{* *} \\
(0.168)\end{array}$ & $\begin{array}{r}0.487^{* *} \\
(0.193)\end{array}$ & $\begin{array}{c}0.151 \\
(0.213)\end{array}$ & $\begin{array}{l}-0.180 \\
(0.274)\end{array}$ & $\begin{array}{c}0.830^{* * *} \\
(0.252)\end{array}$ \\
\hline Q4: Stretch goals $\times$ Tax Rate & $\begin{array}{l}-0.266 \\
(0.257)\end{array}$ & $\begin{array}{c}0.183 \\
(0.216)\end{array}$ & $\begin{array}{c}0.001 \\
(0.266)\end{array}$ & $\begin{array}{c}0.230 \\
(0.242)\end{array}$ & $\begin{array}{c}0.425 \\
(0.294)\end{array}$ & $\begin{array}{c}0.321 \\
(0.350)\end{array}$ \\
\hline Q5: Clarity of goals $\times$ Tax Rate & $\begin{array}{l}-0.021 \\
(0.192)\end{array}$ & $\begin{array}{l}-0.118 \\
(0.155)\end{array}$ & $\begin{array}{l}-0.112 \\
(0.179)\end{array}$ & $\begin{array}{l}-0.315 \\
(0.206)\end{array}$ & $\begin{array}{l}-0.128 \\
(0.298)\end{array}$ & $\begin{array}{c}0.141 \\
(0.219)\end{array}$ \\
\hline Observations & 15601 & 15601 & 11394 & 6600 & 4207 & 8275 \\
\hline \# firms & 1757 & 1757 & 1246 & 1494 & 511 & 1570 \\
\hline Dependent Variable Mean & 12.370 & 12.370 & 12.400 & 12.416 & 12.288 & 12.377 \\
\hline Aggressive measure & & & Tax Haven & BTD & Tax Haven & BTD \\
\hline Country FE & $\checkmark$ & $\checkmark$ & $\checkmark$ & $\checkmark$ & $\checkmark$ & $\checkmark$ \\
\hline Year FE & $\checkmark$ & $\checkmark$ & $\checkmark$ & $\checkmark$ & $\checkmark$ & $\checkmark$ \\
\hline Firm controls & & $\checkmark$ & $\checkmark$ & $\checkmark$ & $\checkmark$ & $\checkmark$ \\
\hline
\end{tabular}

Note: Data from Orbis and the World Management Survey. Tax rate is the statutory corporate tax rate in the country where a firm is operating. The definition of each management practice is in Table C1. The outcome variable in all columns is ROA (returns on assets) which is the ratio of profit and loss before taxes and total assets. In columns 3 and 4 aggressive firms are those with tax haven as part of their ownership structure or those with above median fosok tax difference (BTD) respectively. In columns 5 and 6 non-aggressive firms are those without tax havens as part of their ownership structure or those with below median book tax difference (BTD) respectively. Firm controls include log of employment, log of fixed assets and log of number of subsidiaries in the MNE. Standard errors are robust in all columns. 
Table B7: Table of Coefficients: Interaction Between Individual Management Practices and Tax Rate.

\begin{tabular}{|c|c|c|c|c|c|c|}
\hline & \multicolumn{2}{|c|}{ All } & \multicolumn{2}{|c|}{ Aggressive } & \multicolumn{2}{|c|}{ Non-Aggressive } \\
\hline & \multicolumn{2}{|c|}{$\ln ($ sales per employee $)$} & \multicolumn{2}{|c|}{$\ln ($ sales per employee) } & \multicolumn{2}{|c|}{$\overline{\ln (\text { sales per employee })}$} \\
\hline & (1) & $(2)$ & (3) & (4) & $(5)$ & (6) \\
\hline \multirow[t]{2}{*}{ Z-Index: People $\times$ Tax Rate } & -0.074 & 0.133 & 0.167 & -0.085 & $-0.637^{* *}$ & $0.447^{*}$ \\
\hline & $(0.196)$ & $(0.160)$ & $(0.188)$ & $(0.214)$ & $(0.260)$ & $(0.231)$ \\
\hline \multirow{2}{*}{ Q1: Talent recruitment $\times$ Tax Rate } & 0.058 & 0.080 & 0.178 & -0.111 & $-0.662^{* *}$ & $0.488^{* *}$ \\
\hline & $(0.201)$ & $(0.159)$ & $(0.183)$ & $(0.205)$ & $(0.303)$ & $(0.222)$ \\
\hline \multirow[t]{2}{*}{ Q2: Rewarding perf $\times$ Tax Rate } & -0.190 & -0.190 & -0.142 & $-0.613^{* * *}$ & $-0.478^{*}$ & 0.035 \\
\hline & $(0.182)$ & $(0.154)$ & $(0.185)$ & $(0.204)$ & $(0.284)$ & $(0.204)$ \\
\hline \multirow[t]{2}{*}{ Q3: Addressing underperf $\times$ Tax Rate } & 0.107 & -0.019 & -0.033 & 0.294 & $-0.637^{* *}$ & $-0.414^{* *}$ \\
\hline & $(0.175)$ & $(0.144)$ & $(0.167)$ & $(0.189)$ & $(0.251)$ & $(0.205)$ \\
\hline \multirow[t]{2}{*}{ Q4: Promotions $\times$ Tax Rate } & $-0.318^{*}$ & -0.125 & -0.033 & $-0.380^{*}$ & $-0.678^{* * *}$ & 0.185 \\
\hline & $(0.185)$ & $(0.153)$ & $(0.181)$ & $(0.202)$ & $(0.259)$ & $(0.218)$ \\
\hline \multirow[t]{2}{*}{ Q5: Distinctive workplace $\times$ Tax Rate } & $-0.400^{*}$ & -0.020 & -0.017 & -0.152 & $-0.665^{* *}$ & $0.553^{* *}$ \\
\hline & $(0.216)$ & $(0.169)$ & $(0.197)$ & $(0.224)$ & $(0.291)$ & $(0.241)$ \\
\hline \multirow[t]{2}{*}{ Q6: Talent retention $\times$ Tax Rate } & 0.047 & $0.488^{* * *}$ & $0.385^{* *}$ & 0.181 & $0.987^{* * *}$ & $0.682^{* * *}$ \\
\hline & $(0.186)$ & $(0.152)$ & $(0.170)$ & $(0.193)$ & $(0.367)$ & $(0.212)$ \\
\hline Observations & 15597 & 15597 & 11398 & 6591 & 4199 & 8277 \\
\hline \# firms & 1757 & 1757 & 1247 & 1493 & 510 & 1570 \\
\hline Dependent Variable Mean & 12.369 & 12.369 & 12.400 & 12.415 & 12.287 & 12.377 \\
\hline \multirow[t]{2}{*}{ Bonus size $\times$ Tax Rate } & 1.677 & 0.929 & 0.800 & -0.314 & 0.128 & $3.041^{* *}$ \\
\hline & $(1.468)$ & $(0.960)$ & $(1.037)$ & $(1.310)$ & $(2.341)$ & $(1.391)$ \\
\hline \multirow[t]{2}{*}{ Bonus share: sub perf $\times$ Tax Rate } & $-3.783^{* * *}$ & $-3.068^{* * *}$ & $-3.802^{* * *}$ & -0.170 & -2.930 & $-3.068^{* *}$ \\
\hline & $(1.168)$ & $(0.995)$ & $(1.154)$ & $(1.570)$ & $(2.800)$ & $(1.259)$ \\
\hline \multirow[t]{2}{*}{ Bonus share: MNE perf $\times$ Tax Rate } & -0.986 & $-1.055^{*}$ & $-2.258^{* * *}$ & $-1.329^{*}$ & 1.650 & 0.328 \\
\hline & $(0.755)$ & $(0.592)$ & $(0.726)$ & $(0.733)$ & $(1.073)$ & $(0.978)$ \\
\hline Observations & 7803 & 7803 & 5813 & 3327 & 1990 & 4021 \\
\hline \# firms & 877 & 877 & 638 & 751 & 239 & 780 \\
\hline Dependent Variable Mean & 12.336 & 12.336 & 12.349 & 12.393 & 12.298 & 12.347 \\
\hline Aggressive measure & & & Tax Haven & BTD & Tax Haven & BTD \\
\hline Country FE & $\checkmark$ & $\checkmark$ & $\checkmark$ & $\checkmark$ & $\checkmark$ & $\checkmark$ \\
\hline Year FE & $\checkmark$ & $\checkmark$ & $\checkmark$ & $\checkmark$ & $\checkmark$ & $\checkmark$ \\
\hline Firm controls & & $\checkmark$ & $\checkmark$ & $\checkmark$ & $\checkmark$ & $\checkmark$ \\
\hline
\end{tabular}

Note: Data from Orbis and the World Management Survey. Tax rate is the statutory corporate tax rate in the country where a firm is operating. The definition of each management practice is in Table C1. The outcome variable in all columns is ROA (returns on assets) which is the ratio of profit and loss before taxes and total assets. In columns 3 and 4 aggressive firms are those with tax haven as part of their ownership structure or those with above median book tax difference (BTD) respectively. In columns 5 and 6 non-aggressive firms are those without tax havens as part of their ownership structure or those with below median book tax difference (BTD) respectively. Firm controls include log of employment, log of fixed assets and log of number of subsidiaries in the MNE. Standard errors are robust in all columns. 
Figure B4: Bunching of ROA around Zero for Firms in Tax Havens by Management Type.

(a) Aggressive

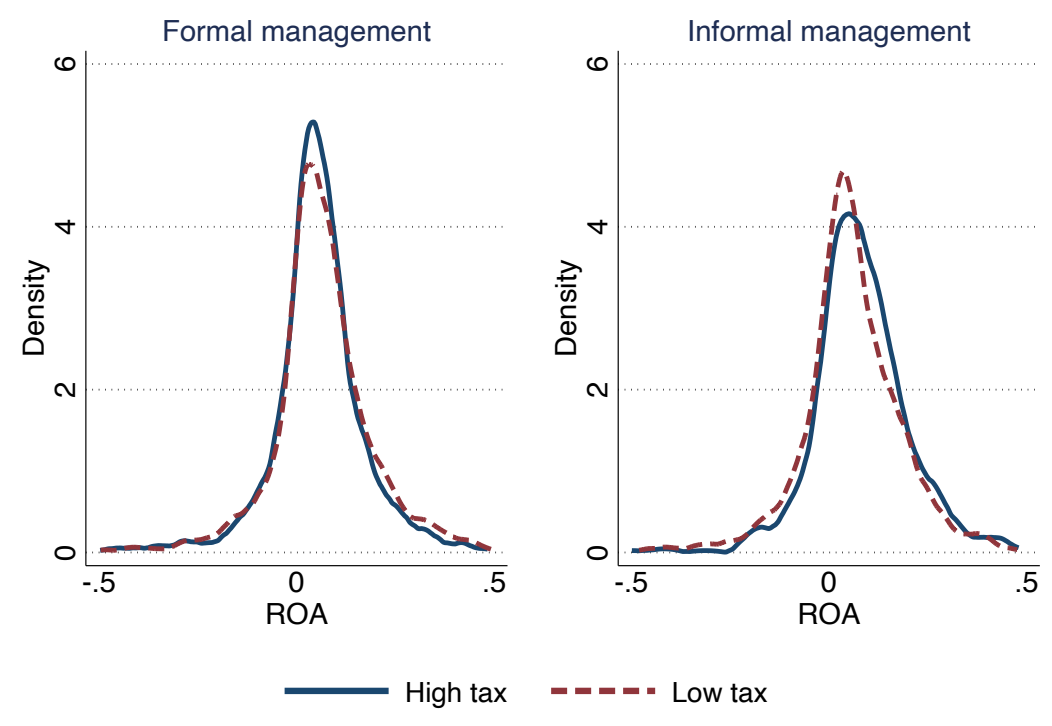

(b) Non-aggressive

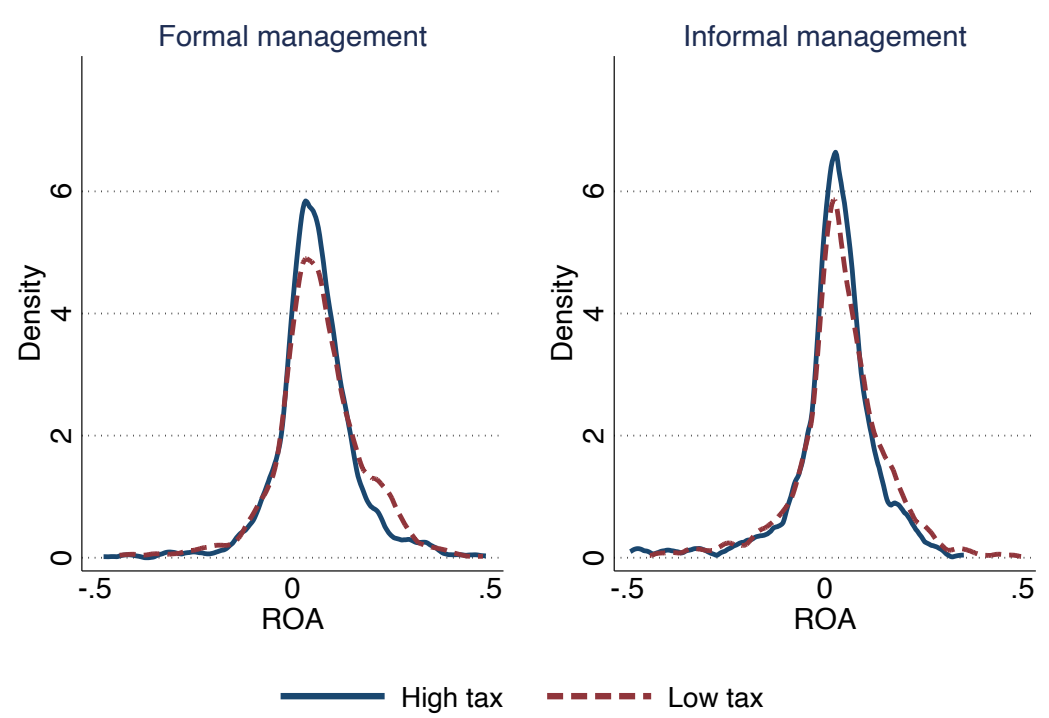

Note: Data from the World Management Survey and Orbis. Static sample includes only firms that for which we observe management scores and were directly matched in both WMS and Orbis. We plot the distribution of ROA, which is the ratio of profit and loss to total assets. ROA restricted between -1 and 1 . Structured management is a dummy equal to one when the average for the WMS operations management questions (including lean management, monitoring and target-setting) is 3 or above, on a scale of 5 . High tax is a dummy equal to 1 when the firm is located in a country with above median statutory corporate tax rate. Hence, blue solid lines show the distribution of ROA for subsidiaries in high tax countries, while red dashed lines for subsidiaries in low tax countries. In Panel A we show the ROA distributions for aggressive firms and in Panel B for non-aggressive. Non-aggressive are firms that have no subsidiary or headquarters located in a tax-haven and Aggressive are firms that have at least one subsidiary or headquarter located in a tax haven. Out of 1325 MNEs, $50.61 \%$ have at least one subsidiary in a tax haven. 
Figure B5: Sample Coverage Maps.

(a) Countries with at least one firm in the WMS sample

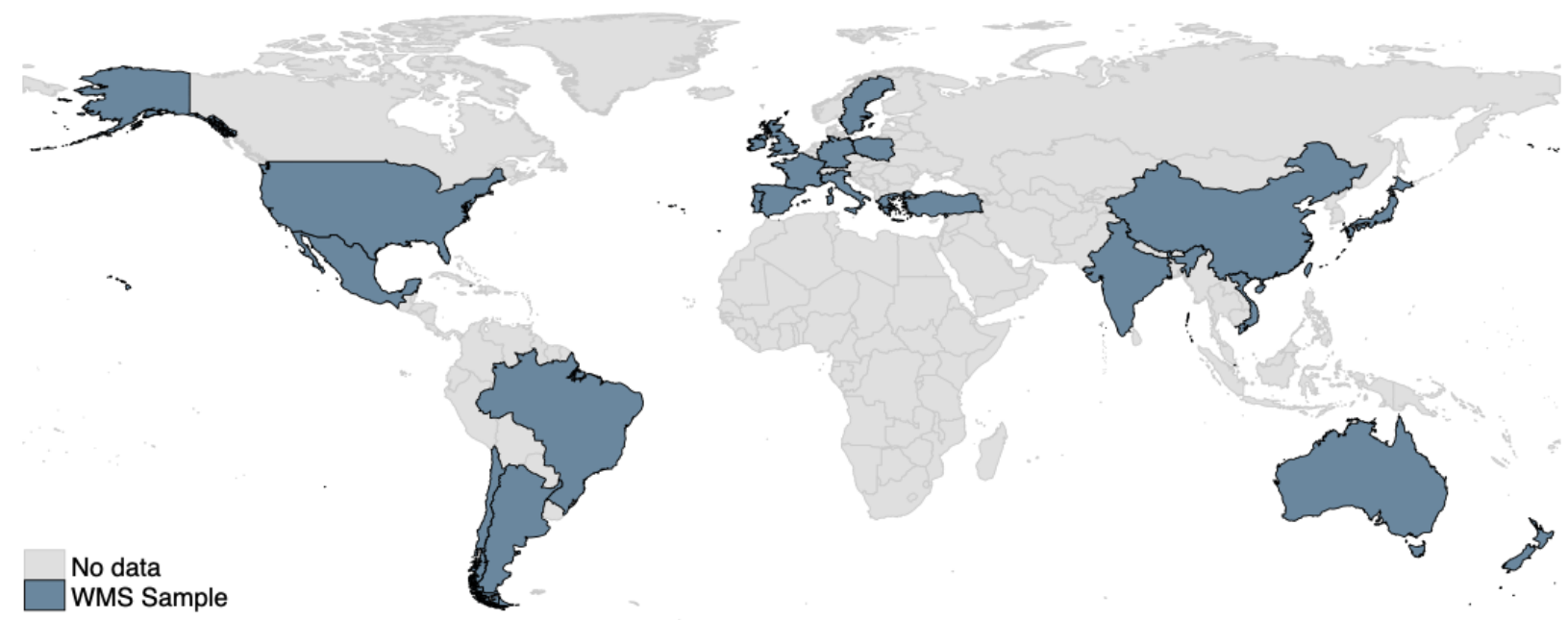

(b) Countries with at least one firm in the Event Study sample

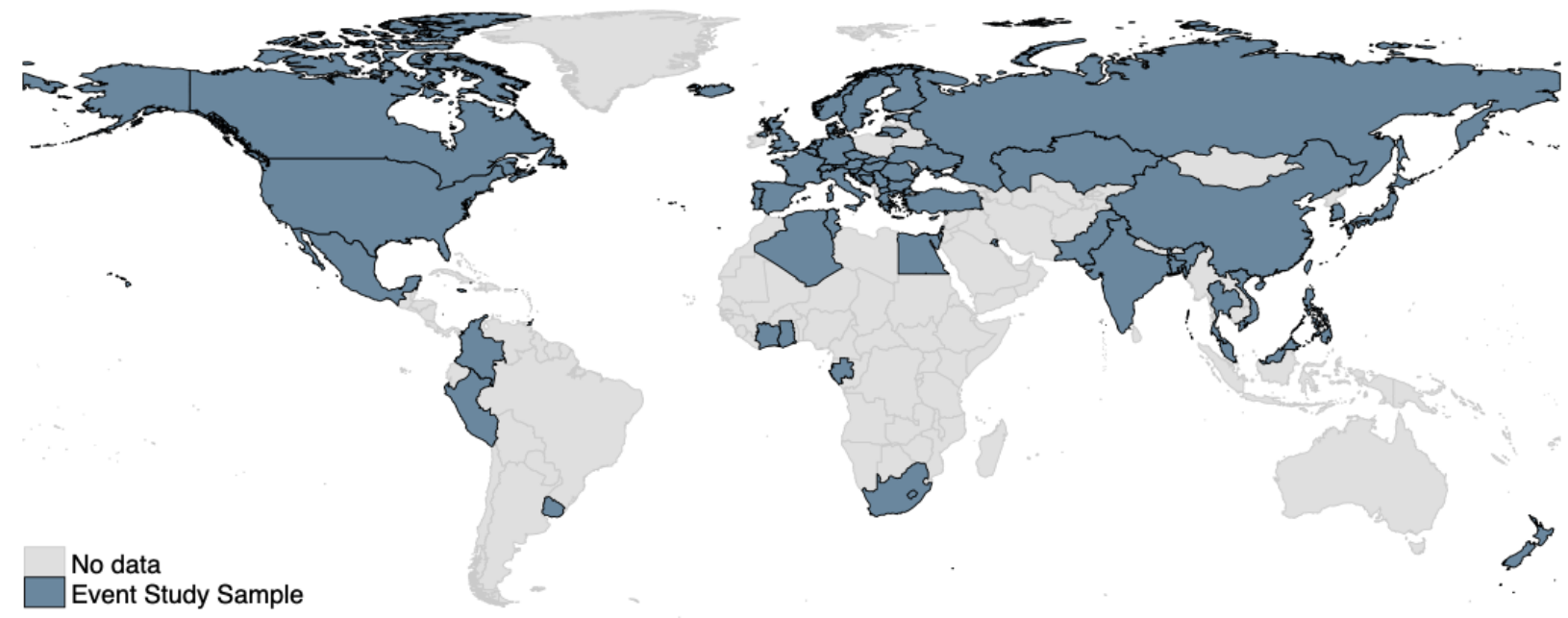


Figure B6: Event Study Sensitivity Analysis.

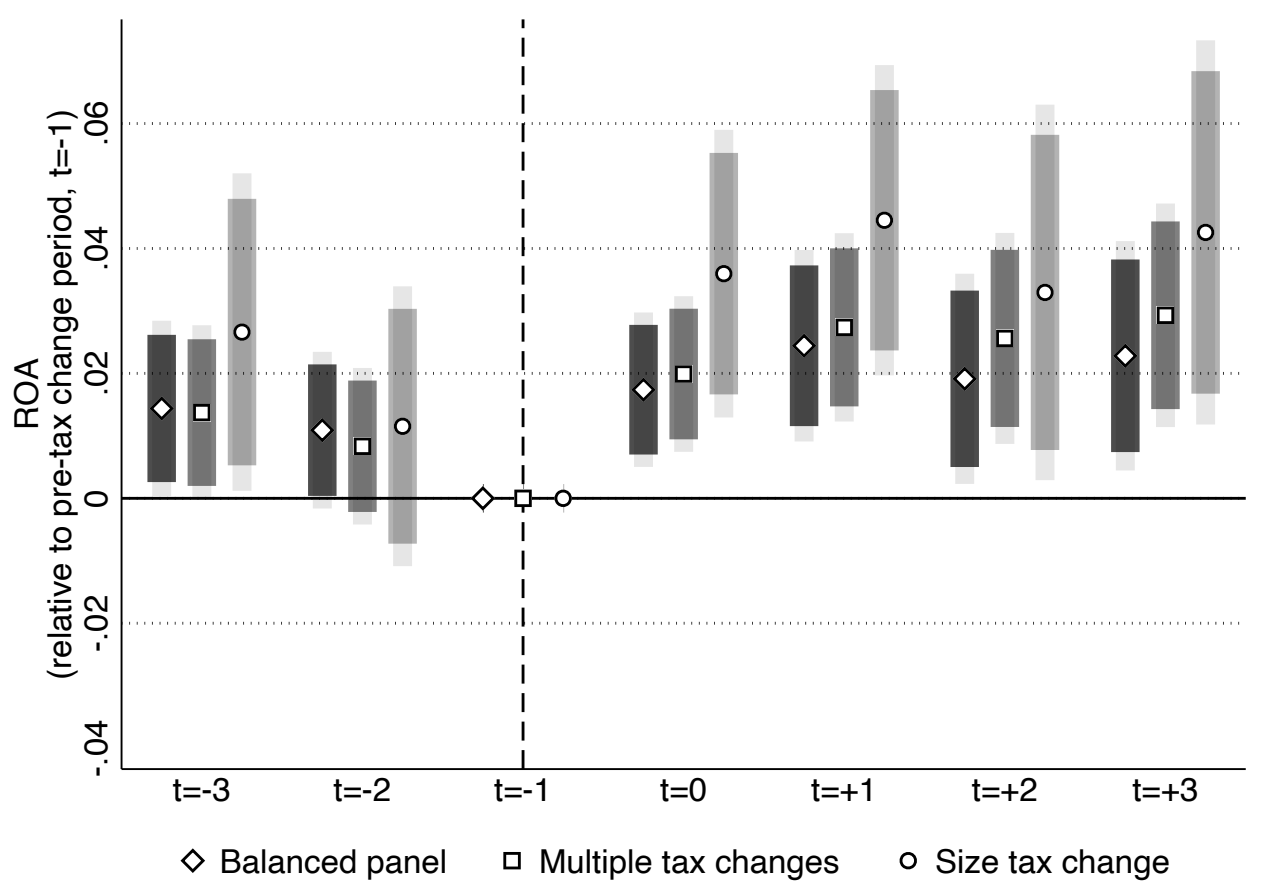

Note: Data from the World Management Survey and Orbis. In this figure we plot yearly coefficients from event study estimation of the difference between formal and informal management firms. Darker bars with diamond markers correspond to the event study run only on the observations belonging to a balanced panel. Mid-dark bars with square uses a sample that includes multiple tax changes. Lighter bars with circle markers include controls for the size of the tax change. 
C Data Appendix: Index questions 
Table C1: World Management Survey Questions: Operations management

\begin{tabular}{|c|c|c|}
\hline $\mathrm{Q}$ & Question topic & Explanation of scoring \\
\hline O1 & $\begin{array}{l}\text { Adoption of modern practices } \\
\text { (Lean operations sub-index) }\end{array}$ & $\begin{array}{l}\text { What aspects of manufacturing have been formally in- } \\
\text { troduced, including just-in-time delivery from suppliers, } \\
\text { automation, flexible manpower, support systems, atti- } \\
\text { tudes, and behavior? }\end{array}$ \\
\hline $\mathrm{O} 2$ & $\begin{array}{l}\text { Rationale for adoption } \\
\text { (Lean operations sub-index) }\end{array}$ & $\begin{array}{l}\text { Were modern manufacturing techniques adopted just be- } \\
\text { cause others were using them, or are they linked to meet- } \\
\text { ing business objectives like reducing costs and improving } \\
\text { quality? }\end{array}$ \\
\hline O3 & $\begin{array}{l}\text { Process problem } \\
\text { documentation (Monitoring } \\
\text { sub-index) }\end{array}$ & $\begin{array}{l}\text { Are process improvements made only when problems } \\
\text { arise, or are they actively sought out for continuous im- } \\
\text { provement as part of normal business processes? }\end{array}$ \\
\hline $\mathrm{O} 4$ & $\begin{array}{l}\text { Performance tracking } \\
\text { (Monitoring sub-index) }\end{array}$ & $\begin{array}{l}\text { Is tracking ad hoc and incomplete, or is performance } \\
\text { continually tracked and communicated to all staff? }\end{array}$ \\
\hline O5 & $\begin{array}{l}\text { Performance review } \\
\text { (Monitoring sub-index) }\end{array}$ & $\begin{array}{l}\text { Is performance reviewed infrequently and only on a suc- } \\
\text { cess/failure scale, or is performance reviewed continually } \\
\text { with an expectation of continuous improvement? }\end{array}$ \\
\hline O6 & $\begin{array}{l}\text { Performance dialogue } \\
\text { (Monitoring sub-index) }\end{array}$ & $\begin{array}{l}\text { In review/performance conversations, to what extent are } \\
\text { the purpose, data, agenda, and follow-up steps (like } \\
\text { coaching) clear to all parties? }\end{array}$ \\
\hline $\mathrm{O} 7$ & $\begin{array}{l}\text { Consequence management } \\
\text { (Monitoring sub-index) }\end{array}$ & $\begin{array}{l}\text { To what extent does failure to achieve agreed objectives } \\
\text { carry consequences, which can include retraining or re- } \\
\text { assignment to other jobs? }\end{array}$ \\
\hline O8 & $\begin{array}{l}\text { Target balance } \\
\text { (Target setting sub-index) }\end{array}$ & $\begin{array}{l}\text { Are the goals exclusively financial, or is there a balance } \\
\text { of financial and non-financial targets? }\end{array}$ \\
\hline O9 & $\begin{array}{l}\text { Target interconnection } \\
\text { (Target setting sub-index) }\end{array}$ & $\begin{array}{l}\text { Are goals based on accounting value, or are they based on } \\
\text { shareholder value in a way that works through business } \\
\text { units and ultimately is connected to individual perfor- } \\
\text { mance expectations? }\end{array}$ \\
\hline & $\begin{array}{l}0 \text { Target time horizon } \\
\text { (Target setting sub-index) }\end{array}$ & $\begin{array}{l}\text { Does top management focus mainly on the short term, } \\
\text { or does it visualize short-term targets as a "staircase" } \\
\text { toward the main focus on long-term goals? }\end{array}$ \\
\hline & $\begin{array}{l}1 \text { Target stretching } \\
\text { (Target setting sub-index) }\end{array}$ & $\begin{array}{l}\text { Are goals too easy to achieve, especially for some "pro- } \\
\text { tected/special" areas of the firm, or are goals demanding } \\
\text { but attainable for all parts of the firm? }\end{array}$ \\
\hline & $\begin{array}{l}2 \text { Performance clarity } \\
\text { (Target setting sub-index) }\end{array}$ & $\begin{array}{l}\text { Are performance measures ill-defined, poorly under- } \\
\text { stood, and private, or are they well-defined, clearly com- } \\
\text { municated, and made public? }\end{array}$ \\
\hline
\end{tabular}

Notes: Table contents from Scur et al. (2021). The Q column refers to the question numbers as we have defined the indices in this paper (operations and people management). The main difference between our categorization and the WMS is that we bundle the operations sub-practices into one, so we can effectively compare people and non-people practices. The last column includes a more detailed explanation of the types of follow-up questions that are asked of the manager to garner the information required for scoring. 
Table C2: World Management Survey Questions: People management

\begin{tabular}{|c|c|c|}
\hline $\mathrm{Q}$ & Question topic & Explanation of scoring \\
\hline $\mathrm{P} 1$ & $\begin{array}{l}\text { Managing human capital } \\
\text { (People management } \\
\text { sub-index, survey Q13) }\end{array}$ & $\begin{array}{l}\text { To what extent are senior managers evaluated and held } \\
\text { accountable for attracting, retaining, and developing tal- } \\
\text { ent throughout the organization? }\end{array}$ \\
\hline $\mathrm{P} 2$ & $\begin{array}{l}\text { Rewarding high performance } \\
\text { (People management } \\
\text { sub-index, survey Q14) }\end{array}$ & $\begin{array}{l}\text { To what extent are people in the firm rewarded equally } \\
\text { irrespective of performance level, or is performance } \\
\text { clearly related to accountability and rewards? }\end{array}$ \\
\hline P3 & $\begin{array}{l}\text { Fixing poor performers } \\
\text { (People management } \\
\text { sub-index, survey Q15) }\end{array}$ & $\begin{array}{l}\text { Are poor performers rarely removed, or are they re- } \\
\text { trained and/or moved into different roles or out of the } \\
\text { company as soon as the weakness is identified? }\end{array}$ \\
\hline $\mathrm{P} 4$ & $\begin{array}{l}\text { Promoting high performers } \\
\text { (People management } \\
\text { sub-index, survey Q16) }\end{array}$ & $\begin{array}{l}\text { Are people promoted mainly on the basis of tenure, or } \\
\text { does the firm actively identify, develop, and promote its } \\
\text { top performers? }\end{array}$ \\
\hline P5 & $\begin{array}{l}\text { Attracting human capital } \\
\text { (People management } \\
\text { sub-index, survey Q17) }\end{array}$ & $\begin{array}{l}\text { Do competitors offer stronger reasons for talented people } \\
\text { to join their companies, or does a firm provide a wide } \\
\text { range of reasons to encourage talented people to join? }\end{array}$ \\
\hline $\mathrm{P} 6$ & $\begin{array}{l}\text { Retaining human capital } \\
\text { (People management } \\
\text { sub-index, survey Q18) }\end{array}$ & $\begin{array}{l}\text { Does the firm do relatively little to retain top talent, or } \\
\text { does it do whatever it takes to retain top talent when } \\
\text { they look likely to leave? }\end{array}$ \\
\hline B1 & $\begin{array}{l}\text { What is a manager's bonus as } \\
\text { a percentage of salary? }\end{array}$ & A value between 0 and 1 . \\
\hline $\mathrm{B} 2$ & $\begin{array}{l}\text { What is the } \% \text { of the bonus } \\
\text { that is based on individual } \\
\text { performance? }\end{array}$ & A value between 0 and 1 . \\
\hline B3 & $\begin{array}{l}\text { What is the \% of the bonus } \\
\text { that is based on company } \\
\text { performance? }\end{array}$ & A value between 0 and 1 . \\
\hline $\mathrm{DC}$ & Decentralization & $\begin{array}{l}\text { Where are decisions taken on new product introduc- } \\
\text { tions-at the plant, at the CHQ or both? How much } \\
\text { of sales and marketing is carried out at the plant level } \\
\text { (rather than at the CHQ)? Score 1: All decisions are } \\
\text { taken at HQ. Score 3: Decisions are jointly determined. } \\
\text { Score 5: All decisions are taken at the plant level. De- } \\
\text { centralization score is the average of the two questions. }\end{array}$ \\
\hline
\end{tabular}

Notes: Table contents from Scur et al. (2021). The Q column refers to the question numbers as we have defined the indices in this paper (operations and people management). The main difference between our categorization and the WMS is that we bundle the operations sub-practices into one, so we can effectively compare people and non-people practices. The last column includes a more detailed explanation of the types of follow-up questions that are asked of the manager to garner the information required for scoring. 
CENTRE FOR ECONOMIC PERFORMANCE

Recent Discussion Papers

\begin{tabular}{|c|c|c|}
\hline 1794 & $\begin{array}{l}\text { Monica Langella } \\
\text { Alan Manning }\end{array}$ & Income and the desire to migrate \\
\hline 1793 & $\begin{array}{l}\text { Nicholas Bloom } \\
\text { Arjun Ramani }\end{array}$ & The donut effect of Covid-19 on cities \\
\hline 1792 & $\begin{array}{l}\text { Brian Bell } \\
\text { Nicholas Bloom } \\
\text { Jack Blundell }\end{array}$ & $\begin{array}{l}\text { This time is not so different: income dynamics } \\
\text { during the Covid-19 recession }\end{array}$ \\
\hline 1791 & $\begin{array}{l}\text { Emanuel Ornelas } \\
\text { Patricia Tovar }\end{array}$ & $\begin{array}{l}\text { Intra-bloc tariffs and preferential margins in } \\
\text { trade agreements }\end{array}$ \\
\hline 1790 & $\begin{array}{l}\text { Jose Maria Barrero } \\
\text { Nicholas Bloom } \\
\text { Steven J. Davis }\end{array}$ & Why working from home will stick \\
\hline 1789 & $\begin{array}{l}\text { Scott R. Baker } \\
\text { Nicholas Bloom } \\
\text { Steven J. Davis } \\
\text { Marco Sammon }\end{array}$ & What triggers stock market jumps? \\
\hline 1788 & $\begin{array}{l}\text { Nicolas Bloom } \\
\text { Robert S. Fletcher } \\
\text { Ethan Yeh }\end{array}$ & The impact of Covid-19 on US firms \\
\hline 1787 & $\begin{array}{l}\text { Philippe Aghion } \\
\text { Antonin Bergeaud } \\
\text { Matthieu Lequien } \\
\text { Marc J. Melitz } \\
\text { Thomas Zuber }\end{array}$ & $\begin{array}{l}\text { Opposing firm-level responses to the China } \\
\text { shock: horizontal competition versus vertical } \\
\text { relationships }\end{array}$ \\
\hline 1786 & $\begin{array}{l}\text { Elsa Leromain } \\
\text { Gonzague Vannoorenberghe }\end{array}$ & $\begin{array}{l}\text { Voting under threat: evidence from the } 2020 \\
\text { French local elections }\end{array}$ \\
\hline 1785 & $\begin{array}{l}\text { Benny Kleinman } \\
\text { Ernest Liu } \\
\text { Stephen J. Redding }\end{array}$ & Dynamic spatial general equilibrium \\
\hline
\end{tabular}




\begin{tabular}{|c|c|c|}
\hline 1784 & $\begin{array}{l}\text { Antonin Bergeaud } \\
\text { Clément Malgouyres } \\
\text { Clément Mazet-Sonilhac } \\
\text { Sara Signorelli }\end{array}$ & $\begin{array}{l}\text { Technological change and domestic } \\
\text { outsourcing }\end{array}$ \\
\hline 1783 & $\begin{array}{l}\text { Facundo Albornoz } \\
\text { Irene Brambilla } \\
\text { Emanuel Ornelas }\end{array}$ & Firm export responses to tariff hikes \\
\hline 1782 & $\begin{array}{l}\text { Gabriel M. Ahlfeldt } \\
\text { Stephan Heblich } \\
\text { Tobias Seidel }\end{array}$ & $\begin{array}{l}\text { Micro-geographic property price and rent } \\
\text { indices }\end{array}$ \\
\hline 1781 & $\begin{array}{l}\text { Ria Ivandić } \\
\text { Tom Kirchmaier } \\
\text { Neus Torres-Blas }\end{array}$ & Football, alcohol and domestic abuse \\
\hline 1780 & $\begin{array}{l}\text { Monica Langella } \\
\text { Alan Manning }\end{array}$ & The measure of monopsony \\
\hline 1779 & $\begin{array}{l}\text { Holger Breinlich } \\
\text { Elsa Leromain } \\
\text { Dennis Novy } \\
\text { Thomas Sampson }\end{array}$ & $\begin{array}{l}\text { Import liberalization as export destruction? } \\
\text { Evidence from the United States }\end{array}$ \\
\hline 1778 & $\begin{array}{l}\text { Andrew E. Clark } \\
\text { Conchita D’Ambrosio } \\
\text { Anthony Lepinteur }\end{array}$ & $\begin{array}{l}\text { Marriage as insurance: job protection and job } \\
\text { insecurity in France }\end{array}$ \\
\hline 1777 & $\begin{array}{l}\text { Marc J. Melitz } \\
\text { Stephen J. Redding }\end{array}$ & Trade and innovation \\
\hline 1776 & $\begin{array}{l}\text { Holger Breinlich } \\
\text { Valentina Corradi } \\
\text { Nadia Rocha } \\
\text { Michele Ruta } \\
\text { J.M.C. Santos Silva } \\
\text { Tom Zylkin }\end{array}$ & $\begin{array}{l}\text { Machine learning in international trade } \\
\text { research - evaluating the impact of trade } \\
\text { agreements }\end{array}$ \\
\hline 1775 & $\begin{array}{l}\text { Giuseppe Berlingieri } \\
\text { Luca Marcolin } \\
\text { Emanuel Ornelas }\end{array}$ & Service offshoring and export experience \\
\hline
\end{tabular}

The Centre for Economic Performance Publications Unit Tel: +44 (0)207955 7673 Email info@cep.lse.ac.uk 
Website: http://cep.lse.ac.uk Twitter: @CEP_LSE 